\title{
Lab-Scale Demonstration of Plutonium Purification by Anion Exchange, Plutonium(IV) Oxalate Precipitation, and Calcination to Plutonium Oxide to Support the MOX Feed Mission
}

M. L. Crowder

R. A. Pierce

August 2012

Savannah River National Laboratory

Savannah River Nuclear Solutions, LLC

Aiken, SC 29808

Prepared for the U.S. Department of Energy under contract number DE-AC09-08SR22470. 
SRNL-STI-2012-00422

Revision 0

\section{DISCLAIMER}

This work was prepared under an agreement with and funded by the U.S. Government. Neither the U.S. Government or its employees, nor any of its contractors, subcontractors or their employees, makes any express or implied:

1. warranty or assumes any legal liability for the accuracy, completeness, or for the use or results of such use of any information, product, or process disclosed; or

2. representation that such use or results of such use would not infringe privately owned rights; or

3. endorsement or recommendation of any specifically identified commercial product, process, or service.

Any views and opinions of authors expressed in this work do not necessarily state or reflect those of the United States Government, or its contractors, or subcontractors.

\section{Printed in the United States of America}

Prepared for

U.S. Department of Energy 
Keywords: anion exchange, plutonium(IV) oxalate precipitation, calcination, moisture, surface area

Retention: Permanent

\section{Lab-Scale Demonstration of Plutonium Purification by Anion Exchange, Plutonium(IV) Oxalate Precipitation, and Calcination to Plutonium Oxide to Support the MOX Feed Mission}

M. L. Crowder

R. A. Pierce

August 2012

Savannah River National Laboratory

Savannah River Nuclear Solutions, LLC

Aiken, SC 29808

Prepared for the U.S. Department of Energy under contract number DE-AC09-08SR22470. 


\section{REVIEWS AND APPROVALS}

AUTHORS:

M. L. Crowder, Separation \& Actinide Science Programs

R. A. Pierce, Separation \& Actinide Science Programs

Date

Date
TECHNICAL REVIEW:

W. D. King, Advanced Characterization \& Processing

Date

J. E. Therrell, Reviewer, HB-Line Engineering

Date

APPROVAL:

S. D. Fink, Manager

Separation \& Actinide Science Programs

Date

S. L. Marra, Manager

Environmental \& Chemical Process Technology Research Programs

\section{Date}

Envirommental \& Chemical Process Technology Research Programs

K. P. Burrows, Manager

Date

HB-Line Engineering 


\section{ACKNOWLEDGEMENTS}

The authors acknowledge excellent analytical support from John Scogin for surface area analysis, David Missimer for particle size analysis, David DiPrete, Cecilia DiPrete and Mira Malek for radiochemical analysis, including method development, Mark Jones for ICP-MS analysis, Boyd Wiedenman for ICP-ES analysis, Tom White for ion chromatograpy analysis, and Amy Ekechukwu for acid analysis.

As lead author, I acknowledge the helpfulness of Jon Duffey and Eddie Kyser in technical discussions and experimental planning. 


\section{EXECUTIVE SUMMARY}

To support the upcoming mission to produce feed for the Mixed Oxide (MOX) Fuel Fabrication Facility, this study included a demonstration of the anion exchange, precipitation and calcination steps expected for the HB-Line process. Specifically, an anion exchange column experiment produced $1.76 \mathrm{~L}$ of purified $44.8 \mathrm{~g} / \mathrm{L}$ plutonium $(\mathrm{Pu})$ solution at $1.23 \mathrm{M}$ free acid. After increasing the acidity to $1.54 \mathrm{M}$, researchers performed two batches of $\mathrm{Pu}(\mathrm{IV})$ oxalate precipitation at $50{ }^{\circ} \mathrm{C}$ using precipitation times expected in HB-Line. The resulting two batches of $\mathrm{Pu}$ oxalate were calcined separately at $650{ }^{\circ} \mathrm{C}$ for nominally four hours to yield plutonium dioxide $\left(\mathrm{PuO}_{2}\right)$. During calcination, a flow of air passed through the furnace.

Replicate samples of $\mathrm{PuO}_{2}$ from the Demo 1 batch, which had limited exposure to humid air, showed TGA mass losses of $0.33-0.34$ wt \% when heated to $1000{ }^{\circ} \mathrm{C}$. Mass spectrometry evaluation of these samples indicated moisture contents of $0.30-0.32 \mathrm{wt} \%$. Exposing Demo 1 material to humid air (44-60\% relative humidity [RH]) for four days yielded material that likely contained $\sim 0.6 \mathrm{wt} \%$ moisture.

Subsequent studies with Demo 1 sample portions exposed to humid air showed that placing the $\mathrm{PuO}_{2}$ in a stream of dry argon gas for 1 hour caused release of significant amounts of moisture. Testing achieved a moisture loss of $0.26 \mathrm{wt} \%$ at room temperature and $0.44 \mathrm{wt} \%$ at $\sim 93{ }^{\circ} \mathrm{C}$. Assuming an estimated starting moisture content of $\sim 0.6 \mathrm{wt} \%$, this preliminary study suggests that the use of a dry argon purge may be sufficient to achieve the required moisture content of $<0.50 \mathrm{wt} \%$. Unfortunately, a TGA instrument problem occurred that prevented the confirmation that the remaining moisture content in the samples purged with argon was $<0.50 \mathrm{wt} \%$. Though the argon purge results are attractive for sample sizes of $\sim 1 \mathrm{~g}$, further studies are needed to assess the feasibility of purging batches of $1 \mathrm{~kg}$ or more with dry gas and the conditions needed to consistently attain $<0.50 \mathrm{wt} \%$ moisture.

During normal TGA-MS operations, the Demo 1 sample characteristics were consistent with an earlier study of small-scale samples produced via similar conditions. In both cases, the bulk of the moisture released from samples by $300{ }^{\circ} \mathrm{C}$, as did a significant portion of the carbon dioxide $\left(\mathrm{CO}_{2}\right)$. As with earlier samples, the Demo 1 material released a minor amount of nitric oxide (NO) in the $\sim 40-300{ }^{\circ} \mathrm{C}$ range, but did not release carbon monoxide (CO) or sulfur dioxide $\left(\mathrm{SO}_{2}\right)$.

Both batches of $\mathrm{PuO}_{2}$ produced in this study exhibited good purity. In the oxide product there were five elements that may exceed the limit for MOX oxide feed - gadolinium (Gd), potassium $(\mathrm{K})$, molybdenum (Mo), phosphorus (P), and silicon ( $\mathrm{Si})$. Of these, four of the analyte (K, Mo, $\mathrm{P}$, and $\mathrm{Si}$ ) measurements were below the method detection limit. Therefore, only Gd was positively detected above the limit. Of the five elements that exceeded the limit in the oxide product, four of them (K, Mo, P, and $\mathrm{Si}$ ) are also above the limit in the Pu feed solution to precipitation. However, in all four cases, the concentrations in the $\mathrm{Pu}$ feed solution were also below the measurement detection limit. Of the four elements (K, Mo, P, and $\mathrm{Si}$ ) that exceed the oxide product limit while being below the method detection limits, none of them are expected to be retained by the anion exchange column, nor are they expected to precipitate with oxalic acid. Consequently, based on process knowledge and the absence of data positively confirming that $\mathrm{K}$, $\mathrm{Mo}, \mathrm{P}$, and Si were above the limit, it is likely that they were below the limit. Additional method development is needed to provide verification that the purity levels can be achieved for those elements. 
The analyses show that Gd was at $\sim 30 \%$ of the limit in the feed solution prior to precipitation, compared to 150 and $60 \%$ for the first and second batches of $\mathrm{PuO}_{2}$, respectively, after calcination. The additional impurity may have resulted from using filtration equipment that was not thoroughly cleaned and recycling the filtrate to rinse precipitate out of the beaker. This potential cause is consistent with the first batch containing more Gd than the second batch, as the equipment would have been rinsed somewhat during first batch operations. Because the purity specification for Gd is quite low at $3 \mu \mathrm{g} / \mathrm{g}$ Pu (Column A) and Gd has been used in H Canyon dissolution campaigns, it will be important to ensure that the MOX Feed process equipment be adequately cleaned to ensure $\mathrm{PuO}_{2}$ product batches meet specifications. In addition, a check of the purity of feed chemicals and process solutions should be considered by HB-Line to ensure sufficient product purity.

The carbon content of the two calcination batches of $\mathrm{PuO}_{2}$ was $280-290 \mu \mathrm{g} \mathrm{C/g} \mathrm{Pu}$, which meets the $1000 \mu \mathrm{g} \mathrm{C} / \mathrm{g} \mathrm{Pu}$ specification. The $\mathrm{PuO}_{2}$ samples produced in both batches had particles sizes that ranged from $0.2-74.0 \mu \mathrm{m}$, with mean particle sizes of $11.8-12.2 \mu \mathrm{m}$. These results meet the specification of $<200 \mu \mathrm{m}$. For the two batches, the volume percent of particles $<5.50 \mu \mathrm{m}$ was $13.9-14.0 \%$. The specific surface areas of the $\mathrm{PuO}_{2}$ samples were $9.22-9.63 \mathrm{~m}^{2} / \mathrm{g}$. 


\section{TABLE OF CONTENTS}

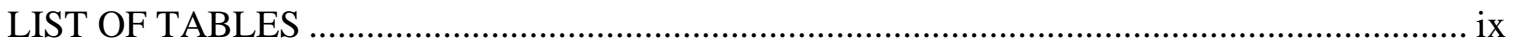

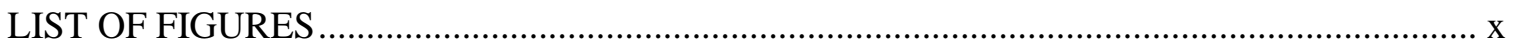

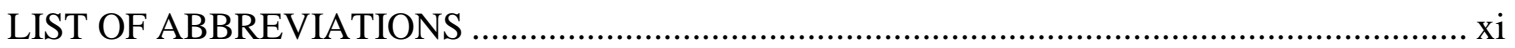

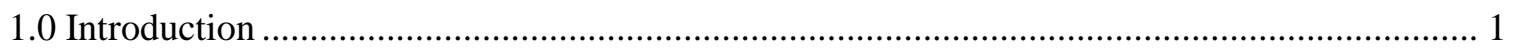

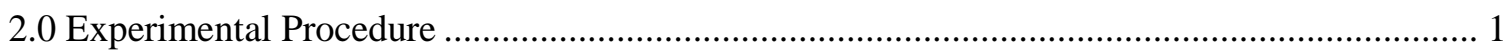

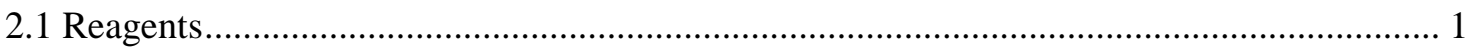

2.2 Plutonium Purification by Anion Exchange ................................................................. 1

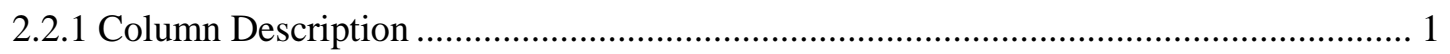

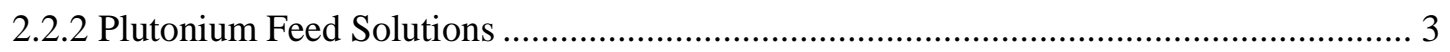

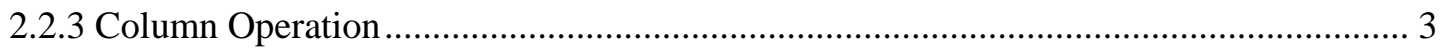

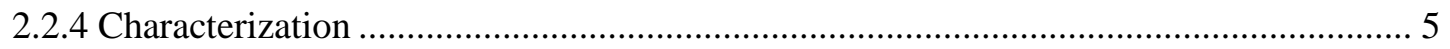

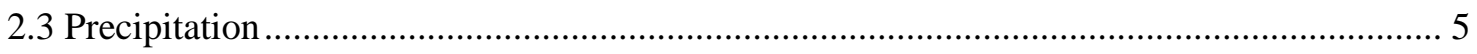

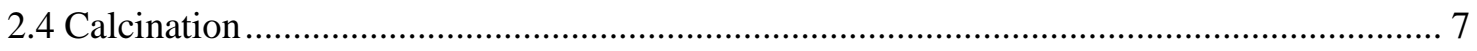

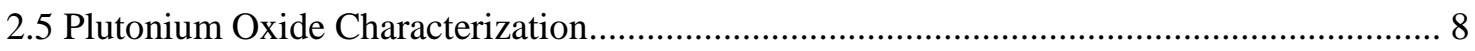

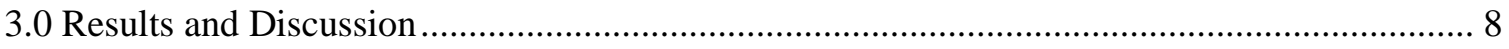

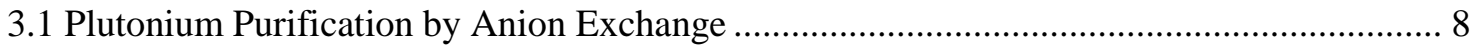

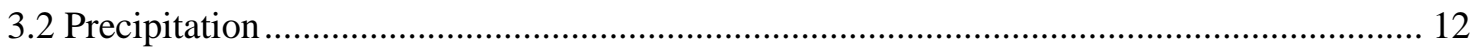

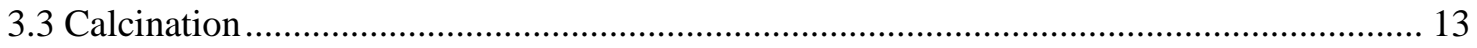

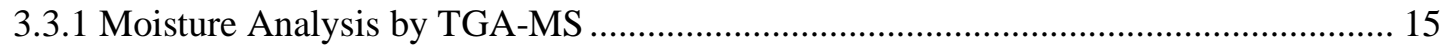

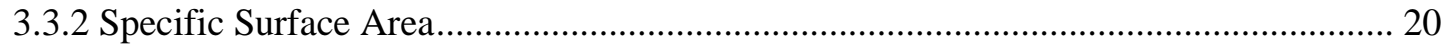

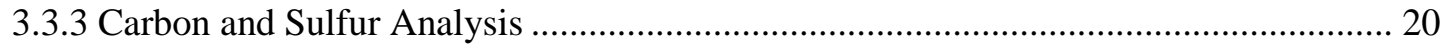

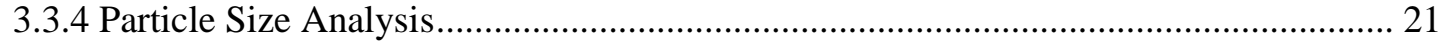

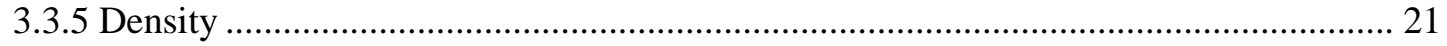

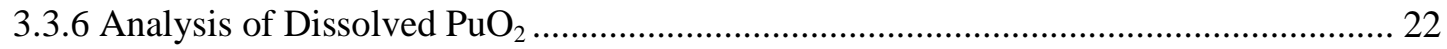

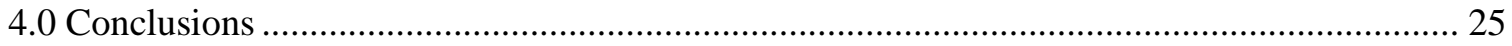

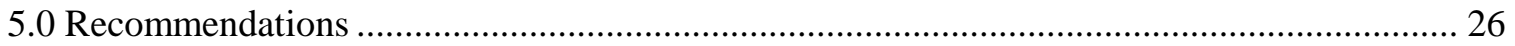

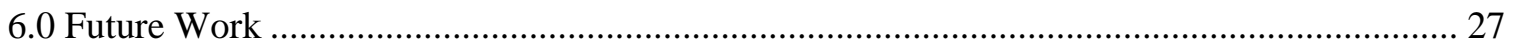

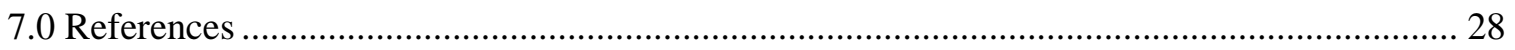




\section{LIST OF TABLES}

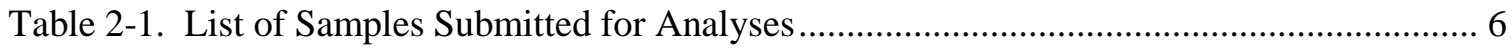

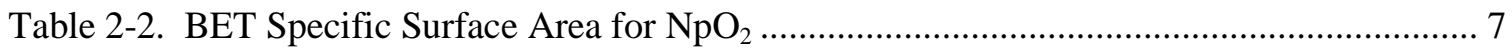

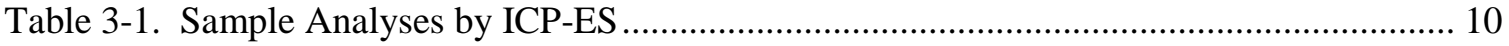

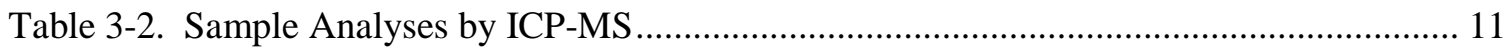

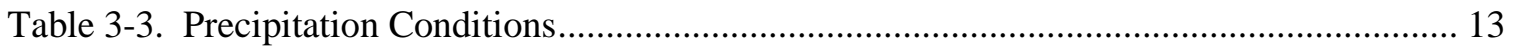

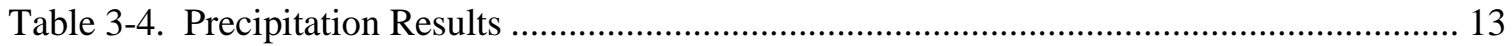

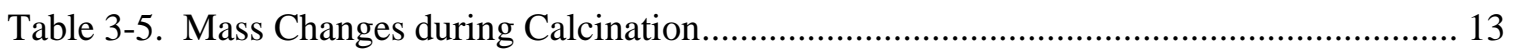

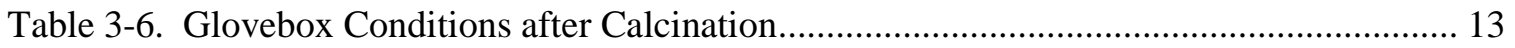

Table 3-7. TGA-MS Results for Integrated Demonstration "Demo 1” Sample............................ 17

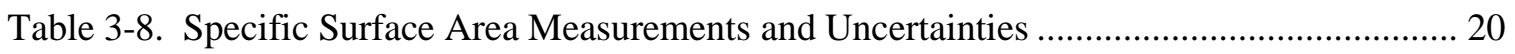

Table 3-9. Carbon and Sulfur Contents of $\mathrm{PuO}_{2}$ Samples......................................................... 21

Table 3-10. Particle Size Analyses of Pu Oxalate and $\mathrm{PuO}_{2}$ Samples ......................................... 21

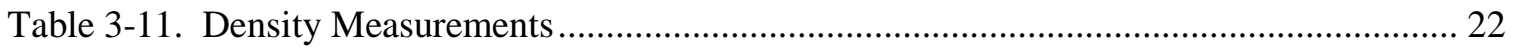

Table 3-12. Impurity Contents of Dissolved $\mathrm{PuO}_{2}$ Solution ..................................................... 23

Table 3-13. Impurity Contents of Starting Hearts-Cut Pu Solution ........................................... 24

Table A-1. Sample Analyses by Gamma Spectroscopy and Pu TTA. .................................... A-2

Table A-2. Additional Anion Exchange Operating Data. …....................................................... A-3

Table A-3. Comparison of Primary Feed and Raffinate Contents by ICP-ES. ......................... A-4

Table A-4. Comparison of Primary Feed and Raffinate Contents by ICP-MS. ........................ A-5

Table A-5. Uncertainties in MS Moisture Contents................................................................ A-7

Table A-6. Analyses of Reagents by ICP-ES and Total Acid.............................................. A-13

Table A-7. Analyses of Reagents by ICP-MS................................................................... A-14 


\section{LIST OF FIGURES}

Figure 2-1. Ion Exchange Column in Glovebox.................................................................. 2

Figure 2-2. Ion Exchange Column Screen for Resin Retention ................................................... 2

Figure 2-3. Ion Exchange Resin 1) after Loading, 2) during Washing, and 3) during Elution ...... 5

Figure 3-1. Pu and ${ }^{241} \mathrm{Am}$ Released from Resin Column ........................................................ 9

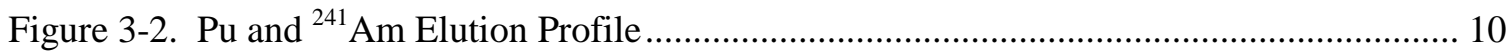

Figure 3-3. Left: Demo 1 Pu Oxalate; Right: Demo $2 \mathrm{PuO}_{2}$ after Calcination. ........................... 14

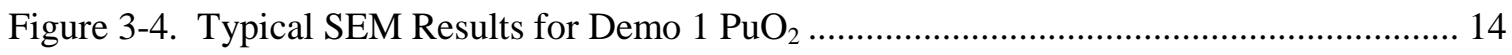

Figure 3-5. SEM Results for Demo $2 \mathrm{PuO}_{2}$, Showing Some Irregular Particles.......................... 15

Figure 3-6. SEM Results for Demo $2 \mathrm{PuO}_{2}$, Showing Typical Particles .................................... 15

Figure 3-7. TGA Mass Measurements for Demo 1a and Demo 1b Samples ............................... 16

Figure 3-8. MS Signals (linear scale) from TGA-MS Analysis of Demo 1a Sample .................. 16

Figure 3-9. MS Signals (logarithmic scale) from TGA-MS Analysis of Demo 1a Sample ......... 17

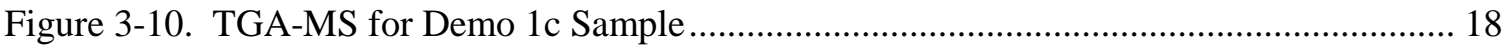

Figure 3-11. TGA-MS for Demo 1 Sample in Dry Argon at Room Temperature for 1 h............ 19

Figure 3-12. TGA-MS for Demo 1 Sample in Dry Argon at $~ 50{ }^{\circ} \mathrm{C}$ for $1 \mathrm{~h}$............................... 19

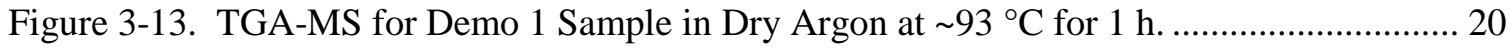

Figure A-1. Temperature Profiles for Demo 1 Calcination..................................................... A-8

Figure A-2. Temperature Profiles for Demo 2 Calcination.................................................... A-8

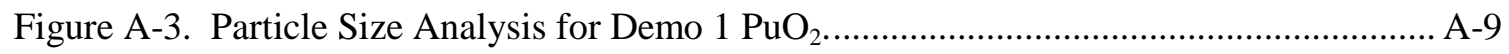

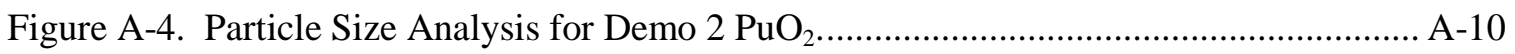

Figure A-5. Particle Size Analysis for Demo 1 Pu Oxalate.. ….............................................. A-11

Figure A-6. Particle Size Analysis for Demo 2 Pu Oxalate ................................................ A-12 


\section{LIST OF ABBREVIATIONS}

$\begin{array}{ll}\text { ANN } & \text { aluminum nitrate nonahydrate } \\ \text { BET } & \text { Brunauer-Emmett-Teller } \\ \text { BV } & \text { bed volume } \\ \text { DE } & \text { Destructive Evaluation } \\ \text { DI } & \text { deionized water } \\ \text { FMI } & \text { Fluid Metering Inc. } \\ \text { IC } & \text { ion chromatography } \\ \text { ICP-ES } & \text { inductively coupled plasma emission spectroscopy } \\ \text { ICP-MS } & \text { inductively coupled plasma mass spectroscopy } \\ \text { MOX } & \text { Mixed Oxide } \\ \text { PHA } & \text { pulse height analysis } \\ \text { PSA } & \text { particle size analysis } \\ \text { RH } & \text { relative humidity } \\ \text { SEM } & \text { scanning electron microscopy } \\ \text { SRNL } & \text { Savannah River National Laboratory } \\ \text { SSA } & \text { specific surface area } \\ \text { TGA-MS } & \text { thermogravimetric analysis-mass spectrometry }\end{array}$




\subsection{Introduction}

$\mathrm{H}$-Canyon and HB-Line are tasked with the production of $\mathrm{PuO}_{2}$ from a feed of plutonium metal. The $\mathrm{PuO}_{2}$ will provide feed material for the MOX Fuel Fabrication Facility. After dissolution of the Pu metal in H-Canyon, the solution will be transferred to HB-Line for purification by anion exchange. Subsequent unit operations include $\mathrm{Pu}(\mathrm{IV})$ oxalate precipitation, filtration and calcination to form $\mathrm{PuO}_{2}$. This report details the results from SRNL anion exchange, precipitation, filtration, calcination, and characterization tests, as requested by HB-Line ${ }^{1}$ and described in the task plan ${ }^{2}$. This study involved an $80-\mathrm{g}$ batch of Pu and employed test conditions prototypical of HB-Line conditions, wherever feasible. In addition, this study integrated lessons learned from earlier anion exchange ${ }^{3}$ and precipitation and calcination ${ }^{4}$ studies.

H-Area Engineering selected direct strike Pu(IV) oxalate precipitation ${ }^{5}$ to produce a more dense $\mathrm{PuO}_{2}$ product than expected from $\mathrm{Pu}(\mathrm{III})$ oxalate precipitation. One benefit of the $\mathrm{Pu}(\mathrm{IV})$ approach is that it eliminates the need for reduction by ascorbic acid. The proposed HB-Line precipitation process $^{1,2}$ involves a digestion time of 5 minutes after the time (44 min) required for oxalic acid addition. These were the conditions during HB-line production of neptunium oxide $\left(\mathrm{NpO}_{2}\right)$. In addition, a series of small $\mathrm{Pu}(\mathrm{IV})$ oxalate precipitation tests with different digestion times were conducted to better understand the effect of digestion time on particle size, filtration efficiency and other factors. ${ }^{4}$

To test the recommended process conditions, researchers performed two nearly-identical largerscale precipitation and calcination tests. The calcined batches of $\mathrm{PuO}_{2}$ were characterized for density, specific surface area (SSA), particle size, moisture content, and impurities.

Because the 3013 Standard requires that the calcination (or stabilization) process eliminate organics, characterization of $\mathrm{PuO}_{2}$ batches monitored the presence of oxalate by thermogravimetric analysis-mass spectrometry (TGA-MS). To use the TGA-MS for carbon or oxalate content, some method development will be required. However, the TGA-MS is already used for moisture measurements. Therefore, SRNL initiated method development for the TGA-MS to allow quantification of oxalate or total carbon. That work continues at this time and is not yet ready for use in this study. However, the collected test data can be reviewed later as those analysis tools are available.

\subsection{Experimental Procedure}

\subsection{Reagents}

Reagent-grade nitric and oxalic acids were used for anion exchange and precipitation solutions. Distilled water (from the SRNL laboratory system) was used to dilute feed solutions. Deionized water (i.e., distilled water treated by Millipore Synergy 185 de-ionizer) was used for preparation of all anion exchange wash and elution acid solutions and for the oxalic acid solution used for precipitation. For dissolution of the purified $\mathrm{PuO}_{2}$, the high-purity "Optima" grade $\mathrm{HNO}_{3}$ and $\mathrm{HF}$ were used.

\subsection{Plutonium Purification by Anion Exchange}

\subsubsection{Column Description}

The ion exchange column was fabricated from 54.4-mm (inside diameter) borosilicate glass tubing (1.5-mm wall thickness) by the SRNL Glass Shop (Figure 2-1). A coarse frit was sealed into the bottom of the column to hold the resin. Graduations in "cm" were affixed to the column 
(Figure 2-1). Approximately $1.47 \mathrm{~L}$ of Reillex ${ }^{\mathrm{TM}} \mathrm{HPQ}$ anion exchange resin were loaded into the column for a bed height of $63.5 \mathrm{~cm}$. The top of the column contained a screen that pressed and held the resin in place (Figure 2-2). This enables the column to be used with either upward or downward flow. Solutions were fed to the column using a Fluid Metering Inc. (FMI) QV-50 piston pump. Polyethylene tubing (6.35 mm outside diameter) linked feed bottles, effluent collection bottles, and the pump to the column.
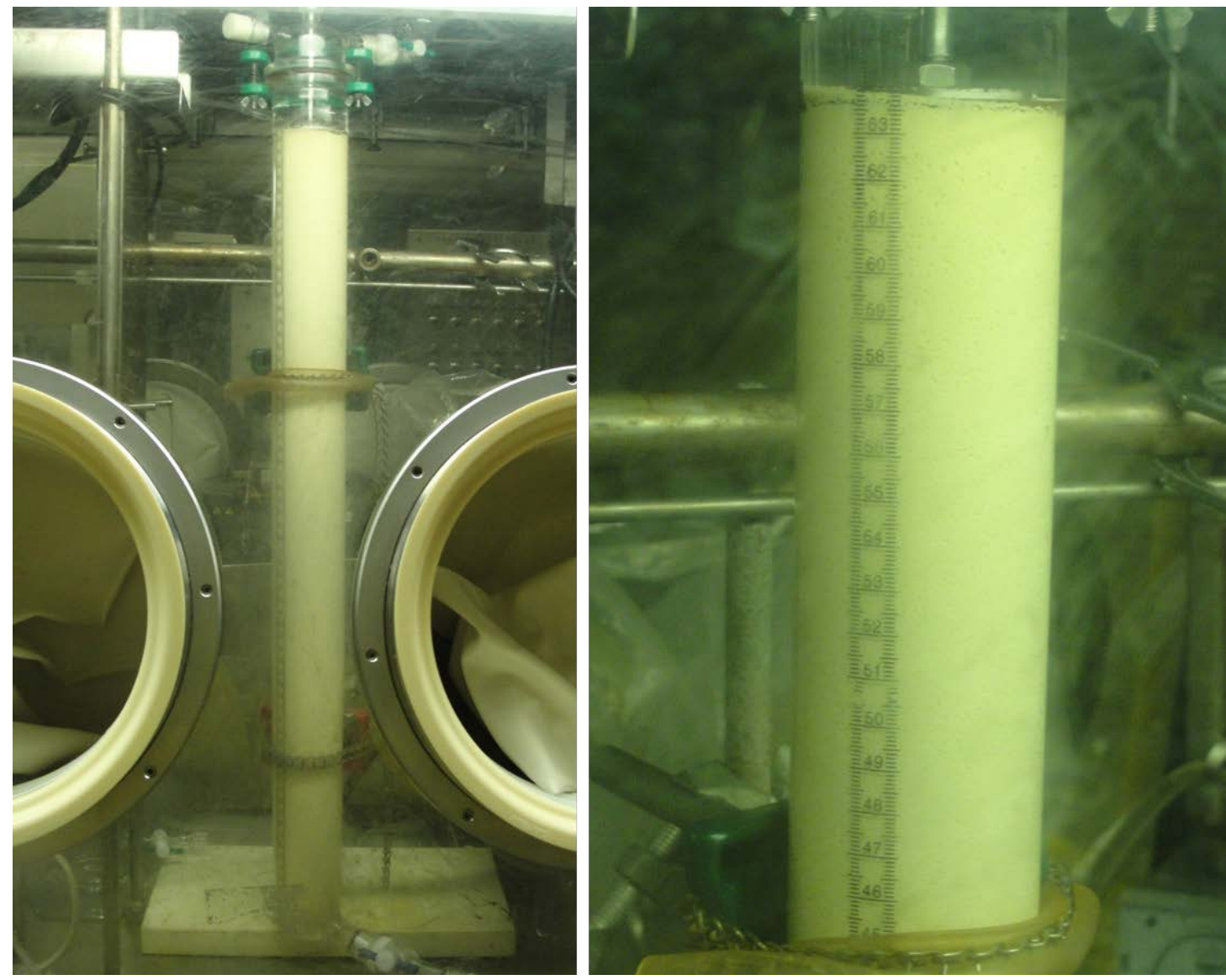

Figure 2-1. Ion Exchange Column in Glovebox

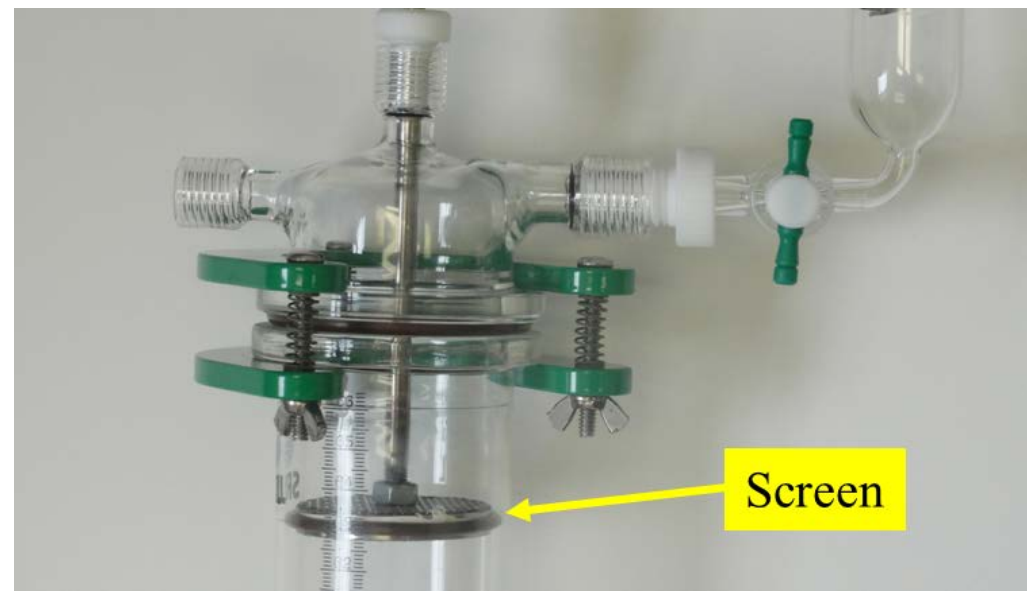

Figure 2-2. Ion Exchange Column Screen for Resin Retention 


\subsubsection{Plutonium Feed Solutions}

Feed solutions came from four source materials. Only Feed 4 was formulated to match the expected characteristics of $\mathrm{Pu}$ solution from $\mathrm{H}$-Canyon. Consequently, the four feed sources were not blended. Feeds 1-3 were provided to increase the amount of Pu loading on the column.

1) 1.0 L of legacy Pu solution from sodium peroxide fusion of 3013 Destructive Evaluation (DE) material. The total $\mathrm{NO}_{3}{ }^{-}$concentration was $\sim 7.5 \mathrm{M}$ and the $\mathrm{HNO}_{3}$ concentration was $\sim 6 \mathrm{M}$. The solution contained $\sim 8.2 \mathrm{~g}$ of Pu. Due to the uncertainty associated with the solution, the solution was treated with ferrous sulfamate to convert $\mathrm{Pu}^{6+}$ to $\mathrm{Pu}^{3+}$, heated to $50{ }^{\circ} \mathrm{C}$ for $60 \mathrm{~min}$ to convert $\mathrm{Pu}^{3+}$ to $\mathrm{Pu}^{4+}$, and acidified with $15.7 \mathrm{M} \mathrm{HNO}_{3}$ to a final volume of $1550 \mathrm{~mL}$.

2) $250 \mathrm{~mL}$ of dissolved $\delta$-phase metal. The solution contained $\sim 0.4 \mathrm{~g}$ of Pu. The solution concentrations were $10 \mathrm{M} \mathrm{HNO}_{3}, \sim 0.05 \mathrm{M} \mathrm{KF}$, and $1.5 \mathrm{~g} / \mathrm{L} \mathrm{Gd}$. To the solution were added $12.5 \mathrm{~mL}$ of $2.0 \mathrm{M}$ aluminum nitrate nonahydrate (ANN) solution to complex fluoride at a 2:1 Al:F molar ratio and $50 \mathrm{~mL}$ distilled water to reduce the total $\mathrm{NO}_{3}{ }^{-}$ concentration, yielding an $\mathrm{HNO}_{3}$ concentration of $8 \mathrm{M}$ and a nitrate concentration of 8.2 M. The solution was not filtered after the addition of ANN and distilled $\mathrm{H}_{2} \mathrm{O}$.

3) $850 \mathrm{~mL}$ of dissolved $\delta$-phase metal. The solution contained $\sim 4.3 \mathrm{~g}$ of Pu. The solution concentrations were $9.3 \mathrm{M} \mathrm{HNO}_{3}, \sim 0.044 \mathrm{M} \mathrm{KF}$, and $0.67 \mathrm{~g} / \mathrm{L} \mathrm{Gd}$. To the solution were added $40 \mathrm{~mL}$ of $2.0 \mathrm{M}$ ANN solution to complex fluoride at a 2:1 Al:F molar ratio and 60 $\mathrm{mL}$ distilled water to reduce the total $\mathrm{NO}_{3}^{-}$concentration, yielding an $\mathrm{HNO}_{3}$ concentration of $8.3 \mathrm{M}$ and a nitrate concentration of $8.6 \mathrm{M}$. The solution was not filtered after the addition of ANN and distilled $\mathrm{H}_{2} \mathrm{O}$.

4) $14.9 \mathrm{~L}$ of dissolved $3013 \mathrm{DE}$ materials from several sources. The material was dissolved using sodium peroxide fusion. Consequently, the solution was high in sodium (Na). The solution contained $\sim 75 \mathrm{~g}$ of Pu. The total $\mathrm{NO}_{3}{ }^{-}$concentration was $\sim 8.3 \mathrm{M}$ and the $\mathrm{HNO}_{3}$ concentration was $\sim 7.9 \mathrm{M}$. The solution was filtered through a 5-micron filter. In addition, the following chemicals were added to the solution on a per-liter basis.

- Gallium (Ga): 2 wt \% of the Pu feed ( $\sim 5 \mathrm{~g} / \mathrm{L}$ ) was added as gallium nitrate [0.374 g].

- Boron (B): $1.2 \mathrm{~g} / \mathrm{L}$ was added as boric acid [6.86 g].

- Potassium fluoride (KF): $0.08 \mathrm{M}$ was added as KF [4.65 g].

- Aluminum (Al): 2 mol of $\mathrm{Al}$ per mol of fluoride added as aluminum nitrate nonahydrate (ANN) [60.0 g].

- Chloride: $5 \mathrm{mg}$ chloride per gram of Pu added as sodium chloride ( $\mathrm{NaCl})$ [0.041 g].

- Iron and packaging can: $0.23 \mathrm{~g}$ per gram of Pu added as packaging can [1.16 g].

- Nylon bag: $0.0093 \mathrm{~g}$ per gram of Pu added as nylon sleeve [0.046 g].

\subsubsection{Column Operation}

The ion exchange resin was conditioned with downward flow, loaded and washed with upward flow, and eluted with downward flow. Although HB-Line conditions in the upward flow direction, the difference in operation for conditioning will not affect the test results.

Prior to loading $\mathrm{Pu}$ onto the resin, the column was conditioned with $3 \mathrm{~L}$ of $8 \mathrm{M} \mathrm{HNO}_{3}$ at $\sim 90 \mathrm{~mL} / \mathrm{min}$. Plutonium feed solutions were fed to the column at an average rate of $87 \mathrm{~mL} / \mathrm{min}$ (maximum of $118 \mathrm{~mL} / \mathrm{min}$ and minimum of $71 \mathrm{~mL} / \mathrm{min}$ ). Feed solutions $1-3$ listed above were combined and fed to the column first. Afterward, the $14.9 \mathrm{~L}$ of primary feed (Feed 4 listed above) was fed to the column. After the loading of each bottle, the height of $\mathrm{Pu}$ in the column was recorded. Samples of the composite effluent solutions were submitted for analyses. The effluent from Feeds 1-3 was analyzed as Load Eff 1 . The first $4000 \mathrm{~mL}$ of Item 4 effluent were 
analyzed as Load Eff 2. The next $6000 \mathrm{~mL}$ of Feed 4 effluent were analyzed as Load Eff 3. The final $4900 \mathrm{~mL}$ of Item 4 effluent were analyzed as Load Eff 4.

The column was then washed with $15 \mathrm{~L}$ of $8 \mathrm{M} \mathrm{HNO}_{3}$ to remove non-Pu impurities. The first liter of wash was loaded at $77 \mathrm{~mL} / \mathrm{min}$. Subsequent wash solutions were fed to the column at an average rate of $175 \mathrm{~mL} / \mathrm{min}$ (maximum of $182 \mathrm{~mL} / \mathrm{min}$ and minimum of $167 \mathrm{~mL} / \mathrm{min}$ ). After the loading of each bottle, the height of Pu in the column was recorded. Each composite bottle of wash solution was sampled and analyzed.

After washing was complete, the pump speed was reduced to $56 \mathrm{~mL} / \mathrm{min}$ and the $\mathrm{Pu}$ on the column was eluted with $0.35 \mathrm{M} \mathrm{HNO}_{3}$. The effluent was collected in a graduated bottle. When the volume in the collection bottle was $450 \mathrm{~mL}, 600 \mathrm{~mL}, 750 \mathrm{~mL}$, and $900 \mathrm{~mL}$, grab samples of the effluent solution were collected directly from the column (referred to as Heads 0.3, 0.4, 0.5 and 0.6, respectively). At $1000 \mathrm{~mL}$, Pu was observed eluting from the column and the effluent was directed to a separate graduated collection bottle to collect the Hearts cut. This first $1000 \mathrm{~mL}$ of composite effluent was labeled and analyzed as Heads. Grab samples were collected of the Hearts Product effluent when the total volume reached $1050 \mathrm{~mL}$ and $1200 \mathrm{~mL}$ (referred to as Heads 0.7 and 0.8, respectively, although these samples were collected from the Hearts cut).

When the volume of effluent in the Hearts cut reached $1460 \mathrm{~mL}, 1600 \mathrm{~mL}$, and $1760 \mathrm{~mL}$, samples of the effluent were collected (referred to as Hearts 60,55 , and 50 , respectively). At $1760 \mathrm{~mL}$ in the Hearts cut, the effluent was directed to a separate graduated bottle labeled as Tails 1. Samples of the effluent were collected when the total effluent volume (from the beginning of the Hearts cut) reached $1950 \mathrm{~mL}, 2200 \mathrm{~mL}$, and $2500 \mathrm{~mL}$ (referred to as Hearts 45, 40 , and 35, respectively, although these samples were actually collected from the Tails cut). A sample of the Tails 1 composite bottle was also collected for analysis.

At this time, the effluent was directed to a bottle labeled as Tails 2, and the pump rate was increased to $\sim 120 \mathrm{~mL} / \mathrm{min}$. Approximately $1900 \mathrm{~mL}$ of $0.35 \mathrm{M} \mathrm{HNO}_{3}$ was fed through the column and collected in the Tails 2 bottle. A sample of the Tails 2 composite bottle was collected for analysis. Pictures of the column 1) after loading, 2) during washing, and 3) during elution are shown in Figure 2-3. 

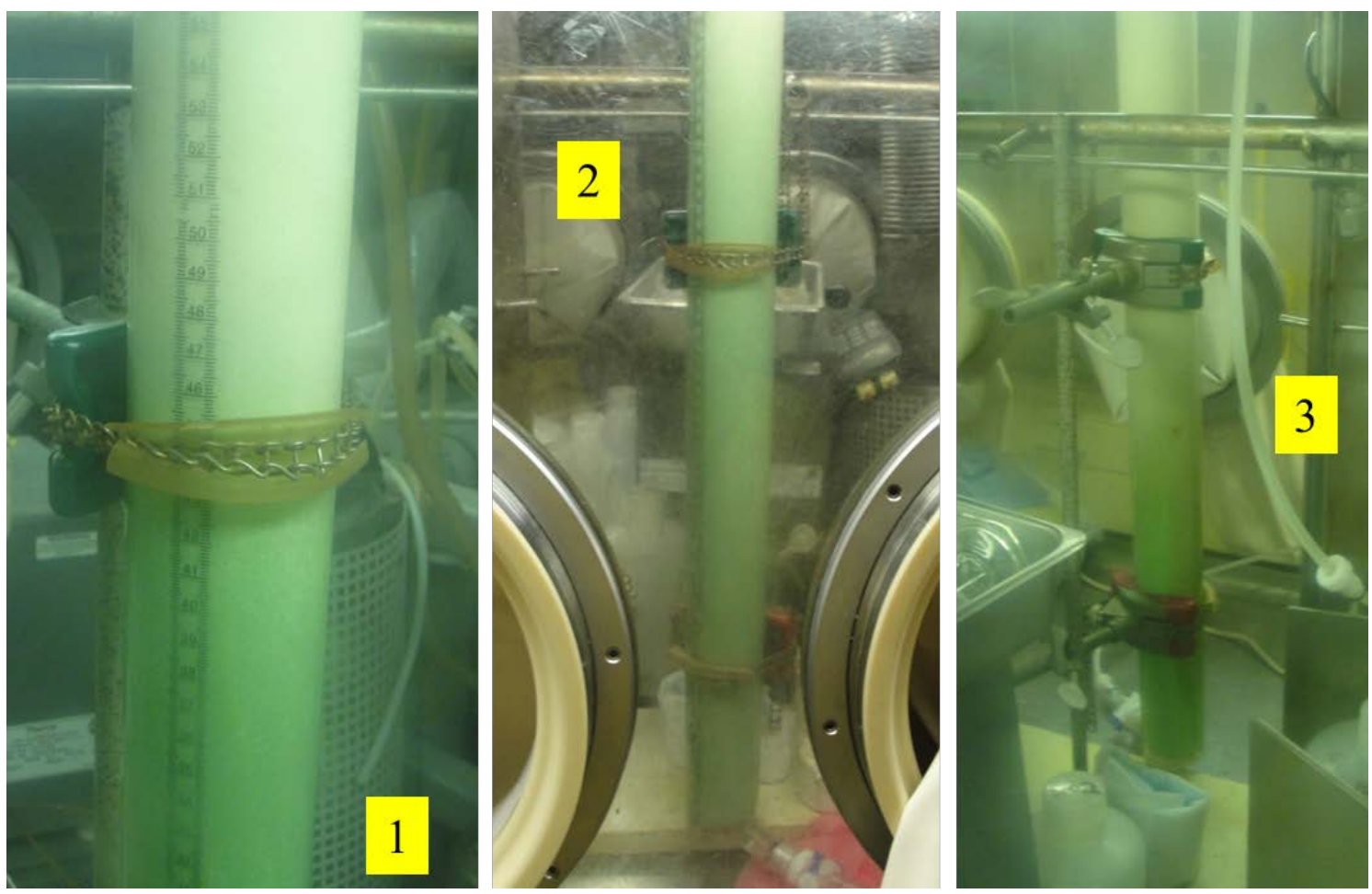

Figure 2-3. Ion Exchange Resin 1) after Loading, 2) during Washing, and 3) during Elution

\subsubsection{Characterization}

A list of samples collected and analyses conducted is provided in Table 2-1. The samples with volume of $2 \mathrm{~mL}$ are grab samples. Note that after analysis of the Product solution, the acidity of the Product was increased by addition of $7.0 \mathrm{M} \mathrm{HNO}_{3}$. The resulting Adjusted Product solution was analyzed and used for precipitation. Samples for inductively coupled plasma-emission spectroscopy (ICP-ES) were submitted in plastic sample vials; all other samples were submitted in glass sample vials.

The feed, product and other effluent solutions from the anion exchange column experiment were characterized by some or all of these methods: gamma pulse height analysis (PHA), inductively coupled plasma-mass spectroscopy (ICP-MS), ICP-ES, ion chromatograpy (IC) for anions, and free acid. To achieve lower detection limits and reduce interferences for some impurities in the $\mathrm{Pu}$ product solution, the Pu product solution was analyzed by ICP-MS and ICP-ES after Pu removal. The details of that method development effort are reported elsewhere. ${ }^{6}$

\subsection{Precipitation}

The Pu product solution described above was sampled and then re-sampled a week later after thorough mixing. After receiving the acid analysis of the well-mixed solution, a researcher added 7.0 $\mathrm{M} \mathrm{HNO}_{3}$ to raise the Pu solution to a target concentration of $\sim 1.5 \mathrm{M} \mathrm{HNO}_{3}$. The researcher then mixed the Adjusted Product solution, sampled it, and initiated the first precipitation with approximately half of the Pu solution. The next day, the researcher performed the second precipitation with the remaining solution. No valence adjustments were performed before either of the precipitation steps. Prior to each precipitation batch, researchers calculated the volume of $0.9 \mathrm{M}$ oxalic acid needed to achieve $0.1 \mathrm{M}$ excess oxalic acid after Pu precipitation. That volume of $0.9 \mathrm{M}$ oxalic acid was transferred into a $250-\mathrm{mL}$ bottle. For each precipitation, purified $\mathrm{Pu}$ solution was heated in a stainless steel beaker to $50 \pm 2{ }^{\circ} \mathrm{C}$. Researchers used a 2-L stainless steel 
beaker for both batches (nominally $40 \mathrm{~g}$ Pu each). Once the Pu solution reached nominally $50{ }^{\circ} \mathrm{C}$, $0.9 \mathrm{M}$ oxalic acid was added at a flow rate of $12.5 \mathrm{~mL} / \mathrm{min}$ to target a total oxalic acid addition time of 44 minutes, which corresponds to expected HB-Line precipitation conditions. ${ }^{5} \mathrm{~A}$ summary of the precipitation conditions is provided in the Results section.

Table 2-1. List of Samples Submitted for Analyses

\begin{tabular}{|c|c|c|c|}
\hline Sample ID & "Volume (mL) & AD \# & Analyses* \\
\hline Feed Item 1 & 1550 & 300299075 & $1,3,4$ \\
\hline Feed Item 4 & 14900 & 300299076 & $1,3,4$ \\
\hline Load Eff 1 & 2250 & 300299083 & 1,2 \\
\hline Load Eff 2 & 4000 & 300299084 & 1,2 \\
\hline Load Eff 3 & 6000 & 300299085 & 1,2 \\
\hline $\begin{array}{l}\text { Raffinate of } \\
\text { Primary Feed }\end{array}$ & 2 & 300299322 & $3,4,5$ \\
\hline Load Eff 4 & 4600 & 300299086 & 1,2 \\
\hline Wash 1 & 1000 & 300299089 & $1,3,4$ \\
\hline Wash 2 & 2000 & 300299090 & $1,3,4$ \\
\hline Wash 3 & 2000 & 300299091 & $1,3,4$ \\
\hline Wash 4 & 2000 & 300299092 & $1,3,4$ \\
\hline Wash 5 & 2000 & 300299093 & $1,3,4$ \\
\hline Wash 6 & 2000 & 300299094 & $1,3,4$ \\
\hline Wash 7 & 2000 & 300299095 & $1,3,4$ \\
\hline Wash 8 & 2000 & 300299096 & $1,3,4$ \\
\hline Heads 0.3 & 2 & 300299097 & 1 \\
\hline Heads 0.4 & 2 & 300299098 & 1 \\
\hline Heads 0.5 & 2 & 300299099 & 1 \\
\hline Heads 0.6 & 2 & 300299100 & 1 \\
\hline Heads 0.7 & 2 & 300299101 & 1 \\
\hline Heads 0.8 & 2 & 300299102 & 1 \\
\hline Heads & 1000 & 300299103 & 1 \\
\hline Product & 1760 & 300299294 & $1,3,4,5,6,7$ \\
\hline Adjusted Product & 1890 & 300299638 & 1,6 \\
\hline Hearts 60 & 2 & 300299077 & 1 \\
\hline Hearts 55 & 2 & 300299078 & 1 \\
\hline Hearts 50 & 2 & 300299079 & 1 \\
\hline Hearts 45 & 2 & 300299080 & 1 \\
\hline Hearts 40 & 2 & 300299081 & 1 \\
\hline Hearts 35 & 2 & 300299082 & 1 \\
\hline Tails 1 & 1000 & 300299087 & 1 \\
\hline Tails 2 & 1900 & 300299088 & 1 \\
\hline \multicolumn{4}{|c|}{$\begin{array}{l}* \text { Analytical methods below with typical uncertainties. } \\
1=\text { gamma spectroscopy, } \pm 5 \% \\
2=\text { Pu TTA }, \pm 5 \% \\
3=\text { inductively coupled plasma mass spectroscopy (ICP-MS), } \pm 20 \% \\
4=\text { inductively coupled plasma emission spectroscopy (ICP-ES), } \pm 10 \% \\
5=\text { ion chromatography (IC), } \pm 10 \% \\
6=\text { total acid } / \text { free acid, } \pm 10 \% \\
7=\text { Additional ICP-MS and ICP-ES analysis after Pu removal }\end{array}$} \\
\hline
\end{tabular}


For both 40-g precipitation batches, the digestion time, or time between the end of oxalic acid addition and the start of filtration, was 5 minutes. Following each precipitation, the Pu oxalate slurry was poured into a stainless steel filter housing containing a nominally $10-\mu \mathrm{m}$ stainless steel filter screen material provided by HB-Line. The bulk of the Pu oxalate slurry was transferred to the filter housing and the liquid was vacuum filtered and collected in a 1-L filter flask. Then, the filter apparatus was moved to a second 1-L filter flask. Filtration continued and the filtrate recovered in the first flask was used to rinse the slurry out of the stainless steel beaker until essentially all Pu oxalate solids were in the filter housing.

During filtration, cake washing (with $1.4 \mathrm{M} \mathrm{HNO}_{3} / 0.1 \mathrm{M}$ oxalic acid) did not occur nor was cake wash solution added to the precipitator vessel, as is done in HB-Line to assist in flushing the solids out of the precipitator. Thus, this study was conservative in the sense that the use of some cake wash solution, as done in HB-Line, would likely improve the purity of the final $\mathrm{PuO}_{2}$ product because the cake wash or flush solution dilutes the impurities held up in the filter cake.

For Demo 1, the vacuum continued to operate for 10 minutes after standing liquid was gone from the cake. The cake was left open overnight and vacuum was again applied for 40-50 minutes the next day. Then Demo 1 cake was transferred to a tared quartz crucible and weighed. The crucible containing the Demo 1 oxalate cake was left on the balance and additional mass measurements were recorded to gauge drying.

The stainless steel beaker used during precipitation was cleaned with $1.4 \mathrm{M} \mathrm{HNO}_{3} / 0.1 \mathrm{M}$ oxalic acid and rinsed three times with distilled water prior to the second (Demo 2) precipitation. After the Demo 2 precipitation and filtration, vacuum filtration continued for approximately 15 minutes after no liquid was visible on top of the cake. The cake was exposed to air overnight. Filtrate solutions were characterized by gamma PHA to determine $\mathrm{Pu}$ losses to the filtrate. Filtrate solutions were also characterized by ICP-MS, ICP-ES and IC. Samples of $\mathrm{Pu}\left(\mathrm{C}_{2} \mathrm{O}_{4}\right)_{2}$ from both Demo 1 and 2 were evaluated for Particle Size Analysis (PSA) in a solution of $1.4 \mathrm{M} \mathrm{HNO}_{3} /$ $0.1 \mathrm{M}$ oxalic acid.

\subsection{Calcination}

Calcinations were performed in a nominal 110-mL quartz crucible. Each crucible had a Puoxalate bed depth of approximately $2-3 \mathrm{~cm}$. As noted in previous SRNL work ${ }^{7}$ with neptunium oxide $\left(\mathrm{NpO}_{2}\right)$ calcinations, we assumed that a bed depth of 2-3 cm (or less for later in this study) would allow enough air to permeate the powder during calcination that the $\mathrm{PuO}_{2}$ produced would be similar to that produced in HB-Line at similar conditions. This assumption seems reasonable because in the case of $\mathrm{NpO}_{2}$, the batches of $\mathrm{NpO}_{2}$ calcined at SRNL at 600 and $650{ }^{\circ} \mathrm{C}$ for 2 hours had specific surface areas which bounded that of the $\mathrm{NpO}_{2}$ made by HB-Line early in the production campaign as shown in Table 2-2. ${ }^{8}$ The HB-Line design, which passes air through the filter cake (or powder bed) during calcination, effectively removes moisture and oxalate decomposition products from the filter cake. The design may have other advantages for the properties of the $\mathrm{PuO}_{2}$.

Table 2-2. BET Specific Surface Area for $\mathrm{NpO}_{2}$

\begin{tabular}{|c|c|}
\hline \hline $\mathbf{N p O}_{2}$ Material & $\begin{array}{c}\text { BET Specific Surface Area, } \\
\mathbf{m}^{2} / \mathbf{g}\end{array}$ \\
\hline SRNL $600^{\circ} \mathrm{C}$ & 5.34 \\
\hline SRNL $650{ }^{\circ} \mathrm{C}$ & 3.67 \\
\hline HB-Line & 4.03 \\
\hline
\end{tabular}


The target calcination conditions for the study were 40-44 g Pu in each batch, calcined at $650{ }^{\circ} \mathrm{C}$ for four hours. For the first batch, the actual calcination time extended to $4.5 \mathrm{~h}$ due to an unexpected laboratory safety condition. Following each calcination, the resulting $\mathrm{PuO}_{2}$ was cooled briefly and transferred to a glass jar, which was placed inside two zippered plastic bags.

\subsection{Plutonium Oxide Characterization}

The $\mathrm{PuO}_{2}$ sample from the Demo 1 batch was characterized by thermogravimetric analysis-mass spectrometry (TGA-MS) for moisture content, which included initial duplicate analysis as well as analyses after exposure to humid air. Measurements were made using a Netzsch 409 PC Luxx ${ }^{\circledR}$ TGA and a Pfeiffer Thermostar ${ }^{\mathrm{TM}}$ MS. An argon purge stream passed through the TGA sample chamber, then through a tube heated to $180{ }^{\circ} \mathrm{C}$, to a sample point where the MS continuously samples the TGA off-gas. The TGA-MS was calibrated for moisture using gypsum $\left(\mathrm{CaSO}_{4} \cdot 2 \mathrm{H}_{2} \mathrm{O}\right)$ standards. This study used a calibrated Vaisala HM34F temperature and humidity meter for measuring glovebox conditions during Demo 1 analyses and exposures; however, Demo 2 analyses were delayed due to TGA instrument issues.

Samples of $\mathrm{PuO}_{2}$ from both Demo 1 and Demo 2 were characterized by (1) the BrunauerEmmett-Teller (BET) method for SSA using a Micromeritics 2365 Gemini surface area analyzer, (2) PSA using a Microtrac X100 Particle Size Analyzer with a 250-mL recirculator and a distilled water matrix, (3) Scanning Electron Microscopy (SEM), (4) bulk and tapped density, pycnometry density, carbon/sulfur analysis, and (5) dissolution in $12 \mathrm{M} \mathrm{HNO}_{3} / 0.1 \mathrm{M}$ HF followed by analysis by gamma PHA, ICP-MS and ICP-ES.

Note that the dissolution of purified $\mathrm{PuO}_{2}$ samples in $12 \mathrm{M} \mathrm{HNO}_{3} / 0.1 \mathrm{M}$ HF occurred in virgin polypropylene vessels within a hot block at $95^{\circ} \mathrm{C}$ for $3 \mathrm{~h}$. After the 3-h dissolution, personnel detected no visible solids in the solutions. Samples of the dissolved $\mathrm{PuO}_{2}$ were analyzed directly as well as after removal of Pu to enable lower detection limits. For these dissolved $\mathrm{PuO}_{2}$ samples, several measures were taken to reduce the levels of contaminants introduced by the Pu removal method described earlier, which was used for the anion exchange product solution. ${ }^{6}$ The nitric acid used in the improved process was spectroscopy grade (Optima) stocks as opposed to ACS grade (reagent) stocks. The use of sodium nitrite was eliminated from the process, as it was expected that the bulk of the plutonium was already in the tetravalent state. Finally, the first $20 \mathrm{vol} \%$ of the sample load solution was used as a rinse to purify the resin bed. The first 20 vol \% aliquot that flowed through the resin beds was discarded. The remaining $80 \mathrm{vol} \%$ of the sample load solution was then purified by contacting it through the rinsed resin beds prior to submitting for further analyses by ICP-MS.

For the ICP-ES analysis of purified, dissolved $\mathrm{PuO}_{2}$, the same improvements were used - higher purity acid and use of the first $20 \mathrm{vol} \%$ of the solution to rinse the resin. For these ICP-ES solutions, however, resin beds of 2.2-mL cartridge volumes of TEVA $^{\circledR}$ were used to extract tetravalent plutonium from the sample solutions.

\subsection{Results and Discussion}

\subsection{Plutonium Purification by Anion Exchange}

Analysis of the hearts cut by ICP-MS measured $45.6 \mathrm{~g} / \mathrm{L}$ for Masses $239-241$ and a ${ }^{239} \mathrm{Pu}$ enrichment of $94 \%$. Gamma spectroscopy analysis measured $42.1 \mathrm{~g} / \mathrm{L}{ }^{239} \mathrm{Pu}$. Factoring for the enrichment measured by ICP-MS, the total $\mathrm{Pu}$ concentration determined using gamma spectroscopy was $44.8 \mathrm{~g} / \mathrm{L}$. Free acid analysis measured $1.23 \mathrm{M} \mathrm{H}^{+}$. Ion chromatography measurement reported fluoride $<10 \mathrm{mg} / \mathrm{L}$, chloride $<10 \mathrm{mg} / \mathrm{L}$ and nitrate $=1.77 \mathrm{M}$. In this case, 
the analyses confirm one another. The gamma analysis of $44.8 \mathrm{~g} \mathrm{Pu} / \mathrm{L}$ converts to $0.19 \mathrm{M} \mathrm{Pu}$. It is expected that the $\mathrm{Pu}$ is present as $\mathrm{Pu}(\mathrm{IV})$, which is associated with four nitrate ions per $\mathrm{Pu}$ ion, yielding $0.75 \mathrm{M}$ nitrate complexing the Pu. Combining the free acid (nitric acid) result of $1.23 \mathrm{M}$ with the $0.75 \mathrm{M}$ nitrate complexing the Pu yields an expected total nitrate of $1.98 \mathrm{M}$. The ion chromatography analysis of total nitrate is within $12 \%$ of this prediction.

Analytical results from the anion exchange column experiment are provided in Appendix A, and generally confirm expectations concerning resin performance. A plot of the $\mathrm{Pu}$ and ${ }^{241} \mathrm{Am}$ content of the solution exiting the resin column is shown in Figure 3-1, using average feed concentrations of $4.7 \mathrm{~g} \mathrm{Pu} / \mathrm{L}$ and $0.3 \mathrm{~g} \mathrm{Am} / \mathrm{L}$ for comparison. Because the Pu concentration was below the detection limit for gamma spectroscopy for the first six wash bottles, the data from ICP-MS were plotted. Thus, the slight increase in Pu concentration observed as loading ended and washing began may have been due in part to switching from gamma to ICP-MS values, as ICP-MS values are reported at $\pm 20 \%$. During both loading and wash cycles, the Pu concentration exiting the column increases, which is expected due to the limited amount of open sites on the resin for Pu sorption. Loading of the Primary Feed proceeded at nominally $17 \mathrm{mg} \mathrm{Pu} / \mathrm{min} / \mathrm{cm}^{2}$, using the average flow rate. Then, after the first liter $(0.68 \mathrm{BV})$ of wash, the volumetric flow rate increased by a factor of two for the remaining $9.52 \mathrm{BV}$ of wash. In Figure 3-1, elution begins at 21.9 BVs and the Hearts cut occurs from 22.5 to 23.7 BVs.

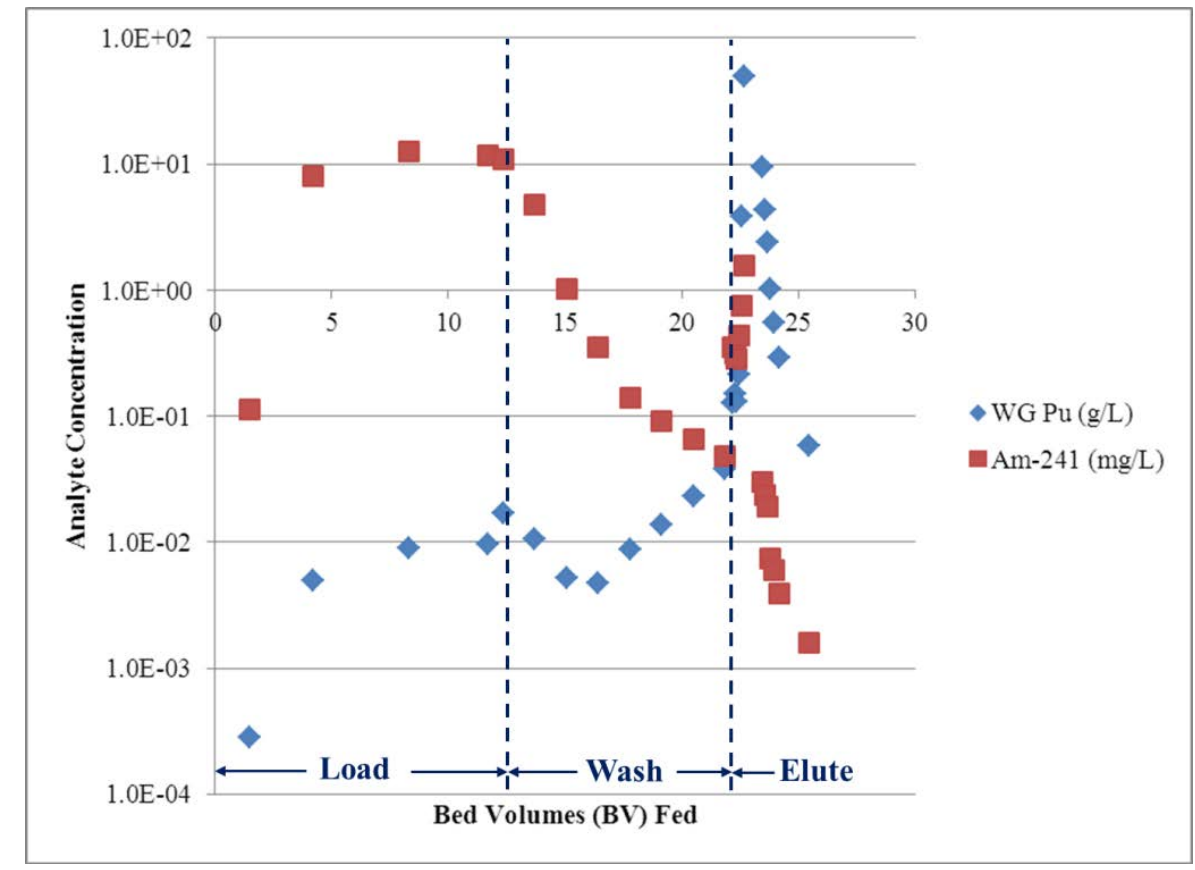

Figure 3-1. Pu and ${ }^{241} \mathrm{Am}$ Released from Resin Column

The elution profile for the column experiment is provided in Figure 3-2. The Heads cut begins at $0 \mathrm{BV}$. The Hearts cut begins at $0.68 \mathrm{BV}$ and ends at $1.80 \mathrm{BV}$. Figure $3-2$ shows that a minor amount of entrapped ${ }^{241} \mathrm{Am}$ releases as the Pu elutes. This behavior is similar to what has been observed with boron and gadolinium. ${ }^{3}$ 
SRNL-STI-2012-00422

Revision 0

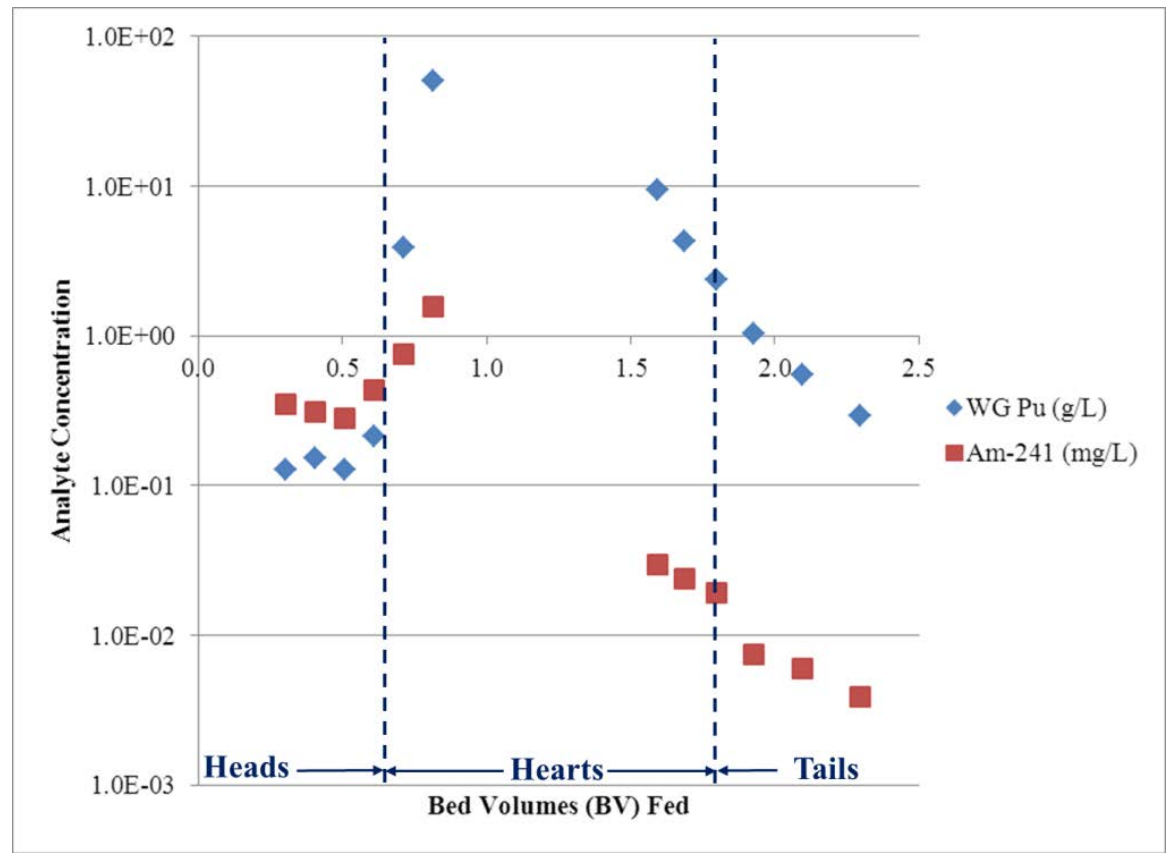

Figure 3-2. Pu and ${ }^{241} \mathrm{Am}$ Elution Profile

This experiment included $\sim 10 \mathrm{BV}$ of wash, and the Pu product solution was relatively pure, as shown in Table 3-1 and 3-2. Also shown in these tables are the concentration profiles of the various elements during column washing with $8 \mathrm{M} \mathrm{HNO}_{3}$.

Table 3-1. Sample Analyses by ICP-ES

\begin{tabular}{|c|c|c|c|c|c|c|c|c|c|c|c|}
\hline Element & $\begin{array}{c}\text { Feed } \\
\text { Item } 1 \\
(\mathrm{mg} / \mathrm{L}) \\
\end{array}$ & $\begin{array}{c}\text { Feed } \\
\text { Item } 4 \\
(\mathrm{mg} / \mathrm{L})\end{array}$ & $\begin{array}{c}\text { Wash } 1 \\
(\mathrm{mg} / \mathrm{L})\end{array}$ & $\begin{array}{r}\text { Wash } 2 \\
(\mathrm{mg} / \mathrm{L})\end{array}$ & $\begin{array}{l}\text { Wash } 3 \\
(\mathrm{mg} / \mathrm{L})\end{array}$ & $\begin{array}{c}\text { Wash } \\
4 \\
(\mathrm{mg} / \mathrm{L}) \\
\end{array}$ & $\begin{array}{l}\text { Wash } 5 \\
\text { (mg/L) } \\
\end{array}$ & $\begin{array}{l}\text { Wash } 6 \\
(\mathrm{mg} / \mathrm{L})\end{array}$ & $\begin{array}{l}\text { Wash } 7 \\
\text { (mg/L) }\end{array}$ & $\begin{array}{c}\text { Wash } 8 \\
(\mathrm{mg} / \mathrm{L})\end{array}$ & $\begin{array}{c}\text { Product } \\
(\mathrm{mg} / \mathrm{L})\end{array}$ \\
\hline $\mathrm{Al}$ & 44.6 & 4320 & 3760 & 262 & 4.08 & 1.65 & 1.47 & 0.703 & $<0.599$ & $<0.599$ & $<5.99$ \\
\hline B & $<5.7$ & 1110 & 1030 & 94.1 & 1.95 & 0.864 & 0.635 & 0.411 & 0.209 & 0.217 & $<5.7$ \\
\hline $\mathrm{Ba}$ & 1.49 & 1.83 & 1.43 & 0.215 & 0.101 & 0.272 & 5.06 & 0.238 & 0.108 & $<0.097$ & $<1.1$ \\
\hline $\mathrm{Be}$ & 5.1 & 1.93 & 1.7 & 0.119 & $<0.008$ & $<0.008$ & $<0.008$ & $<0.008$ & $<0.008$ & $<0.008$ & $<0.08$ \\
\hline $\mathrm{Ca}$ & 37.9 & 44.7 & 34.9 & 3.07 & 0.382 & 0.307 & 1.07 & 0.338 & 0.156 & 0.262 & $<7$ \\
\hline $\mathrm{Cd}$ & $<1.21$ & $<1.21$ & $<0.121$ & $<0.121$ & $<0.121$ & $<0.121$ & $<0.121$ & $<0.121$ & $<0.121$ & $<0.121$ & $<3.6$ \\
\hline $\mathrm{Ce}$ & $<7.91$ & $<7.91$ & 6.26 & 6.24 & 4.8 & 3.81 & 2.43 & 1.96 & 1.28 & 0.815 & $<12.4$ \\
\hline Co & $<1.83$ & $<1.83$ & 0.548 & $<0.183$ & $<0.183$ & $<0.183$ & $<0.183$ & $<0.183$ & $<0.183$ & $<0.183$ & $<1.83$ \\
\hline $\mathrm{Cr}$ & 74.2 & 42.2 & 35.3 & 2.55 & 0.077 & $<0.06$ & $<0.06$ & $<0.06$ & $<0.06$ & $<0.06$ & $<2.16$ \\
\hline $\mathrm{Cu}$ & 8.6 & 9.41 & 7.01 & 0.621 & $<0.186$ & $<0.186$ & $<0.186$ & $<0.186$ & $<0.186$ & $<0.186$ & $<8.52$ \\
\hline $\mathrm{Fe}$ & 4630 & 1210 & 1050 & 82.3 & 1.81 & 1.06 & 0.844 & 1.3 & 0.252 & 0.381 & $<3.94$ \\
\hline$\overline{\mathrm{Gd}}$ & $<3.84$ & $<3.84$ & $<1.92$ & $<0.192$ & $<0.192$ & $<0.192$ & $<0.192$ & $<0.192$ & $<0.192$ & $<0.192$ & $<1.92$ \\
\hline $\mathrm{K}$ & 2950 & 1810 & 1600 & 125 & $<3.4$ & $<3.4$ & $<3.4$ & $<3.4$ & $<3.4$ & $<3.4$ & $<76.4$ \\
\hline $\mathrm{Mg}$ & 121 & 40.1 & 33.3 & 2.39 & 0.167 & 0.122 & 1.28 & 0.192 & 0.028 & 0.053 & $<0.11$ \\
\hline Mn & 25.3 & 7.1 & 5.6 & 0.435 & $<0.034$ & $<0.034$ & $<0.034$ & $<0.034$ & $<0.034$ & $<0.034$ & $<3.4$ \\
\hline Mo & $<16.4$ & $<16.4$ & 3.67 & $<1.12$ & $<1.12$ & $<1.12$ & $<1.12$ & $<1.12$ & $<1.12$ & $<1.12$ & $<16.4$ \\
\hline $\mathrm{Na}$ & 24500 & 14300 & 11200 & 782 & 14.1 & 5.63 & 8.84 & 2.44 & 0.977 & 1.07 & $<23$ \\
\hline $\mathrm{Ni}$ & 79.3 & 95.4 & 78 & 5.58 & $<0.37$ & $<0.37$ & $<0.37$ & $<0.37$ & $<0.37$ & $<0.37$ & $<3.7$ \\
\hline $\mathrm{Pb}$ & $<17.6$ & $<17.6$ & 6.18 & $<1.76$ & $<1.76$ & $<1.76$ & $<1.76$ & $<1.76$ & $<1.76$ & $<1.76$ & $<17.6$ \\
\hline $\mathrm{S}$ & 6690 & $<300$ & $<30$ & $<30$ & $<30$ & $<30$ & $<30$ & $<30$ & $<30$ & $<30$ & $<30$ \\
\hline Si & 70.7 & $<21.5$ & 5.46 & 1.9 & 0.897 & 0.902 & 0.852 & 0.991 & 2.29 & 1.56 & $<21.5$ \\
\hline Sn & $<14.7$ & $<14.7$ & 5.23 & $<1.47$ & $<1.47$ & $<1.47$ & $<1.47$ & $<<1.47$ & $<1.47$ & $<<1.47$ & $<29.4$ \\
\hline $\mathrm{Sr}$ & $<0.2$ & $<0.2$ & 0.167 & 0.017 & $<0.015$ & $<0.015$ & 0.121 & $<0.015$ & $<0.015$ & $<0.015$ & $<0.1$ \\
\hline $\mathrm{Ti}$ & 1.59 & 1.29 & 1.32 & 0.085 & $<0.04$ & $<0.04$ & $<0.04$ & $<0.04$ & $<0.04$ & $<0.04$ & $<0.4$ \\
\hline $\mathrm{Zn}$ & 3.6 & 3.56 & 2.22 & 0.444 & 0.313 & 0.356 & 20.9 & 2.15 & 0.15 & 0.232 & $<1.31$ \\
\hline $\mathrm{Zr}$ & 192 & $<0.63$ & 0.587 & 0.109 & $<0.056$ & $<0.056$ & $<0.056$ & $<0.056$ & $<0.056$ & $<0.056$ & $<1.26$ \\
\hline
\end{tabular}

Note: highlighted cells indicate values below the method detection limit. 
Results in Tables 3-1 and 3-2 are for solutions without Pu removal. Later in this report, analyses of the Product solution after removal of Pu are reported and evaluated. Analytical and operating data from the anion exchange column test, such as radioactive dose rates which are largely due to ${ }^{241} \mathrm{Am}$, are included in Appendix Tables A-1 and A-2. In addition, in Appendix Tables A-3 and A-4, results for Feed Item 4, the Primary Feed, are shown next to results of the Primary Feed Raffinate sample, which is essentially the Primary Feed after removal of $\mathrm{Pu}$ by the anion exchange column. The results show very good agreement between the two analyses.

Table 3-2. Sample Analyses by ICP-MS

\begin{tabular}{|c|c|c|c|c|c|c|c|c|c|c|c|}
\hline $\begin{array}{c}\text { Mass } \\
\text { Number }\end{array}$ & $\begin{array}{c}\text { Feed } \\
\text { Item } 1 \\
(\mathrm{mg} / \mathrm{L})\end{array}$ & $\begin{array}{c}\text { Feed } \\
\text { Item } 4 \\
(\mathrm{mg} / \mathrm{L})\end{array}$ & $\begin{array}{l}\text { Wash } 1 \\
(\mathrm{mg} / \mathrm{L})\end{array}$ & $\begin{array}{l}\text { Wash } 2 \\
(\mathrm{mg} / \mathrm{L})\end{array}$ & $\begin{array}{l}\text { Wash } 3 \\
(\mathrm{mg} / \mathrm{L})\end{array}$ & $\begin{array}{l}\text { Wash } 4 \\
(\mathrm{mg} / \mathrm{L})\end{array}$ & $\begin{array}{c}\text { Wash } 5 \\
(\mathrm{mg} / \mathrm{L})\end{array}$ & $\begin{array}{l}\text { Wash } 6 \\
(\mathrm{mg} / \mathrm{L})\end{array}$ & $\begin{array}{c}\text { Wash } 7 \\
\text { (mg/L) }\end{array}$ & $\begin{array}{l}\text { Wash } 8 \\
\text { (mg/L) }\end{array}$ & $\begin{array}{c}\text { Product } \\
(\mathrm{mg} / \mathrm{L})\end{array}$ \\
\hline 59 & 1.15 & 0.774 & 0.575 & 0.047 & $<0.020$ & $<0.020$ & 0.023 & $<0.020$ & $<0.020$ & $<0.020$ & $<0.020$ \\
\hline 63 & 3.01 & 6.16 & 4.35 & 0.356 & $<0.095$ & $<0.095$ & $<0.095$ & $<0.095$ & $<0.095$ & $<0.095$ & $<0.095$ \\
\hline 65 & 0.980 & 2.74 & 1.88 & 0.053 & $<0.035$ & $<0.035$ & $<0.035$ & $<0.035$ & $<0.035$ & $<0.035$ & $<0.035$ \\
\hline 69 & 45.5 & 61.5 & 55.9 & 3.53 & 0.052 & 0.030 & 0.039 & $<0.025$ & $<0.025$ & $<0.025$ & $<0.025$ \\
\hline 71 & 31.4 & 43.9 & 36.9 & 2.40 & 0.035 & 0.022 & $<0.015$ & $<0.015$ & $<0.015$ & $<0.015$ & $<0.015$ \\
\hline 88 & 0.304 & 0.209 & 0.298 & 0.067 & 0.061 & 0.058 & 0.191 & 0.068 & 0.051 & 0.062 & $<0.020$ \\
\hline 89 & 0.513 & 0.622 & 0.455 & 0.042 & $<0.015$ & $<0.015$ & 0.051 & $<0.015$ & $<0.015$ & $<0.015$ & $<0.015$ \\
\hline 90 & 131 & 0.661 & 0.384 & 0.085 & 0.026 & 0.033 & 0.025 & 0.033 & $<0.020$ & 0.029 & $<0.02$ \\
\hline 91 & 26.6 & 0.163 & 0.101 & 0.022 & $<0.010$ & $<0.010$ & $<0.010$ & $<0.010$ & $<0.010$ & $<0.010$ & $<0.010$ \\
\hline 92 & 44.2 & 0.955 & 0.626 & 0.126 & 0.018 & 0.017 & $<0.015$ & $<0.015$ & $<0.015$ & $<0.015$ & $<0.015$ \\
\hline 94 & 46.2 & 0.654 & 0.414 & 0.084 & 0.016 & $<0.015$ & $<0.015$ & 0.015 & $<0.015$ & $<0.015$ & $<0.015$ \\
\hline 95 & 0.671 & 0.752 & 0.600 & 0.092 & $<0.015$ & $<0.015$ & $<0.015$ & $<0.015$ & $<0.015$ & $<0.015$ & $<0.015$ \\
\hline 96 & 8.22 & 0.780 & 0.614 & 0.093 & 0.016 & $<0.010$ & $<0.010$ & $<0.010$ & $<0.010$ & $<0.010$ & $<0.010$ \\
\hline 97 & 0.374 & 0.445 & 0.340 & 0.052 & $<0.015$ & $<0.015$ & $<0.015$ & $<0.015$ & $<0.015$ & $<0.015$ & $<0.015$ \\
\hline 98 & 1.04 & 1.08 & 0.836 & 0.149 & $<0.010$ & $<0.010$ & $<0.010$ & $<0.010$ & $<0.010$ & $<0.010$ & $<0.010$ \\
\hline 100 & 0.414 & 0.478 & 0.335 & 0.057 & $<0.010$ & $<0.010$ & $<0.010$ & $<0.010$ & $<0.010$ & $<0.010$ & $<0.010$ \\
\hline 106 & 0.813 & $<0.200$ & $<0.015$ & $<0.015$ & $<0.015$ & $<0.015$ & $<0.015$ & $<0.015$ & $<0.015$ & $<0.015$ & $<0.015$ \\
\hline 107 & 0.275 & $<0.050$ & $<0.025$ & 0.029 & $<0.025$ & $<0.025$ & $<0.025$ & $<0.025$ & $<0.025$ & $<0.025$ & 0.070 \\
\hline 108 & 0.288 & $<0.050$ & $<0.010$ & $<0.010$ & $<0.010$ & $<0.010$ & $<0.010$ & $<0.010$ & $<0.010$ & $<0.010$ & $<0.010$ \\
\hline 110 & 0.379 & $<0.050$ & $<0.010$ & $<0.010$ & $<0.010$ & $<0.010$ & $<0.010$ & $<0.010$ & $<0.010$ & $<0.010$ & $<0.010$ \\
\hline 112 & 0.140 & 0.085 & 0.076 & $<0.010$ & $<0.010$ & $<0.010$ & $<0.010$ & $<0.010$ & $<0.010$ & $<0.010$ & $<0.010$ \\
\hline 114 & 0.127 & 0.105 & 0.053 & $<0.010$ & $<0.010$ & $<0.010$ & $<0.010$ & $<0.010$ & $<0.010$ & $<0.010$ & $<0.010$ \\
\hline 116 & 0.310 & 0.880 & 0.800 & 0.068 & $<0.015$ & $<0.015$ & $<0.015$ & $<0.015$ & $<0.015$ & $<0.015$ & $<0.015$ \\
\hline 117 & 0.181 & 0.429 & 0.398 & 0.043 & $<0.010$ & $<0.010$ & $<0.010$ & $<0.010$ & $<0.010$ & $<0.010$ & $<0.010$ \\
\hline 118 & 0.483 & 1.45 & 1.315 & 0.142 & 0.038 & $<0.023$ & $<0.020$ & $<0.020$ & $<0.020$ & $<0.020$ & $<0.020$ \\
\hline 119 & 1.37 & 1.03 & 0.444 & 0.042 & $<0.025$ & $<0.025$ & $<0.025$ & $<0.025$ & $<0.025$ & $<0.025$ & 1.43 \\
\hline 120 & 20.4 & 10.9 & 1.66 & 0.141 & 0.018 & 0.019 & 0.024 & 0.038 & 0.054 & 0.083 & 122 \\
\hline 121 & 0.275 & 0.103 & 0.087 & 0.036 & 0.014 & 0.012 & $<0.010$ & $<0.010$ & $<0.010$ & $<0.010$ & 0.218 \\
\hline 122 & 0.135 & 0.357 & 0.344 & 0.031 & $<0.010$ & $<0.010$ & $<0.010$ & $<0.010$ & $<0.010$ & $<0.010$ & $<0.010$ \\
\hline 123 & 0.194 & $<0.100$ & $<0.045$ & $<0.045$ & $<0.045$ & $<0.045$ & $<0.045$ & $<0.045$ & $<0.045$ & $<0.045$ & $<0.045$ \\
\hline 124 & 0.209 & 0.564 & 0.523 & 0.042 & $<0.015$ & $<0.015$ & $<0.015$ & $<0.015$ & $<0.015$ & $<0.015$ & $<0.015$ \\
\hline 135 & 0.077 & 0.099 & 0.086 & 0.011 & $<0.010$ & $<0.010$ & 0.048 & $<0.010$ & $<0.010$ & $<0.010$ & $<0.010$ \\
\hline 137 & 0.104 & 0.227 & 0.160 & 0.018 & $<0.010$ & $<0.010$ & 0.084 & $<0.010$ & $<0.010$ & $<0.010$ & $<0.010$ \\
\hline 138 & 0.671 & 1.253 & 0.913 & 0.116 & 0.029 & 0.032 & 0.561 & 0.033 & $<0.020$ & $<0.020$ & $<0.020$ \\
\hline
\end{tabular}

Note: highlighted cells indicate values below the method detection limit 
Table 3-2. Sample Analyses by ICP-MS (cont'd)

\begin{tabular}{|c|c|c|c|c|c|c|c|c|c|c|c|}
\hline $\begin{array}{c}\text { Mass } \\
\text { Number }\end{array}$ & $\begin{array}{c}\text { Feed } \\
\text { Item } 1 \\
(\mathrm{mg} / \mathrm{L})\end{array}$ & $\begin{array}{c}\text { Feed } \\
\text { Item } 4 \\
(\mathrm{mg} / \mathrm{L})\end{array}$ & $\begin{array}{c}\text { Wash } \\
1 \\
(\mathrm{mg} / \mathrm{L})\end{array}$ & $\begin{array}{c}\text { Wash } \\
2 \\
(\mathrm{mg} / \mathrm{L})\end{array}$ & $\begin{array}{c}\text { Wash } \\
3 \\
(\mathrm{mg} / \mathrm{L})\end{array}$ & $\begin{array}{l}\text { Wash } 4 \\
\text { (mg/L) }\end{array}$ & $\begin{array}{l}\text { Wash } 5 \\
(\mathrm{mg} / \mathrm{L})\end{array}$ & $\begin{array}{l}\text { Wash } 6 \\
(\mathrm{mg} / \mathrm{L})\end{array}$ & $\begin{array}{l}\text { Wash } 7 \\
\text { (mg/L) }\end{array}$ & $\begin{array}{c}\text { Wash } 8 \\
(\mathrm{mg} / \mathrm{L})\end{array}$ & $\begin{array}{c}\text { Product } \\
\text { (mg/L) }\end{array}$ \\
\hline 140 & 1.25 & 5.83 & 5.45 & 5.16 & 3.76 & 2.87 & 2.08 & 1.60 & 1.14 & 0.648 & 5.44 \\
\hline 142 & 0.179 & 0.777 & 0.700 & 0.628 & 0.459 & 0.371 & 0.280 & 0.194 & 0.143 & 0.074 & 0.735 \\
\hline 144 & $<0.050$ & 0.08 & $<0.010$ & $<0.010$ & $<0.010$ & $<0.010$ & 0.017 & $<0.010$ & $<0.010$ & $<0.010$ & $<0.010$ \\
\hline 146 & $<0.050$ & 0.05 & $<0.010$ & $<0.010$ & $<0.010$ & $<0.010$ & 0.013 & $<0.010$ & $<0.010$ & $<0.010$ & $<0.010$ \\
\hline 155 & 0.113 & $<0.050$ & $<0.010$ & $<0.010$ & $<0.010$ & $<0.010$ & $<0.010$ & $<0.010$ & $<0.010$ & $<0.010$ & $<0.010$ \\
\hline 156 & 0.170 & 0.099 & 0.087 & 0.075 & 0.058 & 0.036 & 0.039 & 0.023 & 0.023 & 0.011 & 0.122 \\
\hline 157 & 0.128 & $<0.050$ & $<0.015$ & $<0.015$ & $<0.015$ & $<0.015$ & $<0.015$ & $<0.015$ & $<0.015$ & $<0.015$ & $<0.015$ \\
\hline 158 & 0.203 & $<0.050$ & 0.017 & 0.014 & 0.015 & 0.011 & 0.013 & 0.011 & $<0.010$ & $<0.010$ & $<0.010$ \\
\hline 160 & 0.163 & $<0.050$ & $<0.010$ & $<0.010$ & $<0.010$ & $<0.010$ & $<0.010$ & $<0.010$ & $<0.010$ & $<0.010$ & $<0.010$ \\
\hline 166 & 0.370 & $<0.050$ & 0.034 & $<0.010$ & $<0.010$ & $<0.010$ & $<0.010$ & $<0.010$ & $<0.010$ & $<0.010$ & $<0.010$ \\
\hline 167 & 0.238 & $<0.050$ & 0.019 & $<0.010$ & $<0.010$ & $<0.010$ & $<0.010$ & $<0.010$ & $<0.010$ & $<0.010$ & $<0.010$ \\
\hline 168 & 0.264 & $<0.050$ & 0.023 & $<0.010$ & $<0.010$ & $<0.010$ & $<0.010$ & $<0.010$ & $<0.010$ & $<0.010$ & $<0.010$ \\
\hline 170 & 0.150 & $<0.050$ & 0.016 & $<0.010$ & $<0.010$ & $<0.010$ & $<0.010$ & $<0.010$ & $<0.010$ & $<0.010$ & $<0.010$ \\
\hline 176 & 0.070 & $<0.050$ & $<0.010$ & $<0.010$ & $<0.010$ & $<0.010$ & $<0.010$ & $<0.010$ & $<0.010$ & $<0.010$ & $<0.010$ \\
\hline 177 & 0.240 & $<0.050$ & $<0.010$ & $<0.010$ & $<0.010$ & $<0.010$ & $<0.010$ & $<0.010$ & $<0.010$ & $<0.010$ & $<0.010$ \\
\hline 178 & 0.349 & $<0.050$ & $<0.010$ & $<0.010$ & $<0.010$ & $<0.010$ & $<0.010$ & $<0.010$ & $<0.010$ & $<0.010$ & $<0.010$ \\
\hline 179 & 0.177 & $<0.050$ & $<0.010$ & $<0.010$ & $<0.010$ & $<0.010$ & $<0.010$ & $<0.010$ & $<0.010$ & $<0.010$ & $<0.010$ \\
\hline 180 & 0.473 & $<0.050$ & $<0.010$ & $<0.010$ & $<0.010$ & $<0.010$ & $<0.010$ & $<0.010$ & $<0.010$ & $<0.010$ & $<0.010$ \\
\hline 181 & 3.91 & 0.162 & 0.166 & 0.093 & 0.126 & 0.036 & 0.130 & 0.072 & 0.018 & $<0.010$ & $<0.010$ \\
\hline 182 & 6.25 & 0.851 & 0.654 & 0.151 & 0.045 & 0.032 & 0.022 & 0.020 & 0.016 & 0.016 & 0.092 \\
\hline 183 & 3.28 & 0.434 & 0.383 & 0.094 & 0.028 & 0.018 & 0.014 & 0.011 & 0.012 & 0.011 & $<0.010$ \\
\hline 184 & 6.92 & 1.05 & 0.762 & 0.181 & 0.048 & 0.037 & 0.029 & 0.029 & 0.022 & 0.032 & 0.104 \\
\hline 186 & 6.81 & 0.922 & 0.684 & 0.167 & 0.046 & 0.032 & 0.031 & 0.024 & 0.021 & $<0.015$ & 0.109 \\
\hline 206 & 0.254 & 0.861 & 0.829 & 0.196 & 0.017 & $<0.010$ & 0.011 & $<0.010$ & $<0.010$ & $<0.010$ & $<0.010$ \\
\hline 207 & 0.245 & 0.809 & 0.731 & 0.166 & 0.013 & $<0.010$ & 0.011 & $<0.010$ & $<0.010$ & $<0.010$ & $<0.010$ \\
\hline 208 & 0.581 & 2.05 & 1.71 & 0.388 & 0.038 & $<0.015$ & 0.021 & 0.026 & $<0.015$ & $<0.015$ & $<0.015$ \\
\hline 234 & 0.639 & 0.166 & 0.212 & 0.208 & 0.143 & 0.081 & 0.051 & 0.042 & 0.019 & 0.012 & 0.070 \\
\hline 235 & 30.8 & 6.04 & 7.98 & 8.30 & 5.06 & 3.00 & 1.89 & 1.12 & 0.649 & 0.313 & 1.54 \\
\hline 236 & 2.46 & 1.22 & 1.53 & 1.59 & 0.994 & 0.630 & 0.362 & 0.213 & 0.120 & 0.062 & 0.336 \\
\hline 237 & 1.06 & 0.621 & 0.126 & 0.128 & 0.092 & 0.07 & 0.04 & 0.04 & 0.03 & 0.03 & 5.58 \\
\hline 238 & 4.07 & 1.68 & 0.937 & 0.955 & 0.656 & 0.375 & 0.248 & 0.142 & 0.083 & 0.041 & 5.38 \\
\hline 239 & 7400 & 4416 & 6.44 & 5.90 & 3.95 & 4.13 & 8.12 & 13.0 & 18.2 & 25.9 & 42900 \\
\hline 240 & 483 & 283 & 0.392 & 0.367 & 0.234 & 0.260 & 0.48 & 0.79 & 1.09 & 1.57 & 2640 \\
\hline 241 & 23.5 & 15.0 & 10.1 & 4.29 & 0.979 & 0.286 & 0.136 & 0.096 & 0.082 & 0.051 & 34.4 \\
\hline
\end{tabular}

Note: highlighted cells indicate values below the method detection limit

\subsection{Precipitation}

Analysis of the well-mixed anion exchange Pu product solution showed $1.23 \mathrm{M}$ free acid and $44.8 \mathrm{~g} \mathrm{Pu} / \mathrm{L}$. To increase the acidity to $1.5 \mathrm{M}, 100 \mathrm{~mL}$ of $7.0 \mathrm{M} \mathrm{HNO}_{3}$ were added to the remaining $1.75 \mathrm{~L}$ of $\mathrm{Pu}$ product solution. Analysis of the Adjusted Product solution showed 1.54 M free acid and $44.1 \mathrm{~g} \mathrm{Pu} / \mathrm{L}$. The Adjusted Product analysis yielded a total $\mathrm{Pu}$ mass (including samples) of $87.3 \mathrm{~g} \mathrm{Pu}$, which was $4 \%$ higher than the total Pu based on the nonadjusted Product, but within the reported uncertainty of $5.0 \%$ for gamma PHA analyses. Summaries of the precipitation conditions and results are shown in Table 3-3. and 3-4 Based on the Adjusted Product analyses, the excess oxalic acid for the Demo 1 precipitation batch was 0.09 $\mathrm{M}$, and that of the Demo 2 batch was $0.10 \mathrm{M}$, both within the proposed HB-Line operating range of $0.10 \pm 0.01 \mathrm{M}$ excess oxalic acid. 
Table 3-3. Precipitation Conditions

\begin{tabular}{||c|c|c|c|c|c|c||}
\hline Batch & $\begin{array}{c}\mathbf{4 4 . 1} \\
\mathbf{g} / \mathbf{L} \mathbf{P u}\end{array}$ & $\begin{array}{c}\mathbf{0 . 9} \mathbf{M} \\
\text { Oxalic }\end{array}$ & $\begin{array}{c}\text { Oxalic } \\
\text { acid } \\
\text { addition } \\
\text { time, } \mathbf{m i n}\end{array}$ & $\begin{array}{c}\text { Digestion } \\
\text { Time } \\
\mathbf{m L}\end{array}$ & $\begin{array}{c}\text { Wash } \\
\text { Solution }\end{array}$ & $\begin{array}{c}\text { Vacuum } \\
\text { Drying } \\
\text { Time } \\
\text { min }\end{array}$ \\
\hline Demo 1 & 944 & 540 & 43 & 5 & 0 & $50-60$ \\
\hline Demo 2 & 895 & 525 & 42 & 5 & 0 & 15 \\
\hline
\end{tabular}

Table 3-4. Precipitation Results

\begin{tabular}{||c|c|c|c|c||}
\hline Batch & $\begin{array}{c}\text { Pu in } \\
\text { Feed } \\
\text { g }\end{array}$ & $\begin{array}{c}\text { Pu } \\
\text { Oxalate } \\
\text { g }\end{array}$ & $\begin{array}{c}\text { Pu in } \\
\text { Filtrate }^{\dagger} \\
\text { g }\end{array}$ & $\begin{array}{c}\text { \% Pu Losses } \\
\text { to Filtrate }^{-1}\end{array}$ \\
\hline Demo 1 & 41.6 & 107.815 & 0.14 & 0.34 \\
\hline Demo 2 & 39.4 & 103.602 & 0.16 & 0.41 \\
\hline
\end{tabular}

${ }^{\dagger}$ Determined by gamma PHA with isotopic ratio by ICP-MS.

\subsection{Calcination}

Using a calcination temperature of $650{ }^{\circ} \mathrm{C}$, the $\mathrm{Pu}\left(\mathrm{C}_{2} \mathrm{O}_{4}\right)_{2} \bullet x \mathrm{H}_{2} \mathrm{O}$ samples were converted to $\mathrm{PuO}_{2}$. For the two calcinations, Appendix A (Figures A-1 and A-2) provides furnace and sample temperature profiles. Table 3-5 shows the masses of the initial oxalate material prior to calcination and the mass of the resulting $\mathrm{PuO}_{2}$ product, along with the theoretical dry amounts. Taking an average of the two batches, the actual Pu-oxalate mass was about $50 \%$ higher than the theoretical dry Pu-oxalate mass. This result indicates that about one-third of the $\mathrm{Pu}\left(\mathrm{C}_{2} \mathrm{O}_{4}\right)_{2}$ cake was water, including molecularly-bound waters of hydration and loosely-bound moisture.

Table 3-5. Mass Changes during Calcination

\begin{tabular}{||c|c|c|c|c|c||}
\hline \hline Batch & $\begin{array}{c}\text { Pu in } \\
\text { Feed } \\
\mathbf{g}\end{array}$ & $\begin{array}{c}\text { Dry Pu } \\
\text { Oxalate } \\
\text { (Theory) } \\
\mathbf{g}\end{array}$ & $\begin{array}{c}\text { Pu } \\
\text { Oxalate } \\
\text { (Actual) } \\
\mathbf{g}\end{array}$ & $\begin{array}{c}\mathbf{P u O}_{\mathbf{2}} \\
\text { (Theory) }\end{array}$ & $\begin{array}{c}\mathbf{P u O}_{2} \\
\text { (Actual) }\end{array}$ \\
\hline Demo 1 & 41.6 & 72.2 & 107.815 & 47.2 & $\mathbf{g}^{\dagger}$ \\
\hline Demo 2 & 39.4 & 68.4 & 103.602 & 44.7 & 43.7 \\
\hline \hline
\end{tabular}

These values reflect total product recovered, not including SEM samples.

After calcination for the specified time, the quartz crucible was removed from the furnace at temperature and cooled briefly before the sample was transferred to a jar. Exposure times are provided in Table 3-6. , along with ambient glovebox conditions. The jar was covered with a lid and placed into a secondary plastic bottle with a lid to minimize exposure to humid air.

Table 3-6. Glovebox Conditions after Calcination

\begin{tabular}{||c|c|c|c|c||}
\hline \multirow{2}{*}{$\begin{array}{c}\text { Calcination } \\
\text { Batch }\end{array}$} & \multirow{2}{*}{$\begin{array}{c}\text { Before or After } \\
\text { Calcination }\end{array}$} & \multicolumn{2}{|c|}{$\begin{array}{c}\text { Glovebox } \\
\text { Conditions }\end{array}$} & $\begin{array}{c}\text { Time for Cooling and } \\
\text { Transfer into Jar }\end{array}$ \\
\cline { 3 - 4 } & & $\begin{array}{c}\mathbf{T} \\
{ }^{\circ} \mathbf{C}\end{array}$ & $\begin{array}{c}\mathbf{R H} \\
\mathbf{\%}\end{array}$ & min \\
\hline \multirow{2}{*}{ Demo 1 } & Before & 23.7 & 55.7 & \multirow{2}{*}{15} \\
\cline { 2 - 4 } & After & NM & NM & \multirow{2}{*}{18} \\
\hline \multirow{2}{*}{ Demo 2 } & Before & 19.2 & 64.1 & \\
\cline { 2 - 4 } & After & 23.7 & 48.8 & \\
\hline
\end{tabular}

$\mathrm{NM}=$ not measured 
Photographs of the $\mathrm{Pu}$ oxalate in a quartz crucible prior to calcination and the $\mathrm{PuO}_{2}$ after calcination are shown in Figure 3-3. Though the photographs are from different batches, the Demo 2 batch contained nearly the same amount of Pu as Demo 1. Thus, Figure 3-3 depicts the volume (and color) change that occurs during calcination. The left portion of Figure 3-3 also shows the two thermocouples used for measuring cake temperature.

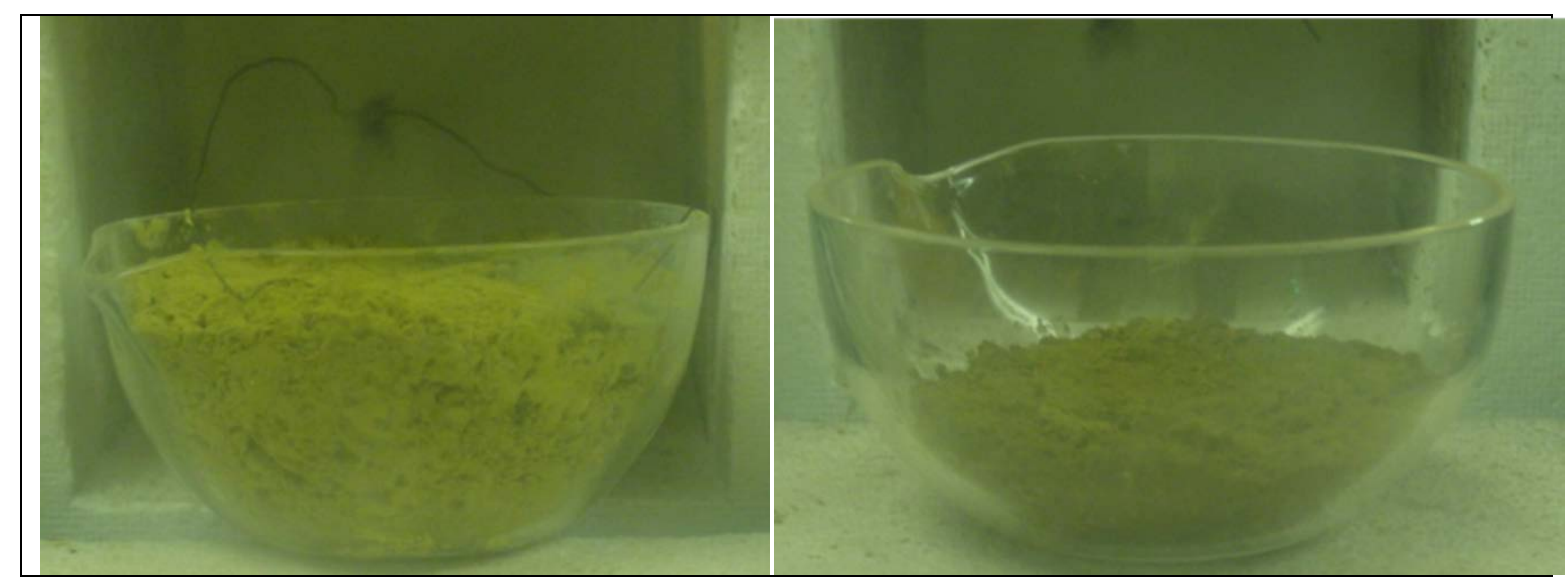

Figure 3-3. Left: Demo 1 Pu Oxalate; Right: Demo $2 \mathbf{P u O}_{2}$ after Calcination.

Samples of $\mathrm{PuO}_{2}$ from both batches were submitted for morphology characterization by SEM, as shown in Figure 3-4, Figure 3-5, and Figure 3-6.

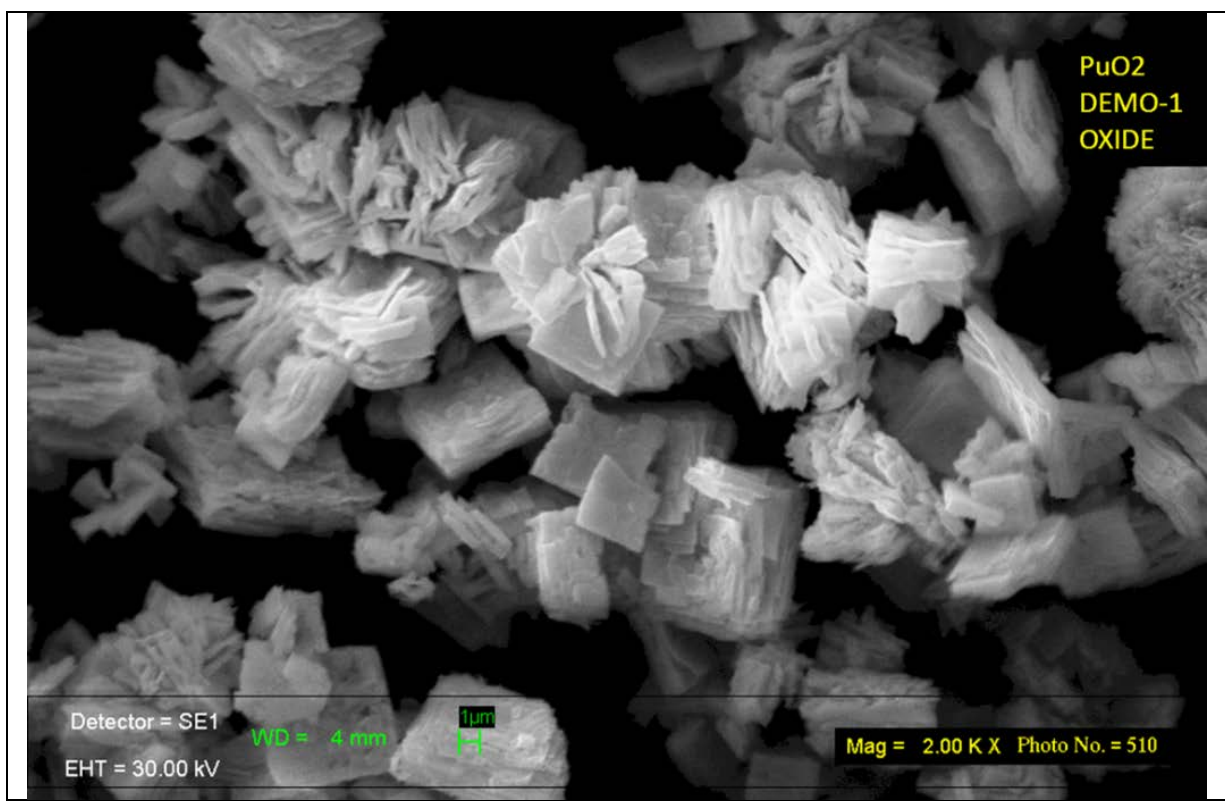

Figure 3-4. Typical SEM Results for Demo $1 \mathrm{PuO}_{2}$ 


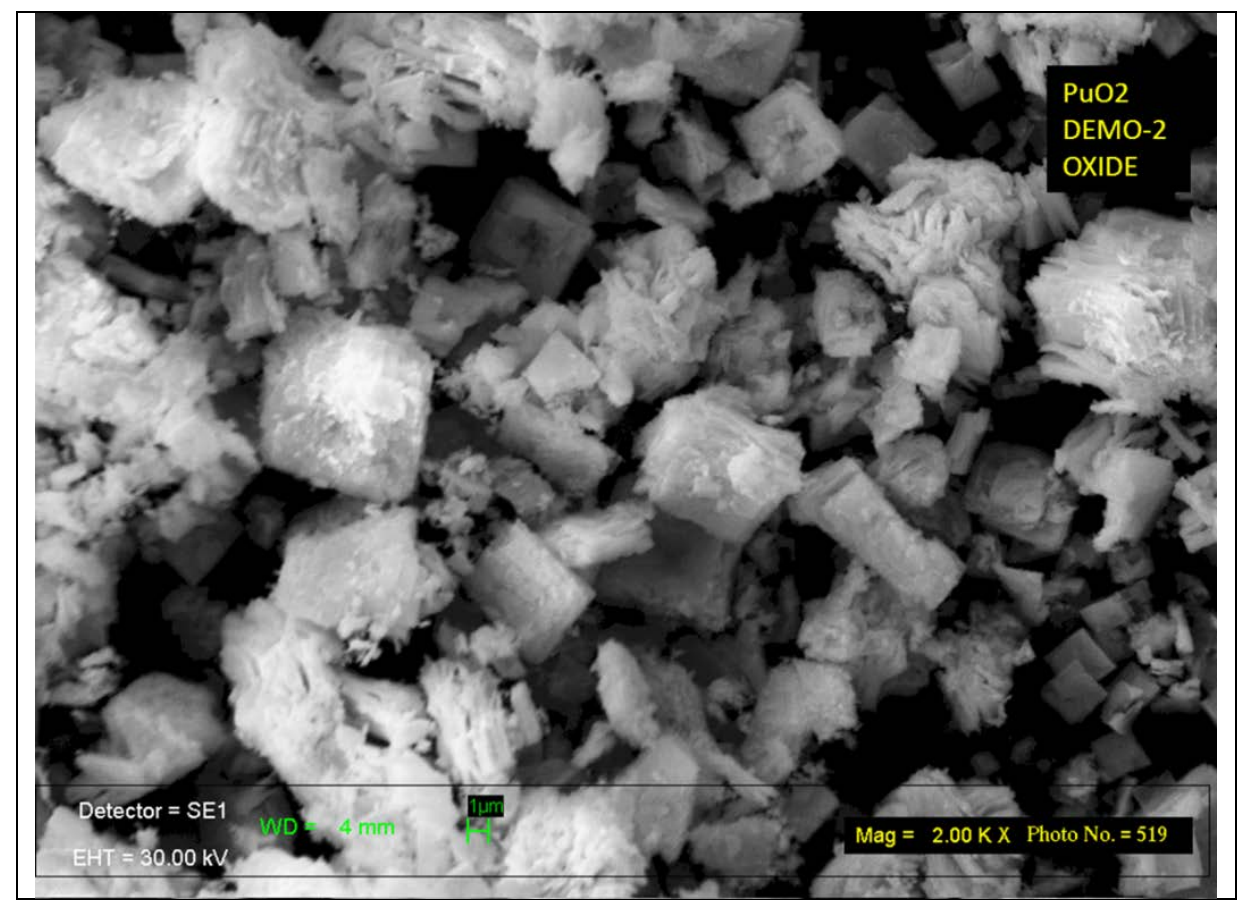

Figure 3-5. SEM Results for Demo $2 \mathrm{PuO}_{2}$, Showing Some Irregular Particles

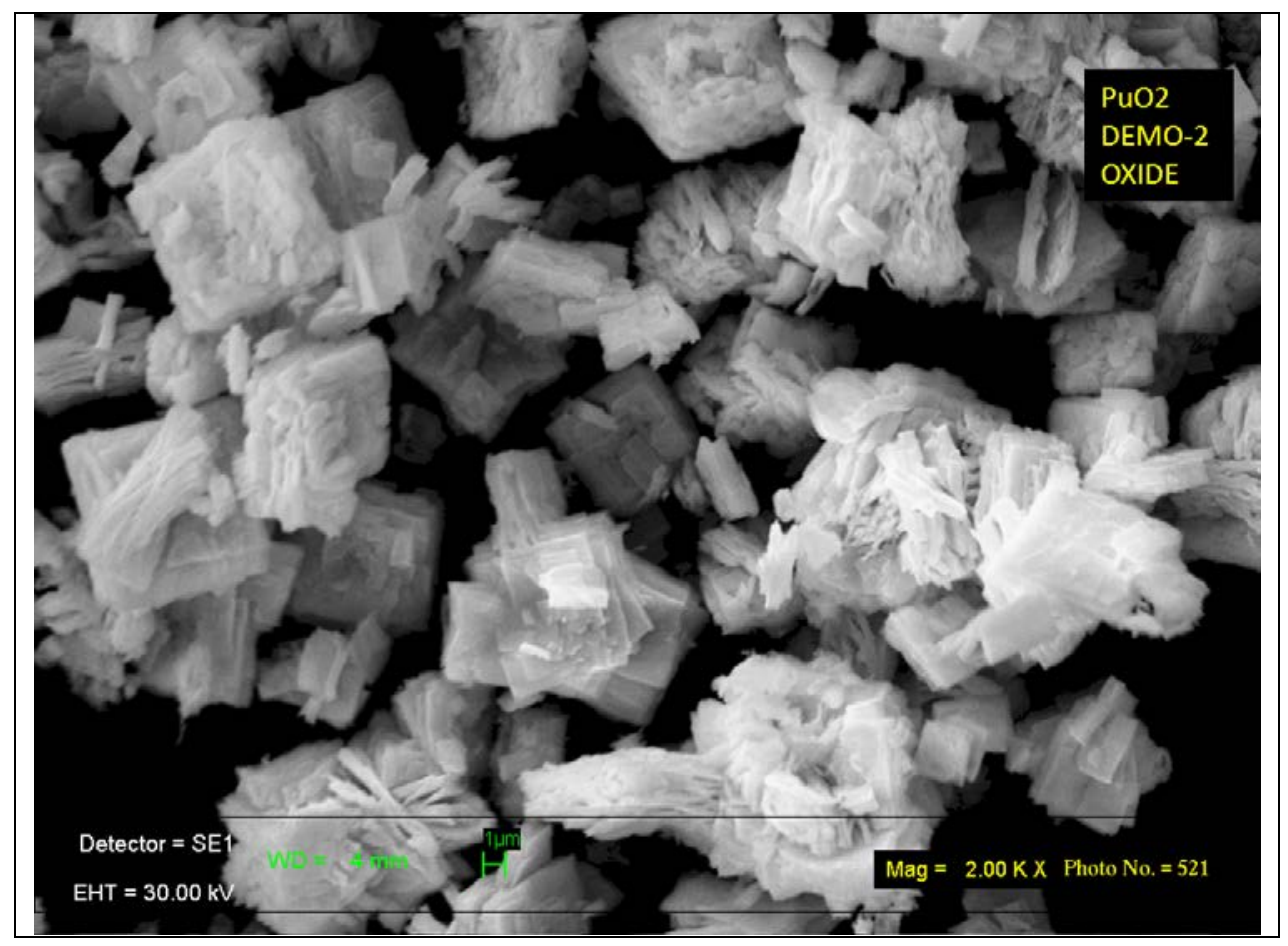

Figure 3-6. SEM Results for Demo $2 \mathrm{PuO}_{2}$, Showing Typical Particles

\subsubsection{Moisture Analysis by TGA-MS}

Typical TGA-MS plots for $\mathrm{PuO}_{2}$ samples produced in this study are shown in Figure 3-7, Figure 3-8, andFigure 3-9. 
TGA-MS: AFS-2 Integrated Demo Batch 1

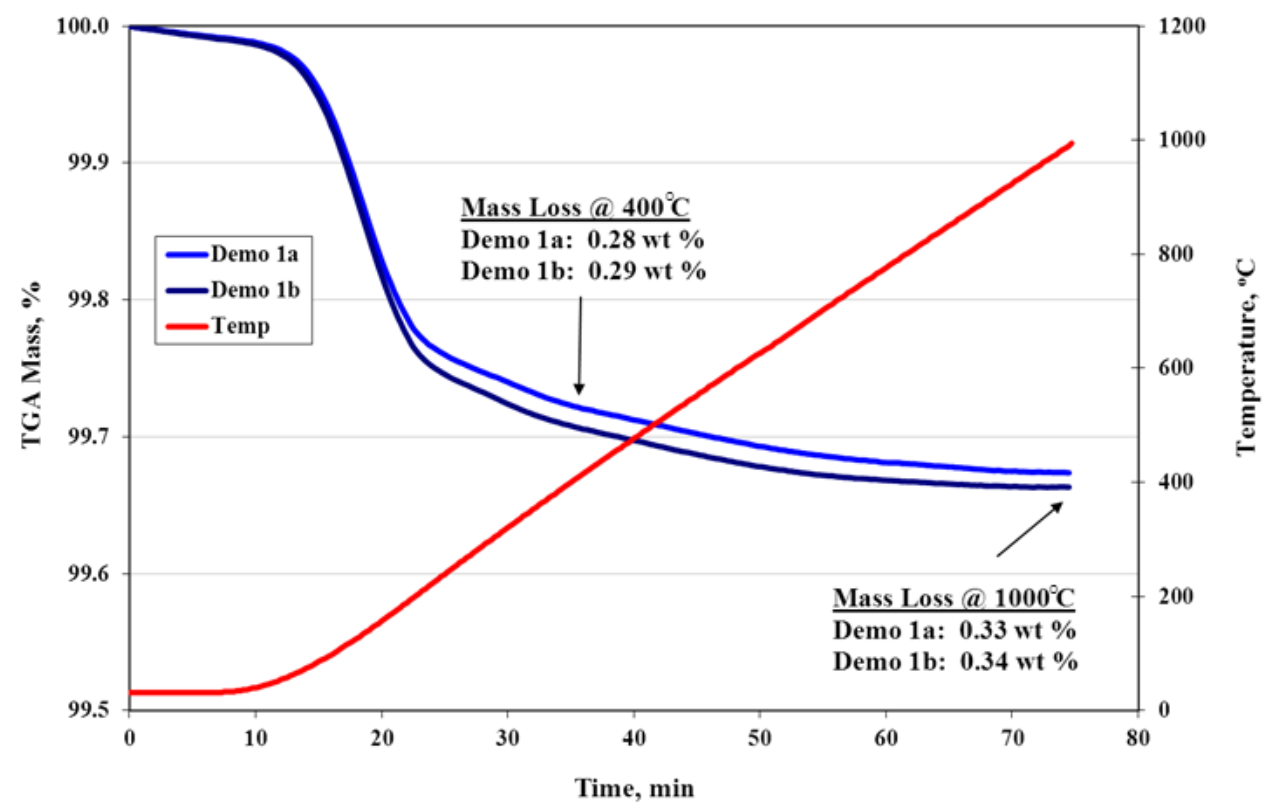

Figure 3-7. TGA Mass Measurements for Demo 1a and Demo 1b Samples

TGA-MS: FY2012 AFS2 (Demo 1 B402)

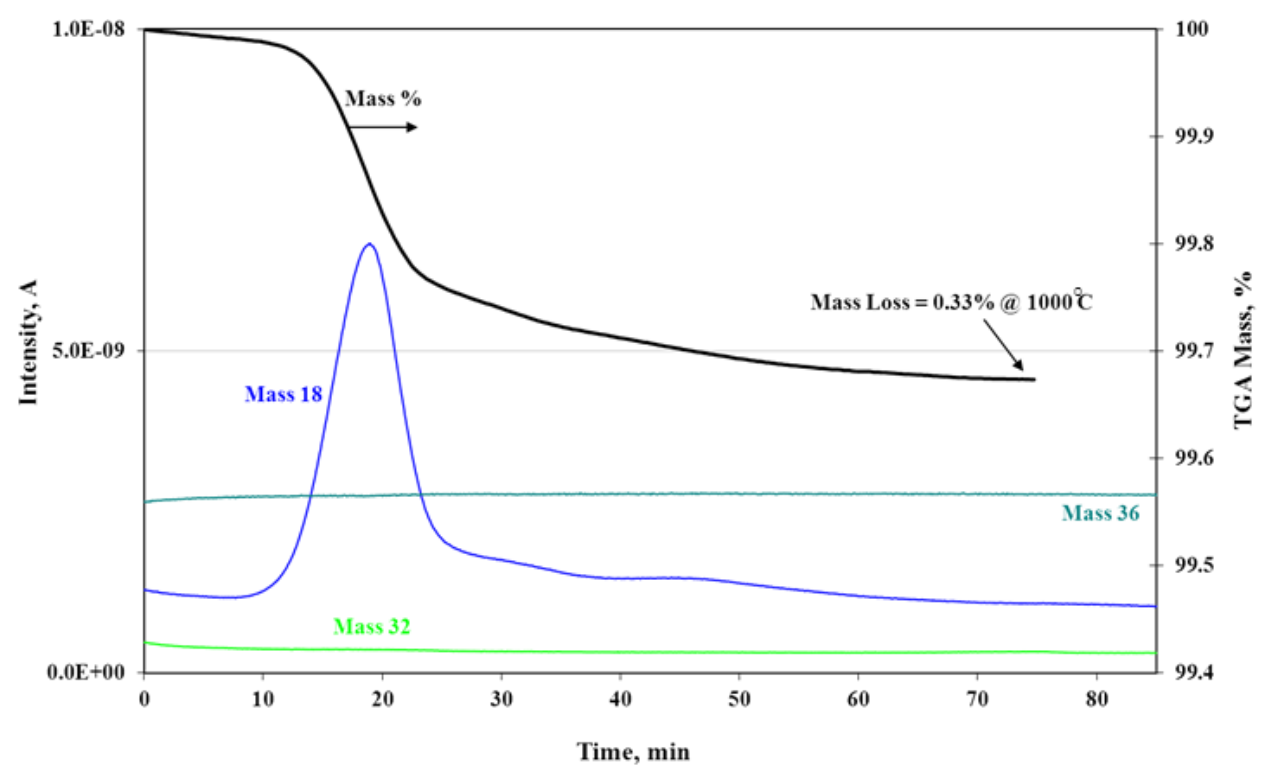

Figure 3-8. MS Signals (linear scale) from TGA-MS Analysis of Demo 1a Sample 
SRNL-STI-2012-00422

Revision 0

TGA-MS: FY2012 AFS2 (Demo 1 B402)

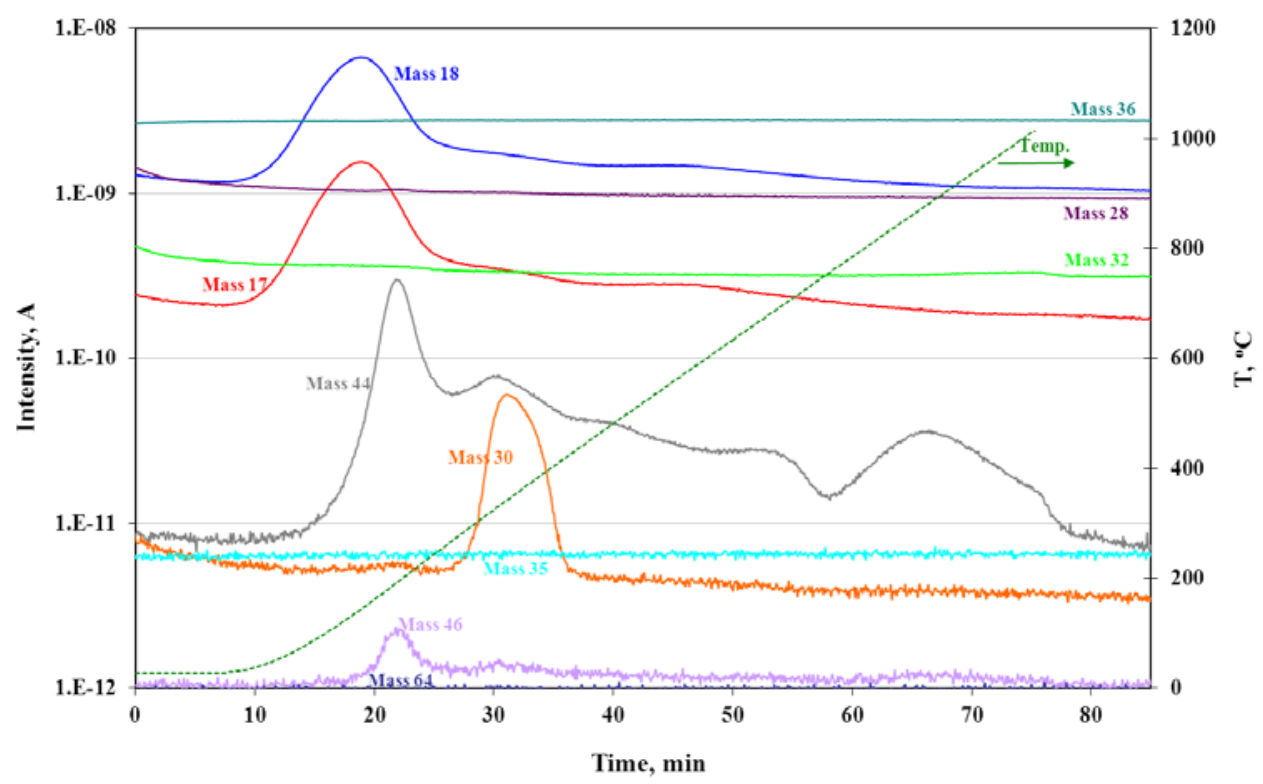

Figure 3-9. MS Signals (logarithmic scale) from TGA-MS Analysis of Demo 1a Sample

As shown in the figures, heating to $400{ }^{\circ} \mathrm{C}$ caused release of nearly all of the moisture from both samples Demo 1a and 1b. In addition, the largest portion of the carbon release, measured as Mass 44 or $\mathrm{CO}_{2}$, occurred in the same $\sim 40-300{ }^{\circ} \mathrm{C}$ temperature range as the bulk of the moisture release (Figure 3-8 and Figure 3-9). With carbon dioxide, however, its release continued through heating, with a second, smaller release centered at $\sim 850{ }^{\circ} \mathrm{C}$. A release of Mass 30, attributed to NO, occurred in the $300-500{ }^{\circ} \mathrm{C}$ range. The TGA-MS showed no other significant gas releases, including no Mass 28 (attributed to CO). Approximately 90\% of the total mass loss for each sample was associated with water loss. Quantitative TGA-MS results are shown in Table 3-7. .

Table 3-7. TGA-MS Results for Integrated Demonstration “Demo 1" Sample

\begin{tabular}{||l|c|c||}
\hline \multicolumn{1}{|c|}{ Sample } & $\begin{array}{c}\text { Total TGA } \\
\text { mass loss } \\
\text { wt \% }\end{array}$ & MS Moisture \\
wt \%
\end{tabular}

\footnotetext{
${ }^{\dagger}$ TGA test ended at $\sim 240{ }^{\circ} \mathrm{C}$.
} 
After exposing the Demo 1 sample to humid air at 44-60\% RH for four days, analyses began on portions of the exposed sample. Unfortunately, during analysis of the first exposed sample portion, Demo 1c, the TGA sample thermocouple failed. Based on the standard temperature profile and time, the TGA heated the sample to only $240{ }^{\circ} \mathrm{C}$. The results for Demo 1c are shown in Figure 3-10. Comparing these Demo 1c results to those of Demo 1a and 1b indicates that the $0.42 \mathrm{wt} \%$ moisture observed for the Demo 1c sample amounted to approximately $70 \%$ of the moisture in sample Demo 1c. Extrapolating the data, the extended, non-prototypical exposure to humid air likely caused the Demo 1 material to reach $\sim 0.6 \mathrm{wt} \%$, which exceeds the acceptable moisture limit of $0.50 \mathrm{wt} \%$. Small amounts of $\mathrm{CO}_{2}$ were also observed, but its mass was negligible compared to that of water.

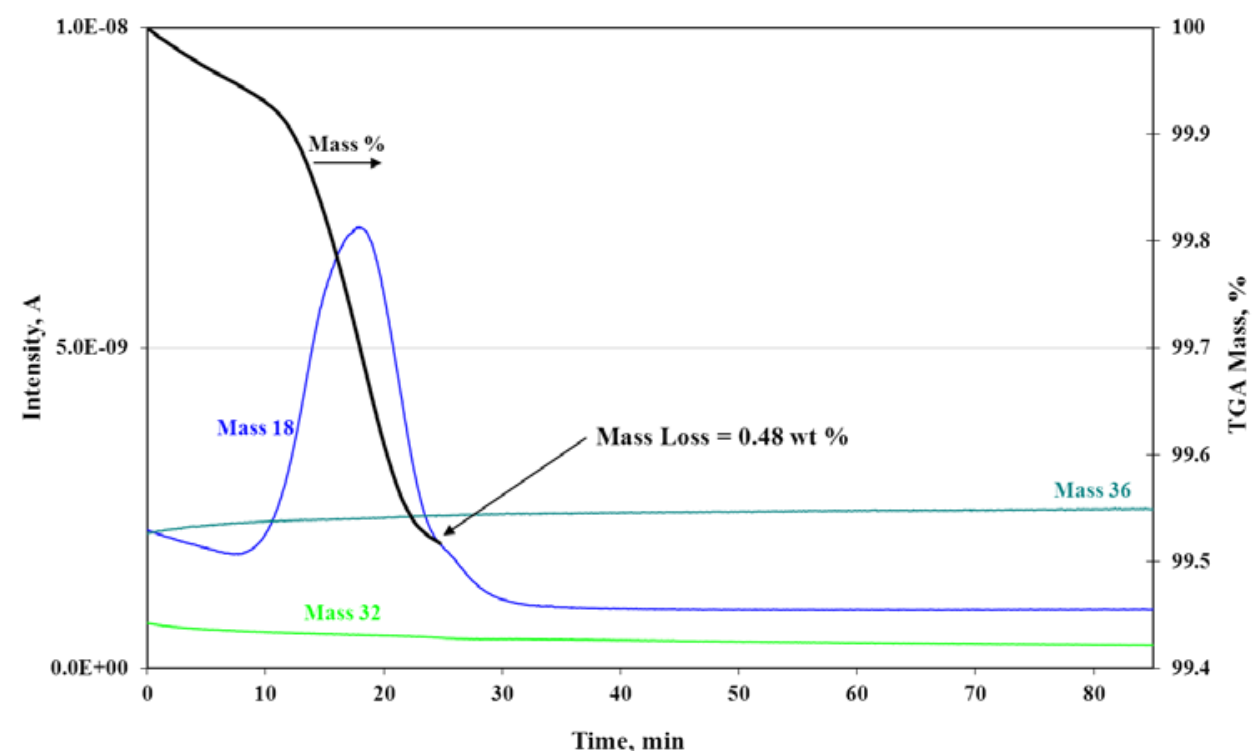

Figure 3-10. TGA-MS for Demo 1c Sample

To gauge the effectiveness of an inert purge gas for drying the moist Demo 1 material, sample portions were placed inside the argon purge stream of the TGA. One portion was kept at room temperature for $1 \mathrm{~h}$, while the other two portions were heated to either $\sim 50{ }^{\circ} \mathrm{C}$ or $\sim 93^{\circ} \mathrm{C}$ and held at temperature for $1 \mathrm{~h}$. For the sample kept at room temperature in flowing argon, the sample lost $0.30 \mathrm{wt} \%$, as shown in Figure 3-11, and likely would have continued to lose mass with additional time. 


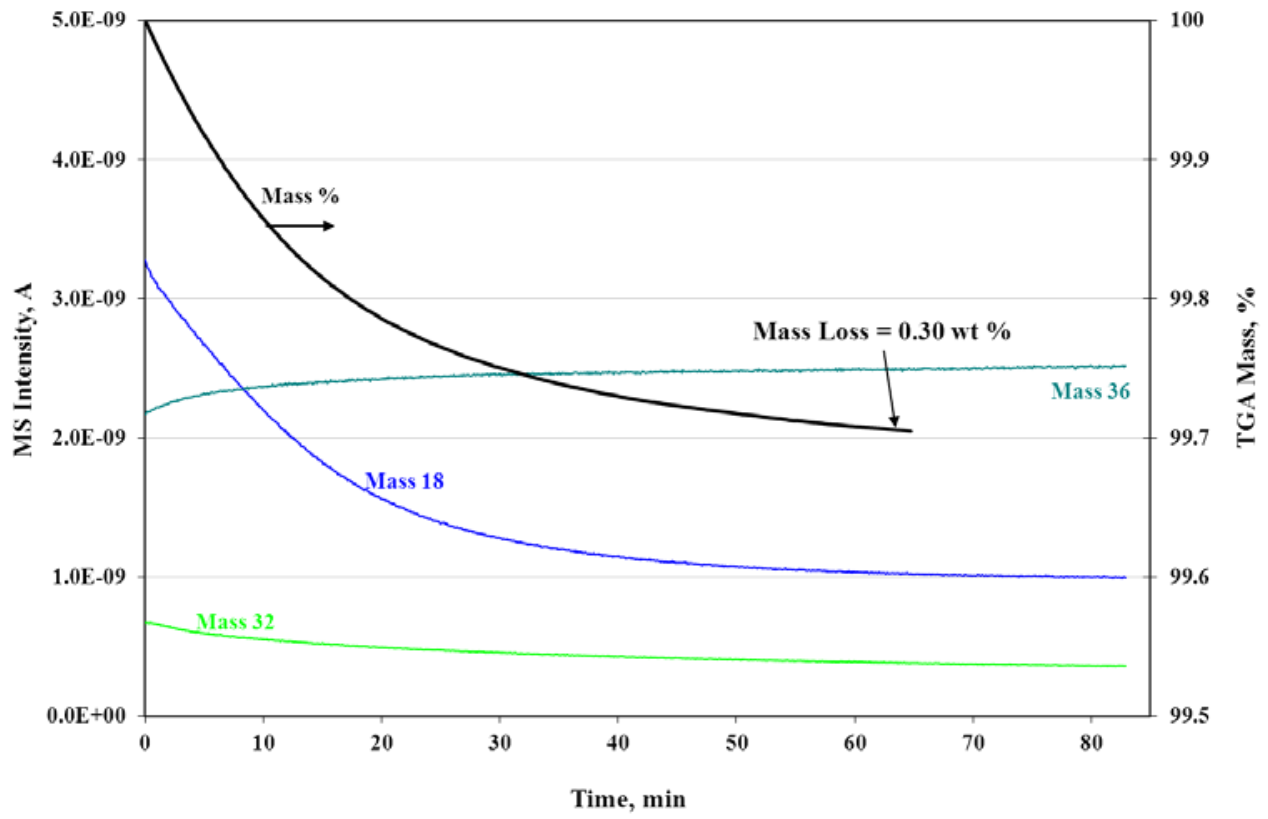

Figure 3-11. TGA-MS for Demo 1 Sample in Dry Argon at Room Temperature for $1 \mathrm{~h}$.

Similarly, as shown in Figure 3-12 and Figure 3-13, the Demo 1 sample portions heated to 50 and $93{ }^{\circ} \mathrm{C}$ lost a significant amount of moisture in the first 30 minutes and continued to lose moisture at a slower rate thereafter. The TGA mass losses of 0.36 and $0.45 \mathrm{wt} \%$ were essentially all due to moisture, based on the measured MS moisture contents of 0.37 and $0.44 \mathrm{wt} \%$, respectively, for the Demo 1 samples at 50 and $93{ }^{\circ} \mathrm{C}$. Assuming an estimated starting moisture content of $\sim 0.6 \mathrm{wt} \%$, the use of dry argon would be sufficient to achieve the required moisture content of $<0.50$ wt \%. These results suggest that future work is warranted if a need exists to dry similar $\mathrm{PuO}_{2}$ materials using an inert gas.

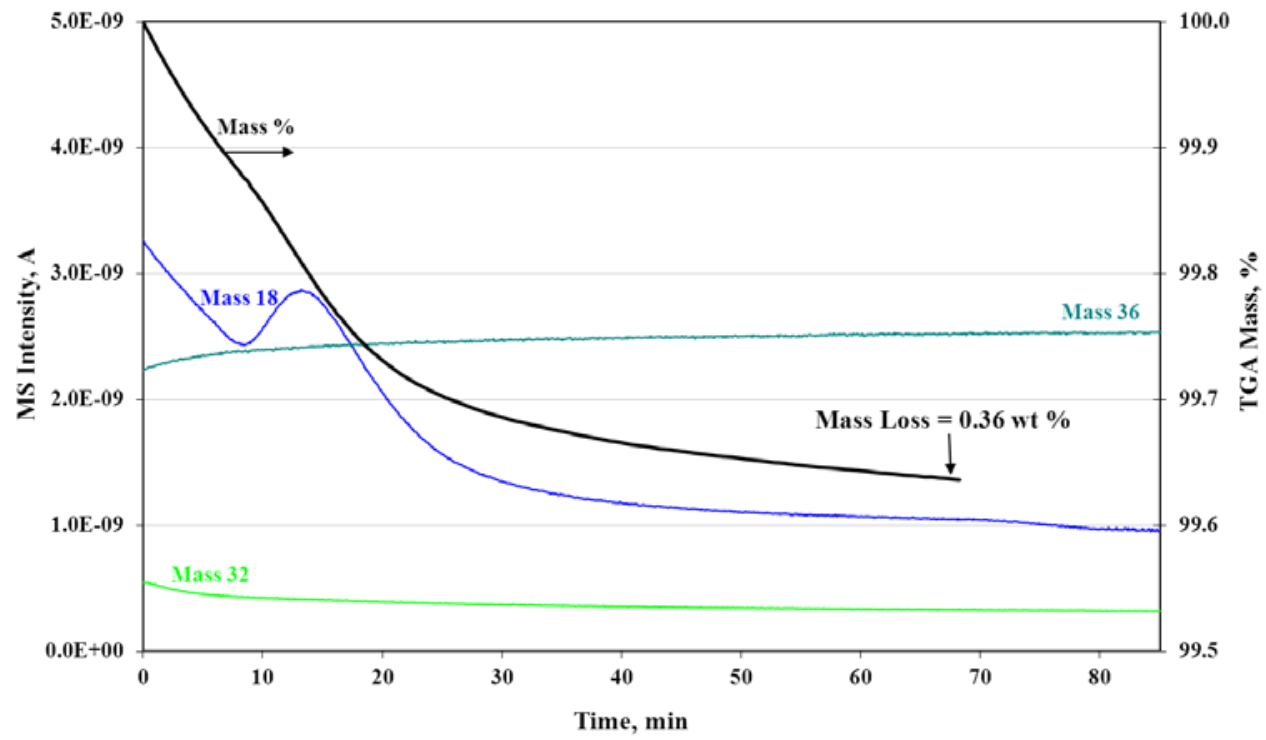

Figure 3-12. TGA-MS for Demo 1 Sample in Dry Argon at $\sim 50{ }^{\circ} \mathrm{C}$ for $1 \mathrm{~h}$. 


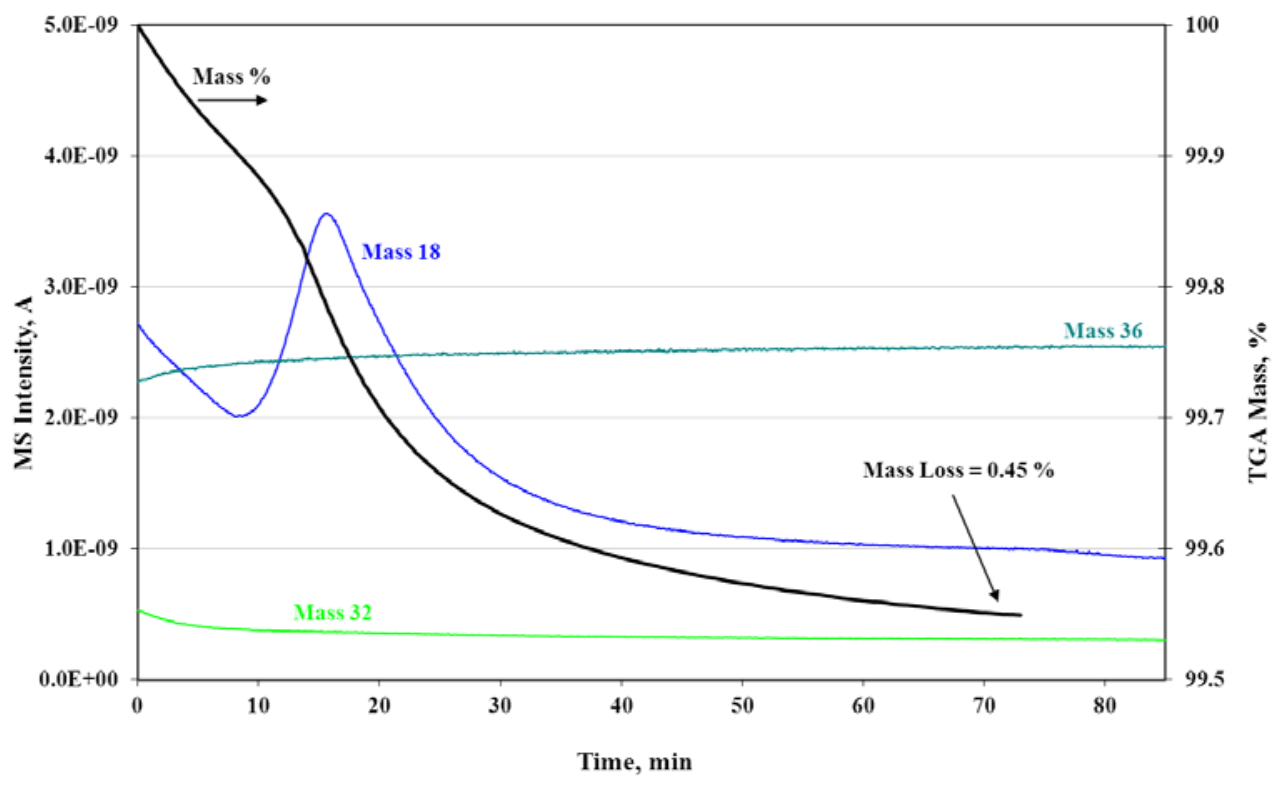

Figure 3-13. TGA-MS for Demo 1 Sample in Dry Argon at $\sim 93^{\circ} \mathrm{C}$ for $1 \mathrm{~h}$.

\subsubsection{Specific Surface Area}

The SSA for samples from the two demonstration batches are shown in Table 3-8.

Table 3-8. Specific Surface Area Measurements and Uncertainties

\begin{tabular}{|c|c|c|c||}
\hline \multirow{2}{*}{ Sample } & \multirow{2}{*}{$\begin{array}{l}\text { SSA } \\
\mathbf{m}^{2} / \mathbf{g}\end{array}$} & \multicolumn{2}{|c|}{ 95\% Confidence Interval } \\
\cline { 3 - 4 } & 9.63 & Lower Bound & Upper Bound \\
\hline Demo 1 & 9.45 & 9.80 \\
\hline Demo 2 & 9.22 & 9.14 & 9.30 \\
\hline
\end{tabular}

Generally, SSA samples are analyzed in duplicate and the average is reported. The expected SSA range ${ }^{9}$ for calcination at $650{ }^{\circ} \mathrm{C}$ is $5-14 \mathrm{~m}^{2} / \mathrm{g}$. The confidence interval for a specific sample depends in part on the precision of the duplicate portions of that sample. For this study, the SSA $95 \%$ confidence intervals correspond to uncertainties ranging from $\pm 0.87 \%$ to $\pm 1.87 \%$.

\subsubsection{Carbon and Sulfur Analysis}

Results for carbon and sulfur content for the samples analyzed are shown in Table 3-9. Future plans include comparing carbon analysis by TGA-MS to these values measured by a carbon analyzer. The values in Table 3-9 show that the carbon content of $\mathrm{PuO}_{2}$ produced at SRNL easily met the Column A limit of $1000 \mu \mathrm{g} \mathrm{C/g} \mathrm{Pu} \mathrm{and} \mathrm{the} \mathrm{Column} \mathrm{B} \mathrm{limit} \mathrm{of} 500 \mu \mathrm{g} \mathrm{C/g} \mathrm{Pu.} \mathrm{For} \mathrm{these}$ samples, carbon analyses were performed in triplicate, and the standard deviation of the replicates was less than $20 \%$. The sulfur content of $\mathrm{PuO}_{2}$ produced at SRNL also easily met the Column A and B limits of $250 \mu \mathrm{g} \mathrm{S} / \mathrm{g} \mathrm{Pu}$. 
SRNL-STI-2012-00422

Revision 0

Table 3-9. Carbon and Sulfur Contents of $\mathrm{PuO}_{2}$ Samples

\begin{tabular}{|c|c|c|c|c|}
\hline Batch & $\begin{array}{c}\mathrm{C} \\
\mathrm{wt} \%\end{array}$ & $\begin{array}{c}\mathrm{C} \\
\mu \mathrm{g} / \mathrm{g} \text { sample }\end{array}$ & $\begin{array}{c}\mathrm{C} \\
\mu \mathrm{g} / \mathrm{g} \mathrm{Pu}^{\dagger}\end{array}$ & Uncertainty \\
\hline Demo 1 & 0.025 & 250 & 290 & $\pm 20 \%$ \\
\hline \multirow[t]{2}{*}{ Demo 2} & 0.021 & 240 & 280 & $\pm 20 \%$ \\
\hline & $\begin{array}{c}\mathrm{S} \\
\text { wt } \%\end{array}$ & $\begin{array}{c}\mathrm{S} \\
\mu \mathrm{g} / \mathrm{g} \text { sample }\end{array}$ & $\begin{array}{c}\mathrm{S} \\
\mu \mathrm{g} / \mathrm{g} \mathrm{Pu}^{\dagger}\end{array}$ & Uncertainty \\
\hline Demo 1 & $<4 \mathrm{E}-6$ & $<0.040$ & $<0.046$ & $\pm 10 \%$ \\
\hline Demo 2 & $<4 \mathrm{E}-6$ & $<0.040$ & $<0.046$ & $\pm 10 \%$ \\
\hline
\end{tabular}

\subsubsection{Particle Size Analysis}

Personnel performed PSA on both $\mathrm{PuO}_{2}$ and Pu oxalate samples. The MOX specification ${ }^{10}$ states that the maximum particle size shall be $200 \mu \mathrm{m}$ with as few sub-5- $\mu \mathrm{m}$ as practical. The test results are summarized in Table 3-10, and the plots of particle size distribution are provided in the Appendix (Figures A-3 through A-6). The data in Table 3-10 indicate that the products meet the specification.

Table 3-10. Particle Size Analyses of Pu Oxalate and $\mathrm{PuO}_{2}$ Samples

\begin{tabular}{|c|c|c|c||}
\hline $\begin{array}{c}\text { Sample } \\
\text { ID }\end{array}$ & $\begin{array}{c}\text { Particle Size } \\
\text { Range } \\
\boldsymbol{\mu m}\end{array}$ & $\begin{array}{c}\text { Mean* } \\
\text { Particle Size } \\
\boldsymbol{\mu m}\end{array}$ & $\begin{array}{c}\text { Volume \% of } \\
\text { Particles } \\
<5.50 \mu m\end{array}$ \\
\hline Demo 1 $\mathrm{PuO}_{2}$ & $0.204-74.0$ & 12.2 & 14.0 \\
\hline Demo 2 $\mathrm{PuO}_{2}$ & $0.204-74.0$ & 11.8 & 13.9 \\
\hline Demo 1 Pu Oxalate & $0.344-124.5$ & 13.2 & 16.8 \\
\hline Demo 2 Pu Oxalate & $0.409-124.5$ & 17.1 & 10.3 \\
\hline
\end{tabular}

*Mean Particle Size determined on a volumetric basis.

\subsubsection{Density}

The bulk and tapped densities for the Demo 1 and 2 samples are shown in Table 3-11. For each measurement, the full sample was used. Hence, after the "Demo 1A" analysis, the full sample was poured back into the sample vial. The sample was then poured again into the graduated cylinder for a second ("Demo 1B") measurement of bulk and tapped densities. The bulk density is measured after the powder is poured into a graduated cylinder. The tapped density is measured after the graduated cylinder has been lightly tapped for five minutes.

The pycnometry density of both samples was also measured, as shown in Table 3-11. Pycnometry is a measure of the density of the material excluding the void space between particles. To measure pycnometry accurately, samples larger than the 7-13 g samples used in this study are recommended. Though the small sample sizes add some uncertainty to the pycnometry results, it is notable that the pycnometry densities agree with the published $\mathrm{PuO}_{2}$ density of $11.46 \mathrm{~g} / \mathrm{cm}^{3}{ }^{31}$ 
SRNL-STI-2012-00422

Revision 0

Table 3-11. Density Measurements

\begin{tabular}{||c|c|c|c||}
\hline & Bulk Density & $\begin{array}{c}\text { Powder Tap } \\
\text { Density } \\
\mathbf{g} / \mathbf{c m}^{\mathbf{3}}\end{array}$ & $\begin{array}{c}\text { Material Density } \\
\text { by Pycnometry } \\
\mathbf{g} / \mathbf{c m}^{\mathbf{3}}\end{array}$ \\
\hline Demo 1A & 1.57 & 2.05 & \multirow{2}{*}{11.73} \\
\hline Demo 1B & 1.53 & 2.11 & \multirow{2}{*}{11.07} \\
\hline Demo 2A & 1.53 & 2.06 & \\
\hline Demo 2B & 1.56 & 2.07 & \\
\hline
\end{tabular}

\subsubsection{Analysis of Dissolved $\mathrm{PuO}_{2}$}

The gamma PHA results for the four dissolved $0.25 \mathrm{~g}$ portions of $\mathrm{PuO}_{2}$ (two portions from each Demo batch) showed dissolved Pu contents of nominally 8-9 g Pu/L. To compare the impurity contents of these samples to the Column A Limits ${ }^{2}$, the analysis results are color-coded in Table 3-12. Red indicates the limit was not attained. For all of the "red" analytes except Gd (K, $\mathrm{Mo}, \mathrm{P}$, and $\mathrm{Si}$ ), the solutions showed less than the detection limit, but the limits were above the Column A specification. It should be noted that $\mathrm{C}$ and $\mathrm{S}$ were measured using the carbon-sulfur analyzer discussed in Section 3.3.3; ${ }^{241} \mathrm{Am}$ was determined by gamma analysis. All other results in Table 3-12 were determined by ICP-ES or ICP-MS, as indicated.

For analytes in which the Column A limit was attained, the closeness to the limit is indicated, in order, by the colors yellow, white, and green. Yellow indicates an impurity concentration between $50 \%$ and $100 \%$ of specification. White indicates an impurity concentration between $10 \%$ and $50 \%$ of specification. Green indicates an impurity concentration below $10 \%$ of specification. Elements measured by ICP-MS have been corrected assuming naturally-occurring isotopic abundance. 
Table 3-12. Impurity Contents of Dissolved $\mathrm{PuO}_{2}$ Solution

\begin{tabular}{|c|c|c|c|c|c|}
\hline Element & $\begin{array}{l}\text { Isotope } \\
\text { Used by } \\
\text { ICP-MS }\end{array}$ & $\begin{array}{c}\text { Column A } \\
\text { Limit } \\
\mu \mathrm{g} / \mathrm{g} \mathbf{P u}\end{array}$ & $\begin{array}{l}\text { Demo } 1 \\
\mu \mathrm{g} / \mathrm{g} \text { Pu }\end{array}$ & $\begin{array}{l}\text { Demo } 2 \\
\mu \mathrm{g} / \mathrm{g} \text { Pu }\end{array}$ & $\begin{array}{l}\text { \% of Column A } \\
\text { Limit (Average) }\end{array}$ \\
\hline $\mathrm{Ag}$ & -- & 250 & $<134.3$ & $<141.8$ & $<55.2$ \\
\hline $\mathrm{Al}$ & -- & 500 & 165.1 & $<79.2$ & 24.4 \\
\hline${ }^{241} \mathrm{Am}$ (gamma) & -- & 7000 & 24.1 & 27.0 & 0.4 \\
\hline $\mathrm{B}$ & -- & 100 & $<71.4$ & $<75.4$ & $<73.4$ \\
\hline $\mathrm{Be}$ & -- & 100 & $<1.0$ & $<1.1$ & $<1.0$ \\
\hline C (LECO) & -- & 1000 & 290 & 280 & 28.5 \\
\hline $\mathrm{Ca}$ & -- & 500 & 207.5 & 27.7 & 23.5 \\
\hline Cd (ICP-MS) & ${ }^{111} \mathrm{Cd}$ & 10 & $<0.44$ & $<0.46$ & $<4.6$ \\
\hline Cd (ICP-MS) & ${ }^{113} \mathrm{Cd}$ & 10 & $<4.62$ & $<4.87$ & $<47.4$ \\
\hline Co & -- & 100 & $<22.9$ & $<24.2$ & $<23.5$ \\
\hline Co (ICP-MS) & ${ }^{59} \mathrm{Co}$ & 100 & $<0.34$ & $<0.36$ & $<0.35$ \\
\hline $\mathrm{Cr}$ & -- & 1000 & $<27.1$ & $<28.6$ & $<2.8$ \\
\hline $\mathrm{Cu}$ & -- & 100 & $<23.4$ & $<24.7$ & $<24.0$ \\
\hline Dy (ICP-MS) & ${ }^{163} \mathrm{Dy}$ & 1 & 1.25 & 0.46 & 85.2 \\
\hline Eu (ICP-MS) & ${ }^{151} \mathrm{Eu}$ & 1 & $<0.15$ & $<0.16$ & $<15.2$ \\
\hline Eu (ICP-MS) & ${ }^{153} \mathrm{Eu}$ & 1 & 0.16 & $<0.14$ & $<15.3$ \\
\hline $\mathrm{Fe}$ & -- & 2000 & $<144.5$ & $<86.3$ & 5.8 \\
\hline $\mathrm{Ga}$ & -- & 12000 & $<24.0$ & $<25.4$ & $<0.2$ \\
\hline Ga (ICP-MS) & ${ }^{69} \mathrm{Ga}$ & 12000 & $<0.75$ & $<0.79$ & $<0.006$ \\
\hline Ga (ICP-MS) & ${ }^{71} \mathrm{Ga}$ & 12000 & $<0.21$ & $<0.22$ & $<0.002$ \\
\hline Gd (ICP-MS) & ${ }^{155} \mathrm{Gd}$ & 3 & 4.25 & 1.79 & 101 \\
\hline Gd (ICP-MS) & ${ }^{157} \mathrm{Gd}$ & 3 & 4.94 & 1.83 & 113 \\
\hline $\mathrm{K}$ & -- & 300 & $<426.5$ & $<450.5$ & $<146.2$ \\
\hline $\mathrm{Li}$ & -- & 400 & $<21.6$ & $<22.8$ & $<5.5$ \\
\hline $\mathrm{Mg}$ & -- & 500 & $<12.4$ & $<13.1$ & $<2.6$ \\
\hline $\mathrm{Mn}$ & -- & 100 & $<4.3$ & $<4.5$ & $<4.4$ \\
\hline Mo & -- & 100 & $<139.9$ & $<147.8$ & $<143.8$ \\
\hline $\mathrm{Na}$ & -- & 1000 & 197.2 & 101.5 & 14.9 \\
\hline $\mathrm{Ni}$ & -- & 5000 & $<46.4$ & $<49.0$ & $<1.0$ \\
\hline $\mathrm{P}$ & -- & 200 & $<515.7$ & $<544.6$ & $<265.1$ \\
\hline $\mathrm{Pb}$ (ICP-MS) & ${ }^{206} \mathrm{~Pb}$ & 200 & $<23.4$ & $<24.7$ & $<12.0$ \\
\hline $\mathrm{Pb}$ (ICP-MS) & ${ }^{207} \mathrm{~Pb}$ & 200 & $<25.5$ & $<26.9$ & $<13.1$ \\
\hline $\mathrm{Pb}$ (ICP-MS) & ${ }^{208} \mathrm{~Pb}$ & 200 & $<21.5$ & $<22.7$ & $<11.1$ \\
\hline S (LECO) & -- & 250 & $<0.046$ & $<0.046$ & $<0.02$ \\
\hline $\mathrm{Si}$ & -- & 200 & $<2408.7$ & $<1661.8$ & $<1017.6$ \\
\hline Sm (ICP-MS) & ${ }^{147} \mathrm{Sm}$ & 2 & 0.93 & $<0.50$ & $<35.8$ \\
\hline Sm (ICP-MS) & ${ }^{149} \mathrm{Sm}$ & 2 & 0.72 & $<0.54$ & $<31.5$ \\
\hline Sn (ICP-MS) & ${ }^{118} \mathrm{Sn}$ & 100 & $<18.6$ & $<19.6$ & $<19.1$ \\
\hline Sn (ICP-MS) & ${ }^{120} \mathrm{Sn}$ & 100 & $<17.4$ & $<18.4$ & $<17.9$ \\
\hline Ta (ICP-MS) & ${ }^{181} \mathrm{Ta}$ & 200 & 13.3 & 15.4 & 7.2 \\
\hline Th (ICP-MS) & ${ }^{232} \mathrm{Th}$ & 100 & $<6.2$ & $<6.6$ & $<6.4$ \\
\hline $\mathrm{Ti}$ & -- & 100 & 8.1 & $<5.3$ & 6.7 \\
\hline $\mathrm{U}$ & -- & 5000 & $<732.3$ & $<773.4$ & $<15.1$ \\
\hline $\mathrm{V}$ & -- & 300 & $<6.5$ & $<6.9$ & $\overline{<2.2}$ \\
\hline W (ICP-MS) & ${ }^{182} \mathrm{~W}$ & 200 & $<15.0$ & $<15.9$ & $<7.7$ \\
\hline $\mathrm{Zn}$ & -- & 150 & 20.9 & $<17.4$ & 12.8 \\
\hline $\mathrm{Zr}$ & -- & 50 & $<7.0$ & $<7.4$ & $<14.4$ \\
\hline
\end{tabular}


For comparison, data for the starting hearts-cut solution are provided in Table 3-13. All results were determined by ICP-ES or ICP-MS, as indicated, after removal of Pu.

Table 3-13. Impurity Contents of Starting Hearts-Cut Pu Solution

\begin{tabular}{|c|c|c|c|c|c|}
\hline \multirow[t]{2}{*}{ Element } & \multirow[t]{2}{*}{$\begin{array}{l}\text { Isotope } \\
\text { Used by } \\
\text { ICP-MS }\end{array}$} & $\begin{array}{l}\text { Column } \\
\text { A Limit }\end{array}$ & Sample & Sample & \multirow{2}{*}{$\begin{array}{c}\text { \% of } \\
\text { Column A } \\
\text { Limit } \\
\text { (Average) }\end{array}$} \\
\hline & & $\mu \mathrm{g} / \mathrm{g} \mathrm{Pu}$ & $\mathrm{mg} / \mathrm{L}$ & $\mu \mathrm{g} / \mathrm{g} \mathrm{Pu}$ & \\
\hline $\mathrm{Ag}$ & -- & 250 & $<5.35$ & $<119.4$ & $<47.8$ \\
\hline $\mathrm{Al}$ & -- & 500 & $<3$ & $<67.0$ & $<13.4$ \\
\hline $\mathrm{B}$ & -- & 100 & $<2.85$ & $<63.6$ & $<63.6$ \\
\hline $\mathrm{Be}$ & -- & 100 & $<0.04$ & $<0.9$ & $<0.9$ \\
\hline $\mathrm{Ca}$ & -- & 500 & $<7.97$ & $<177.9$ & $<35.6$ \\
\hline Cd (ICP-MS) & ${ }^{113} \mathrm{Cd}$ & 10 & $<0.0095$ & $<1.74$ & $<17.4$ \\
\hline Co & -- & 100 & $<0.915$ & $<20.4$ & $<20.4$ \\
\hline Co (ICP-MS) & ${ }^{59} \mathrm{Co}$ & 100 & $<0.00062$ & $<0.014$ & $<0.01$ \\
\hline $\mathrm{Cr}$ & -- & 1000 & $<0.54$ & $<12.1$ & $<1.2$ \\
\hline $\mathrm{Cu}$ & -- & 100 & $<0.93$ & $<20.8$ & $<20.8$ \\
\hline Dy (ICP-MS) & ${ }^{163} \mathrm{Dy}$ & 1 & $<0.00062$ & $<0.056$ & $<5.6$ \\
\hline Eu (ICP-MS) & ${ }^{153} \mathrm{Eu}$ & 1 & $<0.00062$ & $<0.0265$ & $<2.7$ \\
\hline $\mathrm{Fe}$ & -- & 2000 & 4.78 & 106.7 & 5.3 \\
\hline Ga (ICP-MS) & ${ }^{69} \mathrm{Ga}$ & 12000 & 0.0066 & 0.245 & 0.002 \\
\hline Gd (ICP-MS) & ${ }^{155} \mathrm{Gd}$ & 3 & 0.0058 & 0.875 & 29.2 \\
\hline Gd (ICP-MS) & ${ }^{157} \mathrm{Gd}$ & 3 & 0.0076 & 1.09 & 36.2 \\
\hline $\mathrm{K}$ & -- & 300 & $<38.2$ & $<852.7$ & $<284$ \\
\hline $\mathrm{Li}$ & -- & 400 & $<0.86$ & $<19.2$ & $<4.8$ \\
\hline $\mathrm{Mg}$ & -- & 500 & $<9.4$ & $<209.8$ & $<42.0$ \\
\hline $\mathrm{Mn}$ & -- & 100 & $<0.17$ & $<3.79$ & $<3.8$ \\
\hline Mo & -- & 100 & $<5.58$ & $<124.6$ & $<125$ \\
\hline $\mathrm{Na}$ & -- & 1000 & $<25.5$ & $<569.2$ & $<56.9$ \\
\hline $\mathrm{Ni}$ & -- & 5000 & $<1.85$ & $<41.3$ & $<0.8$ \\
\hline $\mathrm{P}$ & -- & 200 & $<27.3$ & $<609.4$ & $<305$ \\
\hline $\mathrm{Pb}$ (ICP-MS) & ${ }^{206} \mathrm{~Pb}$ & 200 & $<0.031$ & $<2.87$ & $<1.4$ \\
\hline $\mathrm{Pb}$ (ICP-MS) & ${ }^{207} \mathrm{~Pb}$ & 200 & $<0.031$ & $<3.13$ & $<1.6$ \\
\hline $\mathrm{Si}$ & -- & 200 & $<10.8$ & $<241.1$ & $<121$ \\
\hline Sm (ICP-MS) & ${ }^{147} \mathrm{Sm}$ & 2 & $<0.00062$ & $<0.092$ & $<4.6$ \\
\hline Sm (ICP-MS) & ${ }^{149} \mathrm{Sm}$ & 2 & $<0.00062$ & $<0.100$ & $<5.0$ \\
\hline Sn (ICP-MS) & ${ }^{118} \mathrm{Sn}$ & 100 & 0.0087 & 0.799 & 0.8 \\
\hline Sn (ICP-MS) & ${ }^{120} \mathrm{Sn}$ & 100 & 0.031 & 2.14 & 2.1 \\
\hline $\mathrm{Ti}$ & -- & 100 & $<0.2$ & $<4.46$ & $<4.5$ \\
\hline $\mathrm{U}$ & -- & 5000 & $<29.2$ & $<651.8$ & $<13.0$ \\
\hline $\mathrm{V}$ & -- & 300 & $<0.26$ & $<5.80$ & $<1.9$ \\
\hline $\mathrm{Zn}$ & -- & 150 & $<0.655$ & $<14.6$ & 9.7 \\
\hline $\mathrm{Zr}$ & -- & 50 & $<0.28$ & $<6.25$ & $<12.5$ \\
\hline
\end{tabular}


In Table 3-12 there are five elements that may exceed the Column A limit -Gd, K, Mo, P, and Si. Of these, four of the analyte (K, Mo, $\mathrm{P}$, and $\mathrm{Si}$ ) measurements are below the method detection limit. Therefore, only Gd was positively detected above the Column A limit. Of the five elements that exceed the Column A limit in Table 3-12, four of them are also above the limit in Table 3-13. However, in all four cases, the concentrations in Table 3-13 are below the measurement detection limit.

Table 3-13 shows that Gd was at $~ 30 \%$ of the Column A limit in the feed prior to precipitation, compared to $153 \%$ and $60 \%$ for the first and second batches, respectively, after calcination. The source of the additional impurity is not clear. However, in this study the filtrate solutions were recycled and used to rinse the precipitate out of the beaker. This method differed from the method used in the smaller-scale study completed recently on the same equipment. It is likely that the filtrate collection beakers were not thoroughly cleaned and rinsed, and that recycling of the filtrate, therefore, introduced contamination into the $\mathrm{Pu}$ oxalate, which was retained during calcination. Analyses of nitric and oxalic acids used in this study did not show detectable Gd. However, the challenging specifications for several elements make it important to ensure that feed chemicals used by HB-Line are sufficiently pure. For the reagent grade nitric and oxalic acids used in this study, analytical results are provided in the Appendix, and show that the reagents used in this study did not contribute significant impurities to the Pu solution and the $\mathrm{PuO}_{2}$ powder produced.

Of the four elements that exceed the Column A limit in both tables, none of them are expected to be retained by the anion exchange column, nor are they expected to precipitate with oxalic acid. Kyser and King previously reported on the behavior of K, Mo, P, and Si in anion exchange and their expected level in the feed materials. ${ }^{3}$ Consequently, based on process knowledge and the absence of data positively confirming that $\mathrm{K}, \mathrm{Mo}, \mathrm{P}$, and $\mathrm{Si}$ are above the Column A limit, it is expected that they are below the limit. Additional method development is needed to provide verification that the purity levels can be achieved for those elements.

\subsection{Conclusions}

An anion exchange column experiment produced $1.76 \mathrm{~L}$ of a purified $44.8 \mathrm{~g} / \mathrm{L} \mathrm{Pu}$ solution at $1.23 \mathrm{M}$ free acid. After increasing the acidity to $1.54 \mathrm{M}$, researchers performed two batches of $\mathrm{Pu}(\mathrm{IV})$ oxalate precipitation at $50{ }^{\circ} \mathrm{C}$ using precipitation times expected in HB-Line. The resulting two batches of Pu oxalate were calcined separately at $650{ }^{\circ} \mathrm{C}$ for nominally four hours, with a flow of air passing through the furnace.

Replicate samples of $\mathrm{PuO}_{2}$ from the Demo 1 batch, which had limited exposure to humid air, showed TGA mass losses of $0.33-0.34$ wt \% when heated to $1000{ }^{\circ} \mathrm{C}$. Mass spectrometry evaluation of these samples indicated moisture contents of $0.30-0.32 \mathrm{wt} \%$. Exposing additional sample Demo 1 material to humid air ( $44-60 \%$ RH) for four days yielded material that likely contained $>0.50$ wt \% moisture, but an instrument problem prevented heating of that sample above $\sim 250^{\circ} \mathrm{C}$.

Subsequent studies with Demo 1 sample portions exposed to humid air showed that placing the $\mathrm{PuO}_{2}$ in a stream of dry argon gas for 1 hour caused release of significant amounts of moisture, with a moisture loss of $0.26 \mathrm{wt} \%$ at room temperature, increasing to a moisture loss of $0.44 \mathrm{wt} \%$ at $\sim 93{ }^{\circ} \mathrm{C}$. Assuming an estimated starting moisture content of $\sim 0.6 \mathrm{wt} \%$, the use of dry argon would be sufficient to achieve the required moisture content of $<0.50 \mathrm{wt} \%$. 
TGA-MS data for the Demo 1 sample was consistent with an earlier study of small-scale samples produced via similar conditions, where the bulk of the moisture was released from samples by $300{ }^{\circ} \mathrm{C}$, along with a significant portion of the $\mathrm{CO}_{2}$. As with earlier samples, the Demo 1 material released a minor amount of $\mathrm{NO}$ in the $\sim 40-300{ }^{\circ} \mathrm{C}$ range, but did not release $\mathrm{CO}$ or $\mathrm{SO}_{2}$.

Both batches of $\mathrm{PuO}_{2}$ produced in this study exhibited good purity. In the oxide product there were five elements that may exceed the Column A limit for MOX oxide feed - Gd, K, Mo, P, and $\mathrm{Si}$. Of these, four of the analyte (K, Mo, P, and $\mathrm{Si}$ ) measurements were below the method detection limit. Therefore, only Gd was positively detected above the Column A limit. Of the five elements that exceeded the limit in the oxide product, four of them (K, Mo, P, and $\mathrm{Si})$ are also above the limit in the Pu feed solution to precipitation. However, in all four cases, the concentrations in the Pu feed solution were also below the measurement detection limit.

The analyses show that Gd was at $~ 30 \%$ of the limit in the feed solution prior to precipitation, compared to 150 and $60 \%$ for the first and second batches of $\mathrm{PuO}_{2}$, respectively, after calcination. The additional impurity may have resulted from using filtration equipment that was not thoroughly cleaned and recycling the filtrate to rinse precipitate out of the beaker. This potential cause is consistent with the first batch containing more Gd than the second batch, as the equipment would have been rinsed somewhat during first batch operations.

Of the four elements $(\mathrm{K}, \mathrm{Mo}, \mathrm{P}$, and $\mathrm{Si}$ ) that exceed the oxide product limit while being below the method detection limits, none of them are expected to be retained by the anion exchange column, nor are they expected to precipitate with oxalic acid. Consequently, based on process knowledge and the absence of data positively confirming that $\mathrm{K}, \mathrm{Mo}, \mathrm{P}$, and Si were above the Column A limit, it is likely that they were below the limit. Additional method development should be performed to verify that the purity levels can be achieved for those elements.

The carbon content of the two calcination batches was 280-290 $\mu \mathrm{g} \mathrm{C/g} \mathrm{Pu,} \mathrm{which} \mathrm{meets} \mathrm{the}$ $1000 \mu \mathrm{g}$ C/g Pu specification. The $\mathrm{PuO}_{2}$ samples produced in both batches had particles sizes that ranged from $0.2-74.0 \mu \mathrm{m}$. These results meet the specification of $<200 \mu \mathrm{m}$. For the two batches, the volume percent of particles $<5.50 \mu \mathrm{m}$ was $13.9-14.0 \%$. The SSA of the $\mathrm{PuO}_{2}$ samples was $9.22-9.63 \mathrm{~m}^{2} / \mathrm{g}$. The expected SSA range was $5-14 \mathrm{~m}^{2} / \mathrm{g}$.

\subsection{Recommendations}

To determine the operating conditions needed to dry large $(\mathrm{kg})$ quantities of $\mathrm{PuO}_{2}$ using a dry gas purge, SRNL recommends further studies. Moisture absorption studies with $\mathrm{PuO}_{2}$ having surface areas in the region of interest, $5-14 \mathrm{~m}^{2} / \mathrm{g}$, are recommended at the 1-40 g scale. In addition, $\mathrm{kg}$ scale studies using cerium oxide $\left(\mathrm{CeO}_{2}\right)$ or a similar surrogate for $\mathrm{PuO}_{2}$ are recommended to understand the flow rates, times, and equipment dimensions needed to dry bulk quantities of $\mathrm{PuO}_{2}$.

To ensure sufficient purity of the $\mathrm{H}$ Area $\mathrm{PuO}_{2}$ product, particularly for Gd, which is used in $\mathrm{H}$ Area processes, SRNL recommends consideration of reducing the presence of Gd and other impurities in tank heels, process piping, and other potential sources of impurities. Similarly, SRNL recommends consideration of the purity of feed chemicals and process solutions to ensure sufficient $\mathrm{PuO}_{2}$ purity. 


\subsection{Future Work}

To reduce the detection limit for boron (B) analysis, method development work at $\mathrm{F} / \mathrm{H}$ Laboratory is planned. After method development progresses, the $\mathrm{PuO}_{2}$ samples generated in this study will be analyzed for B. In addition, work is planned to determine the decontamination factor (DF) for B due to the precipitation, filtration and calcination processes. The approach for determining B DF due to the precipitation, filtration and calcination processes will likely be similar to the work done to determine the DF for fluoride and chloride ions due to the precipitation, filtration and calcination processes. ${ }^{12}$ A sample of the $\mathrm{PuO}_{2}$ produced in this study has been delivered to F/H Laboratory for this future work. 
SRNL-STI-2012-00422

Revision 0

\subsection{References}

${ }^{1}$ Christopher, J.W., Task Technical Request, "Flow Sheet Verification for HB-Line Phase II Plutonium Oxide Production PPT/FLT/Calcination Operations and 3013 Equivalency”, NMMDHTS-2011-3178, November 22, 2011.

2 Crowder, M.L., and J.M. Duffey, “Task Technical and Quality Assurance Plan for Precipitation and Calcination of Plutonium(IV) Oxalate to Form Plutonium Oxide and Subsequent Gas Generation Studies to Support the MOX Feed Mission”, SRNL-RP-2011-01657, Rev. 0, Savannah River National Laboratory, January 15, 2011.

${ }^{3}$ Kyser, E.A., and W.D. King, "HB-Line Anion Exchange Purification of AFS-2 Plutonium for MOX”, SRNL-STI-2012-00233, Savannah River National Laboratory, April 2012.

${ }^{4}$ Crowder, M.L., R.A. Pierce, J.H. Scogin, W.E. Daniel, and W.D. King, "Small-scale Testing of Plutonium(IV) Oxalate Precipitation and Calcination to Plutonium Oxide to Support the MOX Feed Mission”, SRNL-STI-2012-00338, Savannah River National Laboratory, June 2012.

5 Smith, R.H., "HB-Line Pu-239 Production Flow Sheet Strategy (U)”, SRNS-E1100-201100025, October 12, 2011.

6 Jones, M.A., D.P. DiPrete, and B.J. Wiedenman, “Application of Column Extraction Method for Impurities Analysis on HB-Line Plutonium Oxide in Support of MOX Feed Product Specifications”, SRNL-STI-2012-00148, Rev. 0, Savannah River National Laboratory, March 2012.

7 Bronikowski, M.G., J.M. Duffey, and R.R. Livingston, "Lab Scale Production of $\mathrm{NpO}_{2}$ ”, WSRC-TR-2003-00392, Savannah River National Laboratory, August 2003.

${ }^{8}$ Duffey, J.M., B.C. Hill, and R.R. Livingston, "Capability for Moisture Removal from Neptunium Oxide by the HB-Line 9975 Inerting Process”, WSRC-TR-2004-00602, Savannah River National Laboratory, February 2005.

${ }^{9}$ Daniel, W.E., "Literature Review of $\mathrm{PuO}_{2}$ Calcination Time and Temperature Data for Specific Surface Area”, SRNL-TR-2011-00334, Savannah River National Laboratory, March 6, 2012.

${ }^{10}$ McAlhany, S. "Mixed Oxide Fuel Fabrication Facility (MFFF) - H-Area/K-Area Plutonium Oxide Powder Interface Control Document”, ICD-11-032-01, G-ESR-H-00189, Revision 0, National Nuclear Security Administration, May 31, 2012.

${ }^{11}$ Weast, R.C., M.J. Astle, and W.H. Beyer, CRC Handbook of Chemistry and Physics, $64^{\text {th }}$ Ed., CRC Press, Boca Raton, FL, 1984.

${ }^{12}$ Kyser, E.A., "Decontamination of Plutonium from Fluoride and Chloride during Oxalate Precipitation, Filtration and Calcination Processes”, SRNL-STI-2012-00433, Rev. 0, Savannah River National Laboratory, July 2012. 
SRNL-STI-2012-00422

Revision 0

Appendix A

A-1 
Table A-1. Sample Analyses by Gamma Spectroscopy and Pu TTA.

\begin{tabular}{|l|c|c|c|c|}
\hline \multicolumn{1}{|c|}{ Sample ID } & $\begin{array}{c}{ }^{239} \mathbf{P u} \\
\mathbf{( d p m} / \mathbf{m L} \mathbf{n}\end{array}$ & $\begin{array}{c}\text { WG Pu } \\
\mathbf{( g / L )}\end{array}$ & $\begin{array}{c}{ }^{241} \mathbf{A m} \\
\mathbf{( d p m} / \mathbf{m L} \mathbf{)}\end{array}$ & $\begin{array}{c}{ }^{241} \mathbf{A m} \\
\mathbf{( m g} / \mathbf{L})\end{array}$ \\
\hline Feed Item 1 & $9.30 \mathrm{E}+08$ & 7.17 & $1.21 \mathrm{E}+08$ & 15.86 \\
\hline Feed Item 4 & $5.87 \mathrm{E}+08$ & 4.53 & $8.43 \mathrm{E}+07$ & 11.05 \\
\hline Feed Eff 1 & $4.65 \mathrm{E}+04$ & 0.000 & $8.51 \mathrm{E}+05$ & 0.11 \\
\hline Feed Eff 2 & $8.05 \mathrm{E}+05$ & 0.006 & $6.10 \mathrm{E}+07$ & 7.99 \\
\hline Feed Eff 3 & $1.48 \mathrm{E}+06$ & 0.011 & $9.68 \mathrm{E}+07$ & 12.69 \\
\hline Feed Eff 4 & $1.56 \mathrm{E}+06$ & 0.012 & $8.87 \mathrm{E}+07$ & 11.63 \\
\hline Wash 1 & $<1.66 \mathrm{E}+06$ & $<0.013$ & $8.26 \mathrm{E}+07$ & 10.83 \\
\hline Wash 2 & $<1.10 \mathrm{E}+06$ & $<0.008$ & $3.62 \mathrm{E}+07$ & 4.74 \\
\hline Wash 3 & $<1.88 \mathrm{E}+06$ & $<0.014$ & $7.70 \mathrm{E}+06$ & 1.01 \\
\hline Wash 4 & $<1.53 \mathrm{E}+06$ & $<0.012$ & $2.65 \mathrm{E}+06$ & 0.35 \\
\hline Wash 5 & $<7.90 \mathrm{E}+05$ & $<0.006$ & $1.07 \mathrm{E}+06$ & 0.14 \\
\hline Wash 6 & $<1.12 \mathrm{E}+06$ & $<0.009$ & $6.89 \mathrm{E}+05$ & 0.09 \\
\hline Wash 7 & $2.94 \mathrm{E}+06$ & 0.023 & $4.99 \mathrm{E}+05$ & 0.07 \\
\hline Wash 8 & $4.90 \mathrm{E}+06$ & 0.038 & $3.65 \mathrm{E}+05$ & 0.05 \\
\hline Heads 0.3 & $1.64 \mathrm{E}+07$ & 0.126 & $2.68 \mathrm{E}+06$ & 0.35 \\
\hline Heads 0.4 & $1.94 \mathrm{E}+07$ & 0.150 & $2.37 \mathrm{E}+06$ & 0.31 \\
\hline Heads 0.5 & $1.65 \mathrm{E}+07$ & 0.127 & $2.16 \mathrm{E}+06$ & 0.28 \\
\hline Heads 0.6 & $2.74 \mathrm{E}+07$ & 0.211 & $3.28 \mathrm{E}+06$ & 0.43 \\
\hline Heads 0.7 & $4.96 \mathrm{E}+08$ & 3.82 & $5.71 \mathrm{E}+06$ & 0.75 \\
\hline Heads 0.8 & $6.42 \mathrm{E}+09$ & 49.5 & $1.19 \mathrm{E}+07$ & 1.56 \\
\hline Heads & $<5.91 \mathrm{E}+07$ & $<0.456$ & $2.60 \mathrm{E}+06$ & 0.34 \\
\hline Product & $5.81 \mathrm{E}+09$ & 44.9 & $5.50 \mathrm{E}+06$ & 0.72 \\
\hline Hearts 60 & $1.22 \mathrm{E}+09$ & 9.41 & $<2.27 \mathrm{E}+05$ & $<0.03$ \\
\hline Hearts 55 & $5.50 \mathrm{E}+08$ & 4.24 & $<1.82 \mathrm{E}+05$ & $<0.02$ \\
\hline Hearts 50 & $3.04 \mathrm{E}+08$ & 2.34 & $1.45 \mathrm{E}+05$ & 0.02 \\
\hline Hearts 45 & $1.32 \mathrm{E}+08$ & 1.02 & $5.70 \mathrm{E}+04$ & 0.01 \\
\hline Hearts 40 & $7.00 \mathrm{E}+07$ & 0.540 & $4.54 \mathrm{E}+04$ & 0.01 \\
\hline Hearts 35 & $3.75 \mathrm{E}+07$ & 0.289 & $2.96 \mathrm{E}+04$ & 0.00 \\
\hline Tails 1 & $1.49 \mathrm{E}+08$ & 1.15 & $4.85 \mathrm{E}+04$ & 0.01 \\
\hline Tails 2 & $7.51 \mathrm{E}+06$ & 0.058 & $1.21 \mathrm{E}+04$ & 0.00 \\
\hline \hline
\end{tabular}


Table A-2. Additional Anion Exchange Operating Data

\begin{tabular}{|l|c|c|c|}
\hline Feed Bottle & Volume (mL) & $\begin{array}{c}\text { Pu Height in } \\
\text { Column } \mathbf{( c m )}\end{array}$ & $\begin{array}{c}\text { Effluent Dose Rate } \\
\text { (mrem/h) }\end{array}$ \\
\hline Feed Items 1-3 & 2250 & 13 & 3 \\
\hline Feed Item 4.1 & 2000 & 18 & 65 \\
\hline Feed Item 4.2 & 2000 & 24 & 105 \\
\hline Feed Item 4.3 & 2000 & 29 & 120 \\
\hline Feed Item 4.4 & 2000 & 33 & 135 \\
\hline Feed Item 4.5 & 2000 & 38 & 135 \\
\hline Feed Item 4.6 & 2000 & 42 & 140 \\
\hline Feed Item 4.7 & 2000 & 46 & 130 \\
\hline Feed Item 4.8 & 900 & 46.5 & 90 \\
\hline Wash 1 & 1000 & NM & 110 \\
\hline Wash 2 & 2000 & 53 & 75 \\
\hline Wash 3 & 2000 & 55 & 16 \\
\hline Wash 4 & 2000 & 58 & 2.1 \\
\hline Wash 5 & 2000 & NM & 1.8 \\
\hline Wash 6 & 2000 & 59 & 1.5 \\
\hline Wash 7 & 2000 & NM & 1.2 \\
\hline Wash 8 & 2000 & 60 & 4.5 \\
\hline Heads & 1000 & NM & 48 \\
\hline Product & 1760 & NM & 4.8 \\
\hline Tails 1 & 1000 & NM & 2.5 \\
\hline Tails 2 & 1900 & NM & \\
\hline NM = not measured & & \\
\hline
\end{tabular}


Table A-3. Comparison of Primary Feed and Raffinate Contents by ICP-ES

\begin{tabular}{|c|c|c|}
\hline Element & $\begin{array}{c}\text { Feed Item } 4 \\
\text { (Primary Feed) } \\
(\mathrm{mg} / \mathrm{L})\end{array}$ & $\begin{array}{c}\text { Primary Feed } \\
\text { Raffinate } \\
(\mathrm{mg} / \mathrm{L})\end{array}$ \\
\hline $\mathrm{Al}$ & 4320 & 4540 \\
\hline B & 1110 & 1160 \\
\hline $\mathrm{Ba}$ & 1.83 & 1.61 \\
\hline $\mathrm{Be}$ & 1.93 & 2.12 \\
\hline $\mathrm{Ca}$ & 44.7 & 43.2 \\
\hline $\mathrm{Cd}$ & $<1.21$ & $<0.121$ \\
\hline $\mathrm{Ce}$ & $<7.91$ & 1.64 \\
\hline $\mathrm{Co}$ & $<1.83$ & 0.728 \\
\hline $\mathrm{Cr}$ & 42.2 & 44.4 \\
\hline $\mathrm{Cu}$ & 9.41 & 6.52 \\
\hline $\mathrm{Fe}$ & 1210 & 1250 \\
\hline $\mathrm{Gd}$ & $<3.84$ & $<1.92$ \\
\hline $\mathrm{K}$ & 1810 & 1880 \\
\hline $\mathrm{Mg}$ & 40.1 & 41.8 \\
\hline $\mathrm{Mn}$ & 7.1 & 8.01 \\
\hline Mo & $<16.4$ & 4.38 \\
\hline $\mathrm{Na}$ & 14300 & 14900 \\
\hline $\mathrm{Ni}$ & 95.4 & 98 \\
\hline $\mathrm{Pb}$ & $<17.6$ & 6.89 \\
\hline$S$ & $<300$ & $<30$ \\
\hline $\mathrm{Si}$ & $<21.5$ & 6.73 \\
\hline Sn & $<14.7$ & 5.89 \\
\hline $\mathrm{Sr}$ & $<0.2$ & 0.194 \\
\hline $\mathrm{Ti}$ & 1.29 & 1.74 \\
\hline $\mathrm{Zn}$ & 3.56 & 2.55 \\
\hline $\mathrm{Zr}$ & $<0.63$ & 0.747 \\
\hline
\end{tabular}


Table A-4. Comparison of Primary Feed and Raffinate Contents by ICP-MS

\begin{tabular}{|c|c|c|}
\hline $\begin{array}{c}\text { Mass } \\
\text { Number }\end{array}$ & $\begin{array}{c}\text { Feed Item } 4 \\
\text { (Primary Feed) } \\
(\mathrm{mg} / \mathrm{L})\end{array}$ & $\begin{array}{c}\text { Primary Feed } \\
\text { Raffinate } \\
\text { (mg/L) }\end{array}$ \\
\hline 59 & 0.774 & 0.76 \\
\hline 71 & 43.9 & 43.0 \\
\hline 88 & 0.209 & 0.15 \\
\hline 89 & 0.622 & 0.59 \\
\hline 90 & 0.661 & 0.46 \\
\hline 91 & 0.163 & 0.10 \\
\hline 92 & 0.955 & 0.77 \\
\hline 94 & 0.654 & 0.52 \\
\hline 95 & 0.752 & 0.69 \\
\hline 96 & 0.780 & 0.74 \\
\hline 97 & 0.445 & 0.45 \\
\hline 98 & 1.08 & 1.05 \\
\hline 100 & 0.478 & 0.44 \\
\hline 106 & $<0.200$ & $<0.02$ \\
\hline 107 & $<0.050$ & 0.01 \\
\hline 108 & $<0.050$ & $<0.015$ \\
\hline 110 & $<0.050$ & $<0.010$ \\
\hline 112 & 0.085 & 0.08 \\
\hline 114 & 0.105 & 0.06 \\
\hline 116 & 0.880 & 0.90 \\
\hline 117 & 0.429 & 0.47 \\
\hline 118 & 1.45 & 1.46 \\
\hline 119 & 1.03 & 0.53 \\
\hline 120 & 10.9 & 1.85 \\
\hline 121 & 0.103 & 0.12 \\
\hline 122 & 0.357 & 0.40 \\
\hline 123 & $<0.100$ & $<0.045$ \\
\hline 124 & 0.564 & 0.50 \\
\hline
\end{tabular}

Note: highlighted cells indicate values below the method detection limit 
Table A-5. Comparison of Primary Feed and Raffinate Contents by ICP-MS

\begin{tabular}{|c|c|c|}
\hline $\begin{array}{c}\text { Mass } \\
\text { Number }\end{array}$ & $\begin{array}{c}\text { Feed Item } 4 \\
\text { (Primary Feed) } \\
(\mathrm{mg} / \mathrm{L})\end{array}$ & $\begin{array}{c}\text { Primary Feed } \\
\text { Raffinate } \\
\text { (mg/L) }\end{array}$ \\
\hline 59 & 0.774 & 0.76 \\
\hline 71 & 43.9 & 43.0 \\
\hline 88 & 0.209 & 0.15 \\
\hline 89 & 0.622 & 0.59 \\
\hline 90 & 0.661 & 0.46 \\
\hline 91 & 0.163 & 0.10 \\
\hline 92 & 0.955 & 0.77 \\
\hline 94 & 0.654 & 0.52 \\
\hline 95 & 0.752 & 0.69 \\
\hline 96 & 0.780 & 0.74 \\
\hline 97 & 0.445 & 0.45 \\
\hline 98 & 1.08 & 1.05 \\
\hline 100 & 0.478 & 0.44 \\
\hline 106 & $<0.200$ & $<0.02$ \\
\hline 107 & $<0.050$ & 0.01 \\
\hline 108 & $<0.050$ & $<0.015$ \\
\hline 110 & $<0.050$ & $<0.010$ \\
\hline 112 & 0.085 & 0.08 \\
\hline 114 & 0.105 & 0.06 \\
\hline 116 & 0.880 & 0.90 \\
\hline 117 & 0.429 & 0.47 \\
\hline 118 & 1.45 & 1.46 \\
\hline 119 & 1.03 & 0.53 \\
\hline 120 & 10.9 & 1.85 \\
\hline 121 & 0.103 & 0.12 \\
\hline 122 & 0.357 & 0.40 \\
\hline 123 & $<0.100$ & $<0.045$ \\
\hline 124 & 0.564 & 0.50 \\
\hline 135 & 0.099 & 0.11 \\
\hline 137 & 0.227 & 0.18 \\
\hline 138 & 1.253 & 1.19 \\
\hline 140 & 5.83 & 1.53 \\
\hline 142 & 0.777 & 0.19 \\
\hline 144 & 0.08 & $<0.01$ \\
\hline 146 & 0.05 & $<0.01$ \\
\hline 155 & $<0.050$ & 0.02 \\
\hline 156 & 0.099 & 0.05 \\
\hline 157 & $<0.050$ & 0.02 \\
\hline 158 & $<0.050$ & 0.04 \\
\hline 160 & $<0.050$ & 0.03 \\
\hline 166 & $<0.050$ & 0.04 \\
\hline 167 & $<0.050$ & 0.03 \\
\hline
\end{tabular}

Note: highlighted cells indicate values below the method detection limit 
Table A-4. Comparison of Primary Feed and Raffinate Contents by ICP-MS (continued)

\begin{tabular}{||c|c|c||}
\hline $\begin{array}{c}\text { Mass } \\
\text { Number }\end{array}$ & $\begin{array}{c}\text { Feed Item 4 } \\
\text { (Primary Feed) } \\
\text { (mg/L) }\end{array}$ & $\begin{array}{c}\text { Primary Feed } \\
\text { Raffinate } \\
\text { (mg/L) }\end{array}$ \\
\hline 168 & $<0.050$ & 0.03 \\
\hline 170 & $<0.050$ & 0.03 \\
\hline 176 & $<0.050$ & $<0.01$ \\
\hline 177 & $<0.050$ & $<0.01$ \\
\hline 178 & $<0.050$ & 0.01 \\
\hline 179 & $<0.050$ & $<0.01$ \\
\hline 180 & $<0.050$ & 0.02 \\
\hline 181 & 0.162 & 0.14 \\
\hline 182 & 0.851 & 0.85 \\
\hline 183 & 0.434 & 0.47 \\
\hline 184 & 1.05 & 1.00 \\
\hline 186 & 0.922 & 0.94 \\
\hline 206 & 0.861 & 0.99 \\
\hline 207 & 0.809 & 0.83 \\
\hline 208 & 2.05 & 1.94 \\
\hline 234 & 0.166 & 0.16 \\
\hline 235 & 6.04 & 5.61 \\
\hline 236 & 1.22 & 0.95 \\
\hline 237 & 0.621 & 0.06 \\
\hline 238 & 1.68 & 0.59 \\
\hline 239 & 4416 & 7.66 \\
\hline 240 & 283 & 0.46 \\
\hline 241 & 15.0 & 13.10 \\
\hline \hline
\end{tabular}

Note: highlighted cells indicate values below the method detection limit

Table A-6. Uncertainties in MS Moisture Contents

\begin{tabular}{|c|c|c|c|}
\hline \multirow{2}{*}{ Batch ID } & \multirow{2}{*}{$\begin{array}{c}\text { MS } \\
\text { Moisture } \\
\text { Content, } \\
\text { wt \% }\end{array}$} & \multicolumn{2}{|c|}{$\begin{array}{c}\text { 95\% Confidence } \\
\text { Interval }\end{array}$} \\
\hline & & $\begin{array}{l}\text { Lower } \\
\text { Bound }\end{array}$ & $\begin{array}{l}\text { Upper } \\
\text { Bound }\end{array}$ \\
\hline Demo 1a & 0.30 & 0.28 & 0.33 \\
\hline Demo 1b & 0.32 & 0.30 & 0.35 \\
\hline Demo $1 \mathrm{c}^{*}$ & $>0.42$ & 0.39 & 0.45 \\
\hline Demo 1d*, Argon, Room Temp. for $1 \mathrm{~h}$ & 0.26 & 0.25 & 0.28 \\
\hline Demo $1 \mathrm{e}^{*}$, Argon, $\sim 50^{\circ} \mathrm{C}$ for $1 \mathrm{~h}$ & 0.37 & 0.34 & 0.39 \\
\hline Demo 1f*, Argon, $\sim 93{ }^{\circ} \mathrm{C}$ for $1 \mathrm{~h}$ & 0.44 & 0.41 & 0.48 \\
\hline
\end{tabular}


SRNL-STI-2012-00422

Revision 0

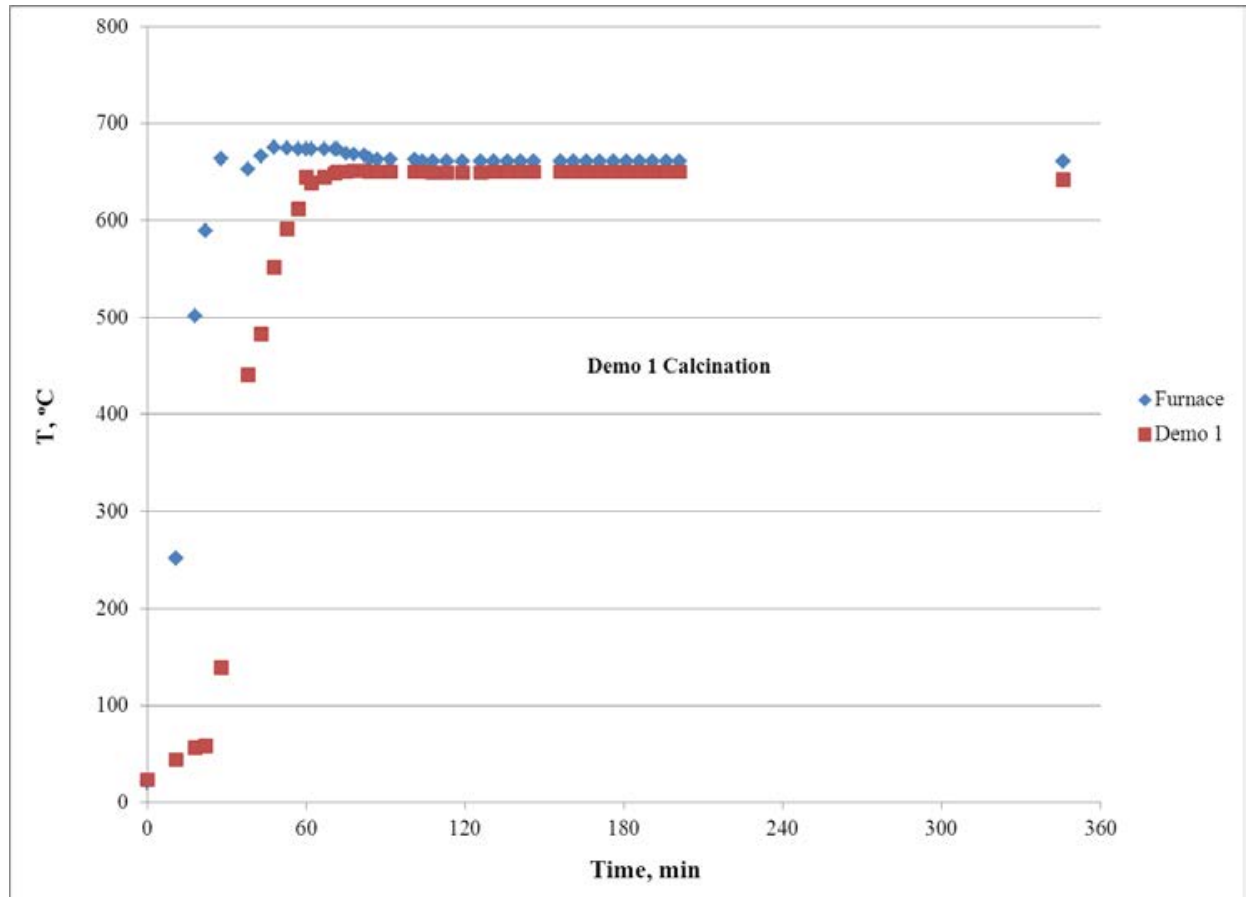

Figure A-1. Temperature Profiles for Demo 1 Calcination

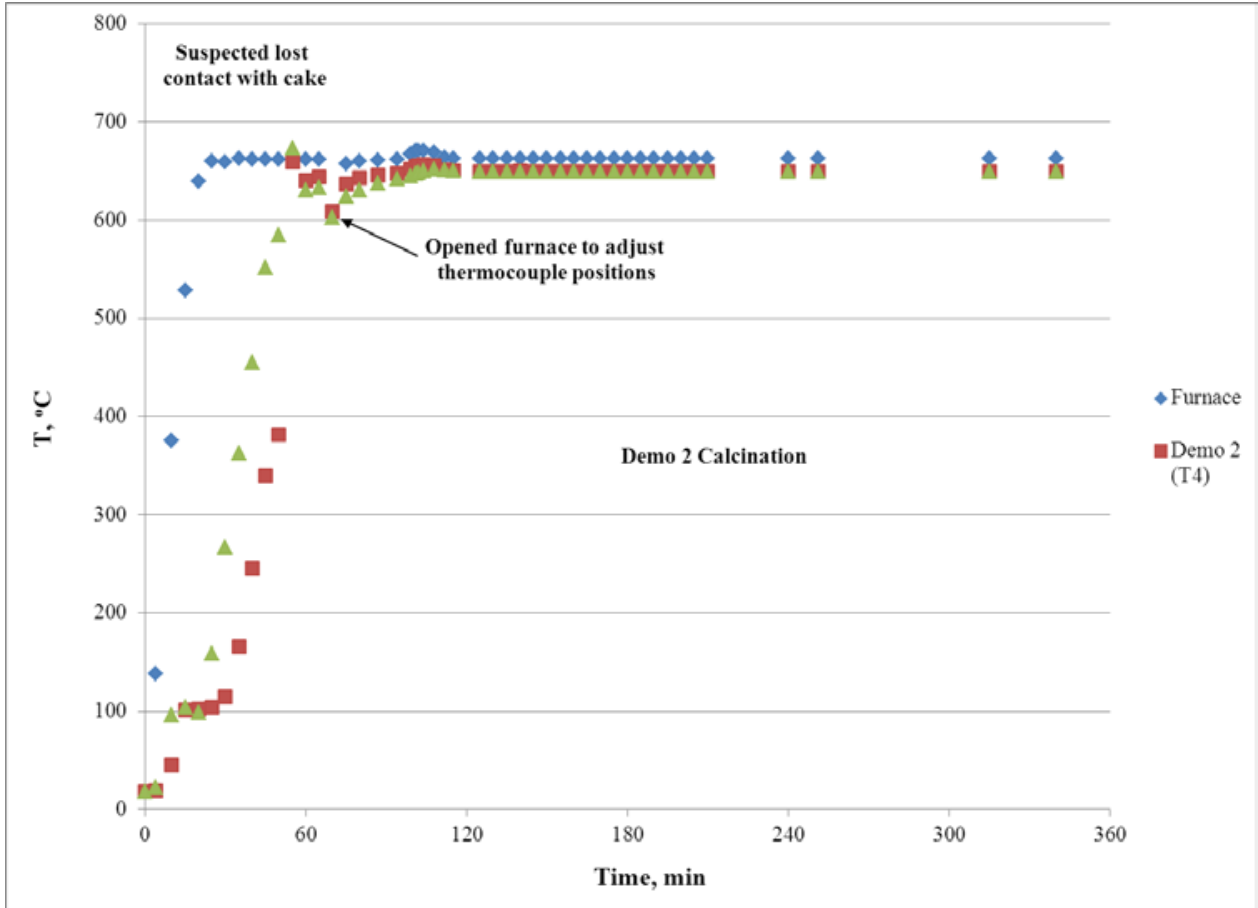

Figure A-2. Temperature Profiles for Demo 2 Calcination 


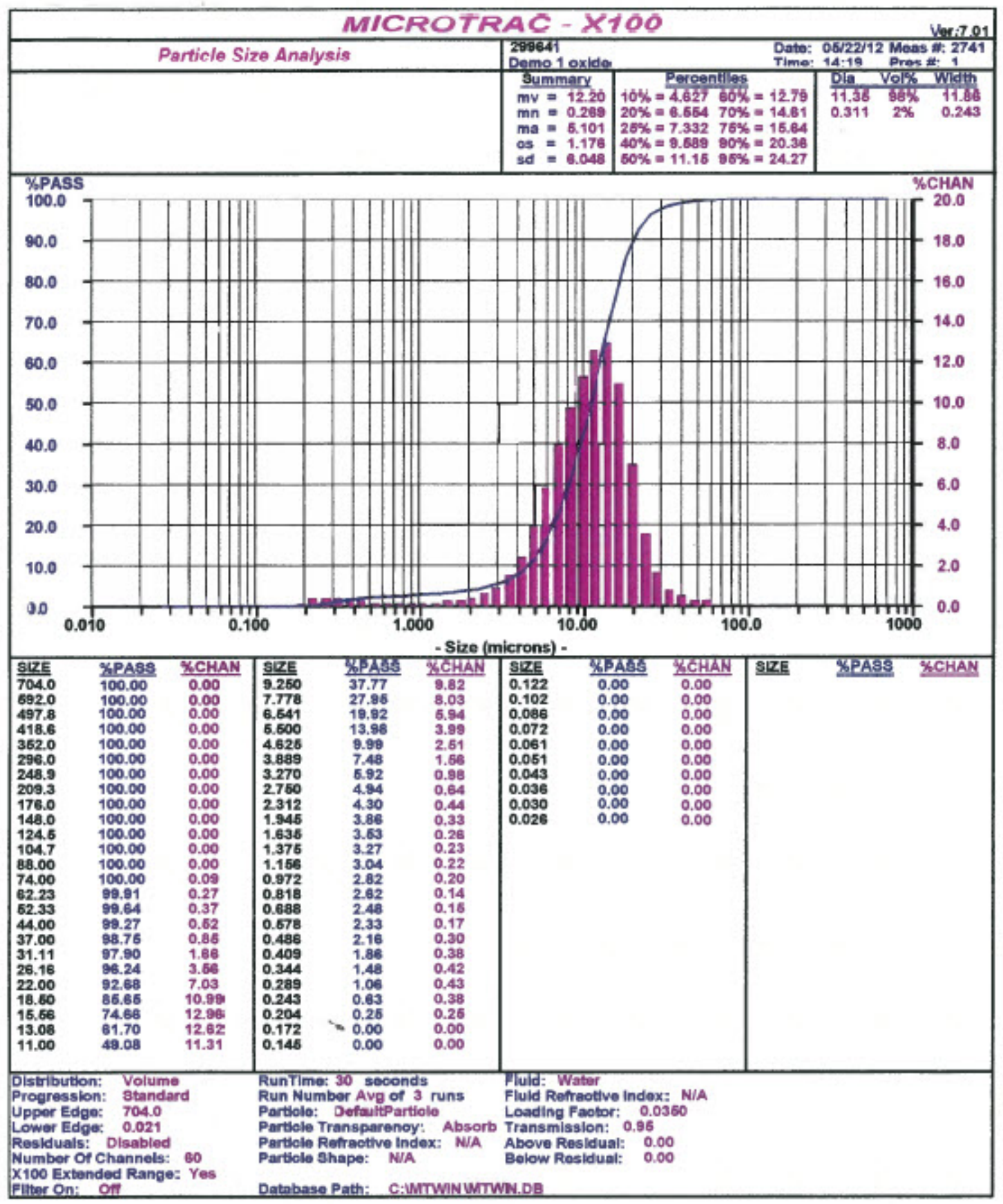

Figure A-3. Particle Size Analysis for Demo $1 \mathrm{PuO}_{2}$ 


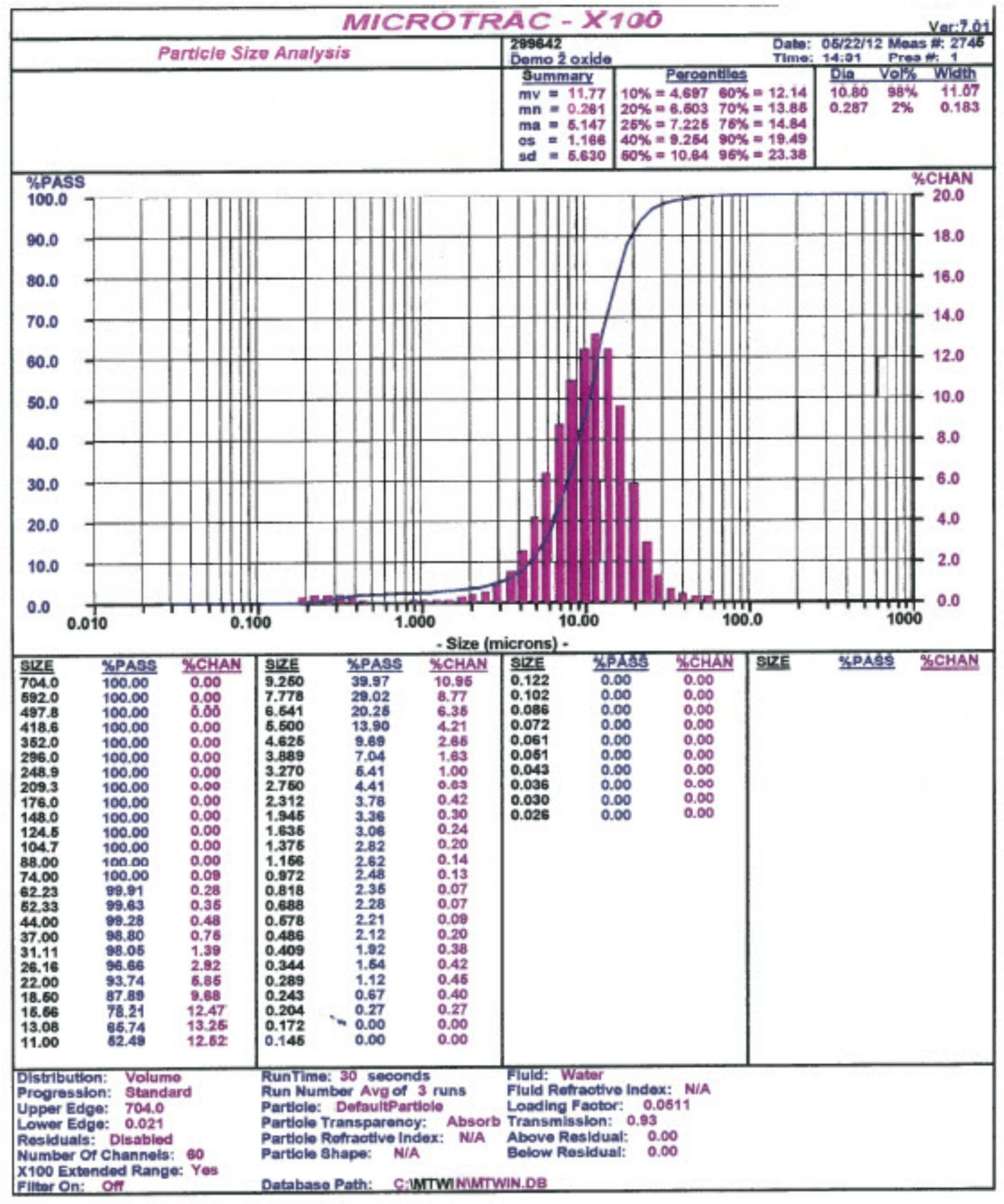

Figure A-4. Particle Size Analysis for Demo $2 \mathrm{PuO}_{2}$ 


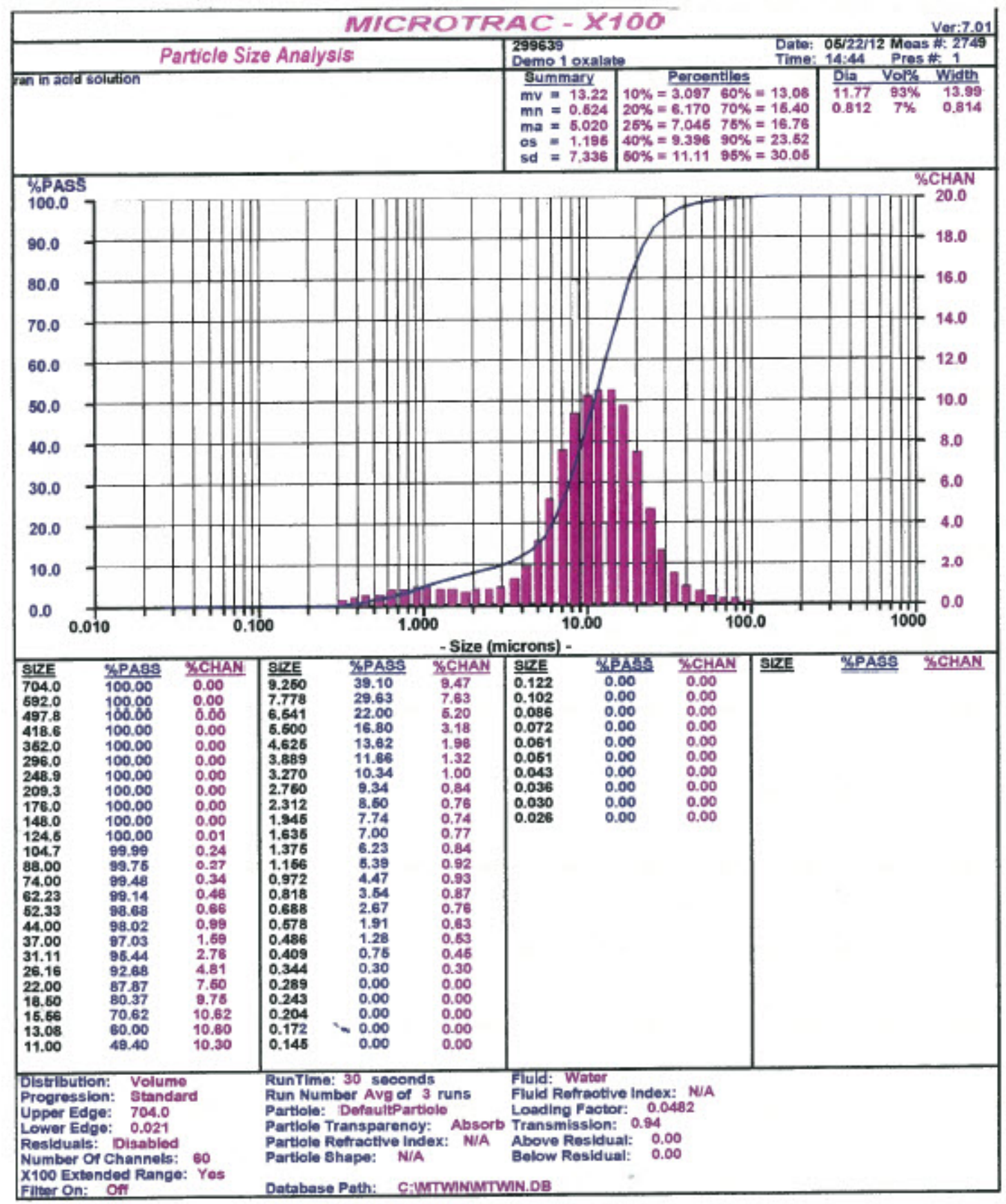

Figure A-5. Particle Size Analysis for Demo 1 Pu Oxalate 


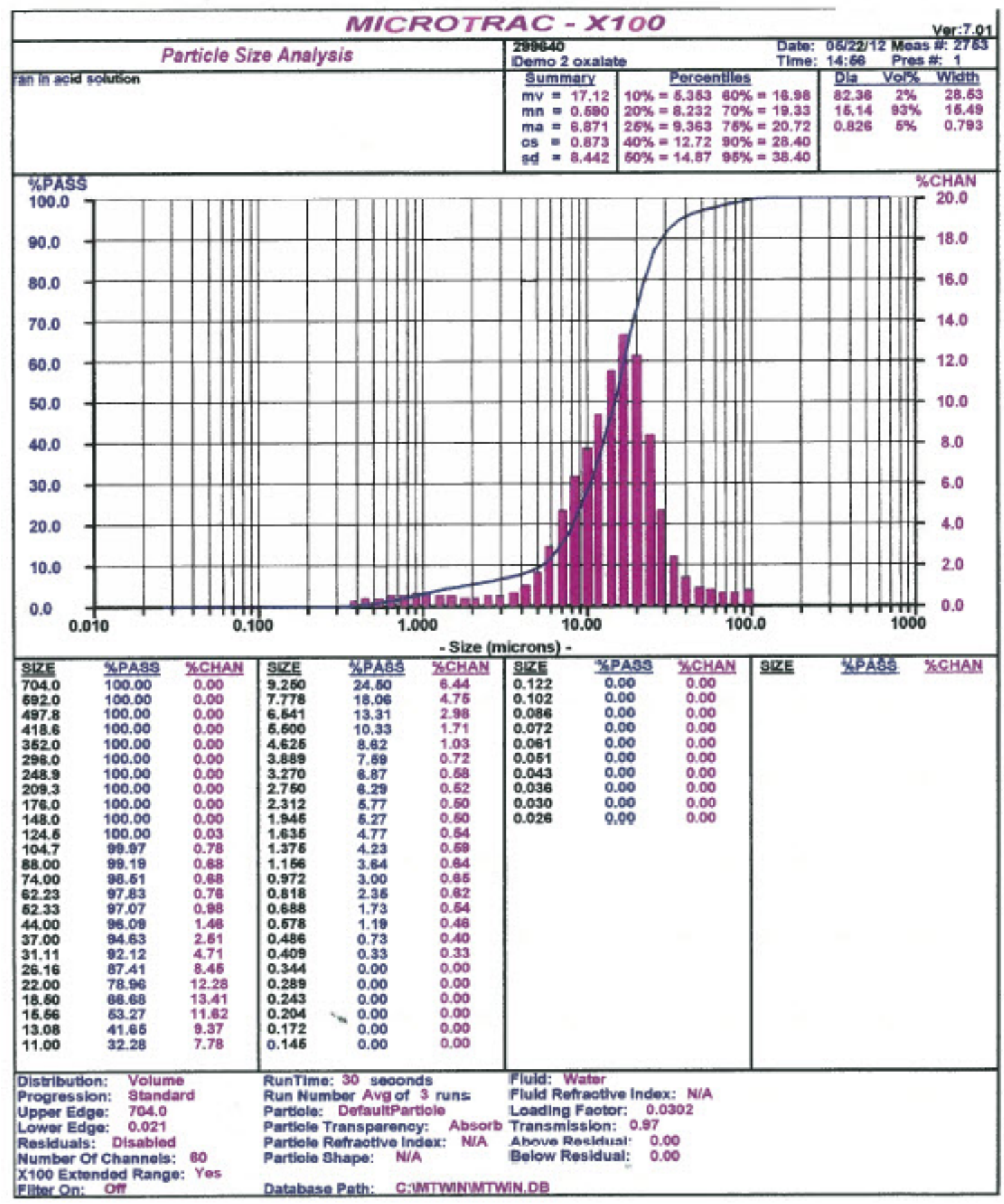

Figure A-6. Particle Size Analysis for Demo 2 Pu Oxalate 
Table A-7. Analyses of Reagents by ICP-ES and Total Acid

\begin{tabular}{|c|c|c|}
\hline Element & $\begin{array}{c}7 \text { M Nitric Acid } \\
(\mathrm{mg} / \mathrm{L})\end{array}$ & $\begin{array}{c}0.9 \text { M Oxalic Acid } \\
(\mathrm{mg} / \mathrm{L})\end{array}$ \\
\hline $\mathrm{Ag}$ & $<0.106$ & $<0.106$ \\
\hline Al & $<0.546$ & $<0.546$ \\
\hline$B$ & $<0.343$ & $<0.343$ \\
\hline $\mathrm{Ba}$ & $<0.028$ & $<0.028$ \\
\hline $\mathrm{Ca}$ & $<0.315$ & $<0.315$ \\
\hline $\mathrm{Cd}$ & $<0.054$ & $<0.054$ \\
\hline $\mathrm{Ce}$ & $<0.585$ & $<0.585$ \\
\hline $\mathrm{Co}$ & $<0.129$ & $<0.129$ \\
\hline $\mathrm{Cr}$ & $<0.067$ & $<0.067$ \\
\hline $\mathrm{Cu}$ & $<0.124$ & $<0.098$ \\
\hline $\mathrm{Fe}$ & $<0.114$ & 0.0846 \\
\hline $\bar{K}$ & $<2.43$ & $<2.43$ \\
\hline $\mathrm{La}$ & $<0.135$ & $<0.135$ \\
\hline $\mathrm{Li}$ & $<0.057$ & $<0.057$ \\
\hline $\mathrm{Mg}$ & $<0.254$ & $<0.254$ \\
\hline $\mathrm{Mn}$ & $<0.019$ & $<0.019$ \\
\hline Mo & $<0.162$ & $<0.162$ \\
\hline $\mathrm{Na}$ & $<0.56$ & $<0.56$ \\
\hline $\mathrm{Nb}$ & $<0.119$ & $<0.119$ \\
\hline $\mathrm{Nd}$ & $<0.61$ & $<0.61$ \\
\hline $\mathrm{Ni}$ & $<0.043$ & $<0.043$ \\
\hline$P$ & $<0.183$ & $<0.183$ \\
\hline $\mathrm{Pb}$ & $<0.23$ & $<0.23$ \\
\hline $\mathrm{Re}$ & $<4.06$ & $<0.811$ \\
\hline$S$ & $<0.735$ & $<0.735$ \\
\hline Si & $<0.206$ & $<0.206$ \\
\hline $\mathrm{Sn}$ & $<0.236$ & $<0.236$ \\
\hline $\mathrm{Sr}$ & $<0.008$ & $<0.008$ \\
\hline $\mathrm{Ti}$ & $<0.048$ & $<0.048$ \\
\hline $\mathrm{V}$ & $<0.043$ & $<0.043$ \\
\hline $\mathrm{Zn}$ & $<0.083$ & $<0.083$ \\
\hline $\mathrm{Zr}$ & $<0.043$ & $<0.043$ \\
\hline $\begin{array}{c}\text { Total } \\
\text { Acid, } \mathrm{M}\end{array}$ & 7.04 & NM \\
\hline
\end{tabular}

Note: highlighted cells indicate values above the method detection limit. $\mathrm{NM}=$ Not Measured 
SRNL-STI-2012-00422

Revision 0

Table A-8. Analyses of Reagents by ICP-MS

\begin{tabular}{|c|c|c|}
\hline $\begin{array}{c}\text { Mass } \\
\text { Number }\end{array}$ & $\begin{array}{c}7 \text { M Nitric } \\
\text { Acid } \\
(\mu \mathrm{g} / \mathrm{L}) \\
\end{array}$ & $\begin{array}{c}0.9 \text { M Oxalic } \\
\text { Acid } \\
(\mathrm{mg} / \mathrm{L})\end{array}$ \\
\hline 51 & $<5.00 \mathrm{E}-01$ & $<1.50 \mathrm{E}+00$ \\
\hline 59 & $<3.50 \mathrm{E}-01$ & $<2.00 \mathrm{E}-01$ \\
\hline 69 & $<1.00 \mathrm{E}-01$ & $<1.50 \mathrm{E}-01$ \\
\hline 71 & $<1.50 \mathrm{E}-01$ & $<1.00 \mathrm{E}-01$ \\
\hline 82 & $<8.55 \mathrm{E}+00$ & $<1.86 \mathrm{E}+01$ \\
\hline 84 & $<1.60 \mathrm{E}+00$ & $<3.95 \mathrm{E}+00$ \\
\hline 85 & $<5.50 \mathrm{E}-01$ & $<1.00 \mathrm{E}-01$ \\
\hline 86 & $<4.00 \mathrm{E}-01$ & $<4.00 \mathrm{E}-01$ \\
\hline 87 & $<1.00 \mathrm{E}-01$ & $<3.00 \mathrm{E}-01$ \\
\hline 88 & $<2.00 \mathrm{E}-01$ & $<1.00 \mathrm{E}-01$ \\
\hline 89 & $<1.50 \mathrm{E}-01$ & $<1.00 \mathrm{E}-01$ \\
\hline 90 & $<2.50 \mathrm{E}-01$ & $<1.00 \mathrm{E}-01$ \\
\hline 91 & $<1.00 \mathrm{E}-01$ & $<2.00 \mathrm{E}-01$ \\
\hline 92 & $<1.00 \mathrm{E}-01$ & $<4.00 \mathrm{E}-01$ \\
\hline 93 & $<1.00 \mathrm{E}-01$ & 7.45E-01 \\
\hline 94 & $<6.00 \mathrm{E}-01$ & $<2.00 \mathrm{E}-01$ \\
\hline 95 & $<3.00 \mathrm{E}-01$ & $<3.00 \mathrm{E}-01$ \\
\hline 96 & $<4.50 \mathrm{E}-01$ & $<3.00 \mathrm{E}-01$ \\
\hline 97 & $<4.50 \mathrm{E}-01$ & $<2.00 \mathrm{E}-01$ \\
\hline 98 & $<1.50 \mathrm{E}-01$ & $<4.00 \mathrm{E}-01$ \\
\hline 99 & $<1.50 \mathrm{E}-01$ & $<1.50 \mathrm{E}-01$ \\
\hline 100 & $<1.50 \mathrm{E}-01$ & $<2.00 \mathrm{E}-01$ \\
\hline 101 & $<1.00 \mathrm{E}-01$ & $<1.50 \mathrm{E}-01$ \\
\hline 102 & $<2.00 \mathrm{E}-01$ & $<2.50 \mathrm{E}-01$ \\
\hline 103 & $<1.00 \mathrm{E}-01$ & $<2.00 \mathrm{E}-01$ \\
\hline 104 & $<1.00 \mathrm{E}-01$ & $<1.00 \mathrm{E}-01$ \\
\hline 105 & $<1.00 \mathrm{E}-01$ & $<1.50 \mathrm{E}-01$ \\
\hline 106 & $<1.00 \mathrm{E}-01$ & $<1.00 \mathrm{E}-01$ \\
\hline 107 & $<1.50 \mathrm{E}-01$ & $<1.50 \mathrm{E}-01$ \\
\hline 108 & $<1.50 \mathrm{E}-01$ & $<1.50 \mathrm{E}-01$ \\
\hline 109 & $<1.00 \mathrm{E}-01$ & $<2.00 \mathrm{E}-01$ \\
\hline 110 & $<1.00 \mathrm{E}-01$ & $<2.50 \mathrm{E}-01$ \\
\hline 111 & $<2.50 \mathrm{E}-01$ & $<1.00 \mathrm{E}-01$ \\
\hline 112 & $<2.00 \mathrm{E}-01$ & $<1.50 \mathrm{E}-01$ \\
\hline 113 & $<2.65 \mathrm{E}+00$ & $<2.60 \mathrm{E}+00$ \\
\hline 114 & $<2.50 \mathrm{E}-01$ & $<1.00 \mathrm{E}-01$ \\
\hline 116 & 1.67E-01 & $<1.00 \mathrm{E}-01$ \\
\hline 117 & 1.05E-01 & $<1.00 \mathrm{E}-01$ \\
\hline 118 & 2.55E-01 & $<1.00 \mathrm{E}-01$ \\
\hline 119 & $<1.50 \mathrm{E}-01$ & $<2.00 \mathrm{E}-01$ \\
\hline 120 & 3.09E-01 & $<2.00 \mathrm{E}-01$ \\
\hline 121 & $<2.50 \mathrm{E}-01$ & $<1.00 \mathrm{E}-01$ \\
\hline 122 & $<2.50 \mathrm{E}-01$ & $<1.00 \mathrm{E}-01$ \\
\hline 123 & $<1.50 \mathrm{E}-01$ & $<1.00 \mathrm{E}-01$ \\
\hline
\end{tabular}


SRNL-STI-2012-00422

Revision 0

Table A-7. Analyses of Reagents by ICP-MS (continued)

\begin{tabular}{|c|c|c|}
\hline $\begin{array}{c}\text { Mass } \\
\text { Number }\end{array}$ & $\begin{array}{c}7 \text { M Nitric } \\
\text { Acid } \\
(\mu \mathrm{g} / \mathrm{L})\end{array}$ & $\begin{array}{c}0.9 \text { M Oxalic Acid } \\
\text { (mg/L) }\end{array}$ \\
\hline 124 & $<2.50 \mathrm{E}-01$ & $<2.50 \mathrm{E}-01$ \\
\hline 125 & $<$ 5.50E-01 & $<1.50 \mathrm{E}-01$ \\
\hline 126 & $<5.50 \mathrm{E}-01$ & $<5.00 \mathrm{E}-01$ \\
\hline 128 & $<7.00 \mathrm{E}-01$ & $<1.50 \mathrm{E}+00$ \\
\hline 130 & $<2.90 \mathrm{E}+00$ & $<6.50 \mathrm{E}-01$ \\
\hline 133 & $<5.00 \mathrm{E}-01$ & $<2.50 \mathrm{E}-01$ \\
\hline 134 & $<2.00 \mathrm{E}-01$ & $<3.40 \mathrm{E}+00$ \\
\hline 135 & $<1.50 \mathrm{E}-01$ & $<1.00 \mathrm{E}-01$ \\
\hline 136 & $<6.50 \mathrm{E}-01$ & $<1.05 \mathrm{E}+00$ \\
\hline 137 & $<1.00 \mathrm{E}-01$ & $<1.00 \mathrm{E}-01$ \\
\hline 138 & $<1.00 \mathrm{E}-01$ & $<1.00 \mathrm{E}-01$ \\
\hline 139 & $<1.00 \mathrm{E}-01$ & $<1.00 \mathrm{E}-01$ \\
\hline 140 & $1.87 \mathrm{E}-01$ & $1.20 \mathrm{E}+00$ \\
\hline 141 & $<2.00 \mathrm{E}-01$ & $<1.00 \mathrm{E}-01$ \\
\hline 142 & $<1.00 \mathrm{E}-01$ & $<2.00 \mathrm{E}-01$ \\
\hline 143 & $<1.00 \mathrm{E}-01$ & $<1.00 \mathrm{E}-01$ \\
\hline 144 & $<1.00 \mathrm{E}-01$ & $<1.00 \mathrm{E}-01$ \\
\hline 145 & $<1.00 \mathrm{E}-01$ & $<1.00 \mathrm{E}-01$ \\
\hline 146 & $<1.00 \mathrm{E}-01$ & $<1.00 \mathrm{E}-01$ \\
\hline 147 & $<1.00 \mathrm{E}-01$ & $<1.00 \mathrm{E}-01$ \\
\hline 148 & $<1.00 \mathrm{E}-01$ & $<1.00 \mathrm{E}-01$ \\
\hline 149 & $<1.00 \mathrm{E}-01$ & $<1.00 \mathrm{E}-01$ \\
\hline 150 & $<1.50 \mathrm{E}-01$ & $<1.00 \mathrm{E}-01$ \\
\hline 151 & $<1.00 \mathrm{E}-01$ & $<1.00 \mathrm{E}-01$ \\
\hline 152 & $<1.00 \mathrm{E}-01$ & $<1.00 \mathrm{E}-01$ \\
\hline 153 & $<1.00 \mathrm{E}-01$ & $<1.00 \mathrm{E}-01$ \\
\hline 154 & $<1.00 \mathrm{E}-01$ & $<1.00 \mathrm{E}-01$ \\
\hline 155 & $<1.50 \mathrm{E}-01$ & $<1.00 \mathrm{E}-01$ \\
\hline 156 & $<1.00 \mathrm{E}-01$ & $<1.00 \mathrm{E}-01$ \\
\hline 157 & $<1.00 \mathrm{E}-01$ & $<1.00 \mathrm{E}-01$ \\
\hline 158 & $<1.00 \mathrm{E}-01$ & $<1.00 \mathrm{E}-01$ \\
\hline 159 & $<2.00 \mathrm{E}-01$ & $<1.00 \mathrm{E}-01$ \\
\hline 160 & $<1.00 \mathrm{E}-01$ & $<1.00 \mathrm{E}-01$ \\
\hline 161 & $<1.00 \mathrm{E}-01$ & $<1.00 \mathrm{E}-01$ \\
\hline 162 & $<1.00 \mathrm{E}-01$ & $<2.00 \mathrm{E}-01$ \\
\hline 163 & $<1.00 \mathrm{E}-01$ & $<1.00 \mathrm{E}-01$ \\
\hline 164 & $<1.00 \mathrm{E}-01$ & $<1.50 \mathrm{E}-01$ \\
\hline 165 & $<1.00 \mathrm{E}-01$ & $<1.00 \mathrm{E}-01$ \\
\hline 166 & $<1.00 \mathrm{E}-01$ & $<1.00 \mathrm{E}-01$ \\
\hline
\end{tabular}


SRNL-STI-2012-00422

Revision 0

Table A-7. Analyses of Reagents by ICP-MS (continued)

\begin{tabular}{|c|c|c|}
\hline $\begin{array}{c}\text { Mass } \\
\text { Number }\end{array}$ & $\begin{array}{c}\text { M Nitric } \\
\text { Acid } \\
(\mu \mathrm{g} / \mathrm{L})\end{array}$ & $\begin{array}{c}0.9 \text { M Oxalic Acid } \\
(\mathrm{mg} / \mathrm{L})\end{array}$ \\
\hline 167 & $<1.00 \mathrm{E}-01$ & $<1.00 \mathrm{E}-01$ \\
\hline 168 & $<1.00 \mathrm{E}-01$ & $<1.00 \mathrm{E}-01$ \\
\hline 169 & $<1.00 \mathrm{E}-01$ & $<1.00 \mathrm{E}-01$ \\
\hline 170 & $<1.00 \mathrm{E}-01$ & $<1.00 \mathrm{E}-01$ \\
\hline 171 & $<1.00 \mathrm{E}-01$ & $<1.00 \mathrm{E}-01$ \\
\hline 172 & $<1.00 \mathrm{E}-01$ & $<1.00 \mathrm{E}-01$ \\
\hline 173 & $<1.00 \mathrm{E}-01$ & $<1.00 \mathrm{E}-01$ \\
\hline 174 & $<1.00 \mathrm{E}-01$ & $<1.00 \mathrm{E}-01$ \\
\hline 175 & $<1.00 \mathrm{E}-01$ & $<1.00 \mathrm{E}-01$ \\
\hline 176 & $<1.00 \mathrm{E}-01$ & $<1.00 \mathrm{E}-01$ \\
\hline 177 & $<1.00 \mathrm{E}-01$ & $<1.00 \mathrm{E}-01$ \\
\hline 178 & $<1.00 \mathrm{E}-01$ & $<1.00 \mathrm{E}-01$ \\
\hline 179 & $<1.00 \mathrm{E}-01$ & $<1.00 \mathrm{E}-01$ \\
\hline 180 & $<1.00 \mathrm{E}-01$ & $<1.50 \mathrm{E}-01$ \\
\hline 181 & $<1.00 \mathrm{E}-01$ & $2.10 \mathrm{E}+00$ \\
\hline 182 & $<1.00 \mathrm{E}-01$ & $<1.00 \mathrm{E}-01$ \\
\hline 183 & $<1.00 \mathrm{E}-01$ & $<1.00 \mathrm{E}-01$ \\
\hline 184 & $<1.00 \mathrm{E}-01$ & $<1.00 \mathrm{E}-01$ \\
\hline 185 & $<1.00 \mathrm{E}-01$ & $<1.00 \mathrm{E}-01$ \\
\hline 186 & $<1.00 \mathrm{E}-01$ & $<1.00 \mathrm{E}-01$ \\
\hline 187 & $<1.00 \mathrm{E}-01$ & $<1.00 \mathrm{E}-01$ \\
\hline 191 & $1.72 \mathrm{E}-01$ & $<3.00 \mathrm{E}-01$ \\
\hline 193 & 1.90E-01 & $<3.00 \mathrm{E}-01$ \\
\hline 194 & $<3.00 \mathrm{E}-01$ & $<1.50 \mathrm{E}-01$ \\
\hline 195 & $<1.50 \mathrm{E}-01$ & $<2.50 \mathrm{E}-01$ \\
\hline 196 & $<1.50 \mathrm{E}-01$ & $<1.00 \mathrm{E}-01$ \\
\hline 197 & $<6.00 \mathrm{E}-01$ & $<7.00 \mathrm{E}-01$ \\
\hline 198 & $<1.00 \mathrm{E}-01$ & $<1.00 \mathrm{E}-01$ \\
\hline 203 & $<2.00 \mathrm{E}-01$ & $<1.00 \mathrm{E}-01$ \\
\hline 204 & $<1.00 \mathrm{E}-01$ & $<1.00 \mathrm{E}-01$ \\
\hline 205 & $<5.00 \mathrm{E}-01$ & $<1.00 \mathrm{E}-01$ \\
\hline 206 & 1.97E-01 & $<1.50 \mathrm{E}-01$ \\
\hline 207 & $1.81 \mathrm{E}-01$ & $<1.50 \mathrm{E}-01$ \\
\hline 208 & 4.09E-01 & $<2.00 \mathrm{E}-01$ \\
\hline 232 & $<1.50 \mathrm{E}-01$ & $<1.00 \mathrm{E}-01$ \\
\hline 235 & $<2.00 \mathrm{E}-01$ & $<1.00 \mathrm{E}-01$ \\
\hline 238 & $4.71 \mathrm{E}+00$ & $<2.00 \mathrm{E}-01$ \\
\hline
\end{tabular}




\section{Distribution:}

S. D. Fink, 773-A

K. M. Fox, 999-W

B. J. Giddings, 786-5A

C. C. Herman, 999-W

S. L. Marra, 773-A

F. M. Pennebaker, 773-42A

W. R. Wilmarth, 773-A

E. A. Kyser, 773-A

T. S. Rudisill, 773-A

R. A. Pierce, 773-A

J. H. Scogin, 773-A

M. C. Thompson, 773-A

W. D. King, 773-42A

C. A. Nash, 773-42A

M. L. Crowder, 773-A

K. M. L. Taylor-Pashow, 773-A

S. L. Garrison, 704-2H

Records Administration (EDWS)

C. Wilson, 773-A
W. E. Harris, 704-2H

J. B. Schaade, 704-2H

G. J. Zachman, 225-7H

P. B. Andrews, 704-2H

S. J. Howell, 221-H

W. G. Dyer, 704-2H

M. J. Swain, 703-H

M. J. Lewczyk, 221-H

J. L. O’Conner, 704-2H

S. L. Hudlow, 221-H

W. H. Clifton, 704-2H

K. P. Burrows, 704-2H

K. J. Gallahue, 221-H

J. E. Therrell, 704-2H

J. W. Christopher, 704-2H

J. E. Elkourie, 704-2H

R. H. Smith, 704-2H

R. R. Livingston, 730-2B

D. Stimac, 730-2B

J. W. McClard, 705-K

S. A. Thomas, 703-46A 